ROGÉRIO FERNANDO TAFFARELLO

\title{
DROGAS: FALÊNCIA DO PROIBICIONISMO E ALTERNATIVAS DE POLÍTICA CRIMINAL
}

\author{
DISSERTAÇÃO DE MESTRADO \\ ORIENTADOR: PROF. TITULAR MIGUEL REALE JUNIOR
}

UNIVERSIDADE DE SÃO PAULO

FACULDADE DE DIREITO

SÃO PAULO, 2009 
ROGÉRIO FERNANDO TAFFARELLO

DROGAS: FALÊNCIA DO PROIBICIONISMO E ALTERNATIVAS DE POLÍTICA CRIMINAL

Dissertação apresentada ao Departamento de Direito Penal, Criminologia e Medicina Forense da Faculdade de Direito da Universidade de São Paulo para a obtenção do título de mestre em direito.

Área de concentração: direito penal e criminologia.

Orientador: Prof. Titular Miguel Reale Junior

SÃO PAULO 


Taffarello Rogério Fernando
Drogas : falência do proibicionismo e alternativas de política
criminal / Rogério Fernando Taffarello. - São Paulo : R. F. Taffarello,
2009.
153 p. ; $30 \mathrm{~cm}$.
Dissertação (Mestrado) - Faculdade de Direito da USP, 2009.
Orientador: Prof. Titular Miguel Reale Jr.
Notas de rodapé
Inclui bibliografia.
443.575(091)(043)
1. Drogas de abuso 2. Direito penal 3. Criminologia criminal 5 História I. Título.




\section{Resumo}

TAFFARELLO, R. F. Drogas: falência do proibicionismo e alternativas de política criminal. 2009. 155p. Dissertação (mestrado em direito) - Faculdade de Direito, Universidade de São Paulo.

O presente trabalho analisa a evolução das relações entre drogas e seres humanos e seu estatuto jurídico, com ênfase na emergência do modelo político proibicionista durante o século XX. Critica a imposição desse modelo ao mundo, por sua ilegitimidade mesma e por suas desastrosas conseqüências jurídicas e sociais. $\mathrm{Na}$ busca de uma alternativa ao proibicionismo, examina modelos políticos e textos legislativos de países mais avançados na matéria, a fim de sugerir um novo paradigma jurídico e político de regulação de drogas ao Brasil.

Palavras-chave: Drogas. Direito Penal. Criminologia. Política Criminal. História.

\section{Sintesi}

TAFFARELLO, R. F. Sulle Drogue: fallimento del proibizionismo ed alternative di politica criminale. 2009. 155p. Dissertação (mestrado em direito) - Faculdade de Direito, Universidade de São Paulo.

Il presente lavoro analizza l'evoluzione delle relazioni tralle drogue ed esseri umani ed il suo statuto legale, con enfasi sulo sviluppo del modello politico proibizionista durante il Novecento. Il lavoro critica l'imposizione di questo modello al mondo, per la sua illegitimità stessa e per le sue disastroese conseguenze giuridiche e sociali. In cerca di una alternativa al proibizionismo, discute modelli politici e texti legali di paesi più avanzati nel tema, affinché proponga un nuovo paradigma giuridico e politico di controllo di drogue al Brasile.

Parole chiavi: Drogue. Diritto Penale. Criminologia. Politica Criminale. Storia 


\section{LISTA DE ABREVIATURAS}

DEA - Drug Enforcement Administration

EUA - Estados Unidos da América

EMCDD - European Monitoring Centre for Drugs and Drug Addiction

FBN - Federal Bureau of Narcotics

OEDT - Observatório Europeu da Droga e da Toxicodependência

OMS - Organização Mundial de Saúde

ONU - Organização das Nações Unidas

MDMA - 3,4 metilenodioximetanfetamina (ecstasy)

NSDD - National Security Directive on Narcotics and National Security

THC - Tetrahidrocanabinol

UE - União Européia

UNDOC - United Nations Office on Drugs and Crime

WHO - World Health Organization 


\section{SUMÁRIO}

Introdução ...............................................................................................................

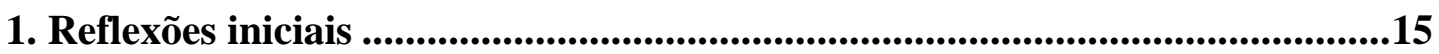

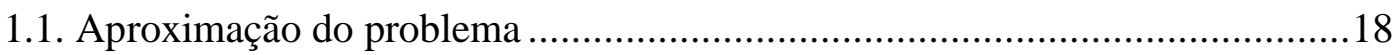

1.2 Sobre as drogas legais universais - o álcool e o tabaco....................................20

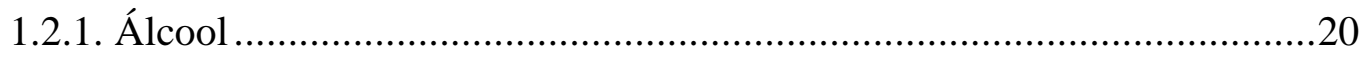

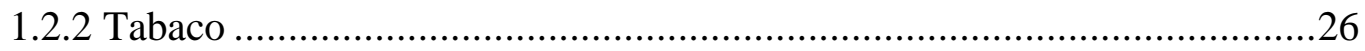

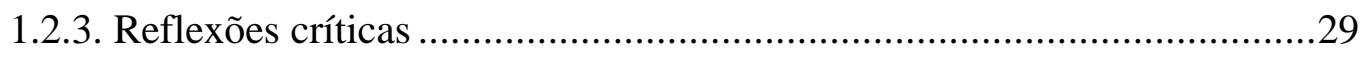

2. Análise histórica do consumo, da oferta e do tratamento legal..........................32

2.1. Antecedentes: da Antiguidade à modernidade .........................................32

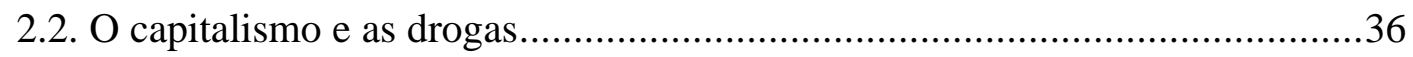

2.3. Século XX: disseminação do consumo e conseqüente crise social ....................38

2.4. O século XX e o influxo do proibicionismo ………………………………......44

2.4.1. Moralismo puritano e higienização social como fundamentos de

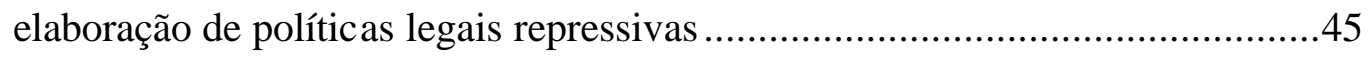

2.4.2. Da sanidade social às ideologias da segurança .......................................54

2.4.3. Anos 70: repressão de drogas como assunto de segurança nacional, e posterior exportação da guerra às drogas sob a forma de intervencionismo

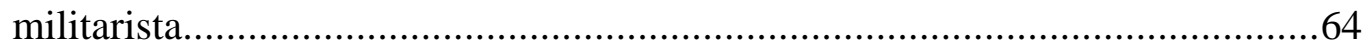

3. O Modelo legislativo positivo da repressão a drogas .............................................80

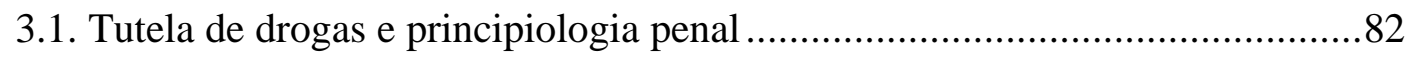

3.2. Algumas considerações de índole criminológica .............................................86

4. Liberdade individual versus paternalismo legal...................................................89

5. Ineficácia manifesta da criminalização do comércio de drogas antes os fins a que se propõe (o war on supply, o paradoxo dos lucros e o efeito hidra) ................95

6. Tendência alternativa emergente: $o$ atual tratamento da matéria na Europa100

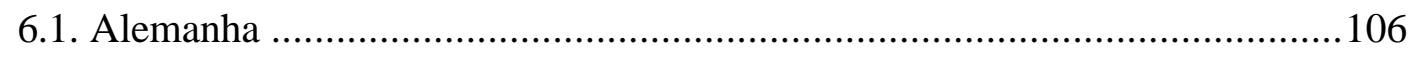

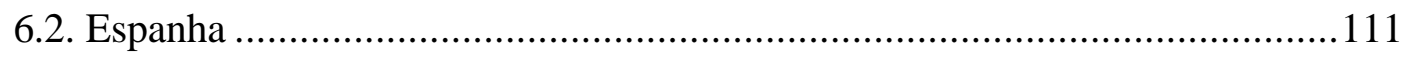

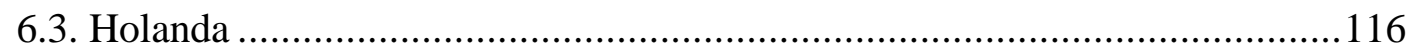

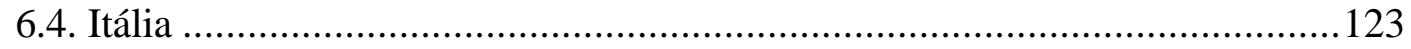




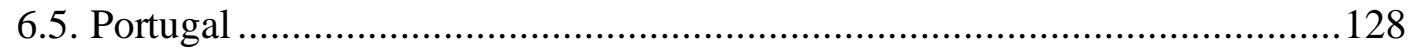

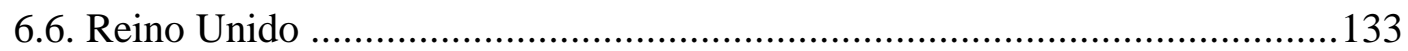

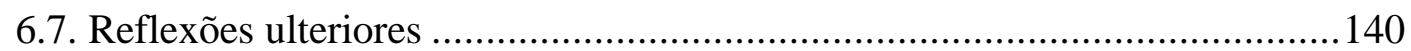

7. Reflexões conclusivas .............................................................................143

Bibliografia...................................................................................................................145 


\section{INTRODUÇÃO}

Entre os mais polêmicos objetos de tutela do direito penal figuram, já desde muito, as condutas relacionadas ao uso e ao comércio de substâncias psicoativas ilícitas. Considerável parcela da população mundial consome estas substâncias, regularmente ou não. Fazem-no pelas mais diversas razões, sejam elas culturais, medicinais, psicológicas, ou mesmo para fins meramente recreativos. E a sua utilização é notada desde a Antiguidade ${ }^{1}$, sendo muito pouco provável que, de lá para cá, o consumo de tais substâncias tenha deixado de ocorrer em algum momento da história.

Diversas definições há para o que se costuma chamar de drogas. A Organização Mundial de Saúde (OMS), anos atrás, manifestou-se pela impropriedade dos termos toxicomania, hábito e entorpecente, sugerindo a utilização de, respectivamente, dependência e drogas que produzem dependência ${ }^{2}$, o que, porém, mereceu críticas - a nosso ver inexatas - pelo fato de ser insuficiente para discernir entre drogas lícitas e ilícitas ${ }^{3}$. A farmacologia moderna, entretanto, desde meados do século XX recomenda o uso da terminologia sicoativos $^{4}$, que preferiremos utilizar nestas páginas, embora sem necessariamente excluir o recurso aos demais vocábulos ${ }^{5}$

\footnotetext{
${ }^{1}$ Vide infra, cap. 4. Ilustrativamente, mencione-se a observação do pioneiro farmacologista alemão Ludwig Lewin, o qual, no século XIX, referindo-se às drogas, assinalou que "com a única exceção dos alimentos, não existe na Terra substâncias que estejam tão intimamente associadas com as vidas dos povos e em todos os tempos". Apud CARNEIRO, Henrique. "A Odisséia psiconáutica: a história de um século e meio de pesquisas sobre plantas e substâncias psicoativas". In: LABATE, Beatriz Caiuby; GOULART, Sandra Lucia (orgs.). O Uso ritual das plantas de poder. Campinas: Mercado de Letras, 2005, p. 57.

2 A respeito, vide: GRECO FILHO, Vicente. Tóxicos: prevenção - repressão, $11^{\mathrm{a}}$ ed. São Paulo: Saraiva, 1996, p. 04.

${ }^{3}$ Cremos que tal se deva simplesmente ao fato de não haver como diferenciá-las por sua natureza, mas apenas pelo critério arbitrário do tratamento legal a elas dispensado, o que, a nosso ver, eximiria a OMS de uma suposta necessidade de discernir entre umas e outras.

${ }^{4}$ GOULART, Sandra Lucia et al. "Introdução". In: LABATE, Beatriz Caiuby; GOULART, Sandra Lucia (orgs.). Op. cit., p. 30. Atualmente, a própria Organização Mundial de Saúde consagra correspondente conceituação: "substâncias psicoativas são aquelas que, quando consumidas ou administradas ao organismo, afetam processos mentais como cognição ou sentimentos. Essa expressão e sua equivalente, droga psicotrópica, são os mais neutros e descritivos termos para toda a classe de substâncias lícitas e ilícitas de interesse das políticas sobre drogas". Disponível em: $<$ http://www.who.int/substance_abuse/terminology/psychoactive_substances/en/index.html >. Acesso em 10/01/2008.

5 Evitaremos, entretanto, a utilização do vocábulo tóxico, ou mesmo substâncias tóxicas, porquanto sua designação semântica compreende somente um sentido negativo, o que vai de encontro a uma das premissas fundamentais desse trabalho: o mal que pode decorrer do uso de tais substâncias, antes de ser-lhes intrínseco, depende decisivamente da maneira como são administradas.
} 
- drogas, fármacos -, que aqui serão adotados como sinônimos com vistas a evitar repetições vocabulares inestéticas e enfadonhas.

Ademais, há muitas diferenças entre cada uma das substâncias que tais termos visam a abranger, e ainda muito se discute a respeito de terminologias e conceitos mais adequados. De modo geral, malgrado a sua notável heterogeneidade, podem-se dividir tais substâncias em três grandes grupos: o dos psicoanalépticos (excitantes), em que se incluem o grupo das anfetaminas e os estimulantes, como coca e cafeína; o dos psicolépticos (sedativos), que compreendem os tranqüilizantes, alcalóides e opiáceos - entre estes a heroína e a morfina; e o dos psicodislépticos (alteradores de consciência), também conhecidos como alucinógenos, em que se inserem, por exemplo, a maconha, a mescalina e o ácido lisérgico (LSD) ${ }^{6}$.

No Brasil, como em outros países, sempre foi notável um certo absenteísmo estatal ante a clara necessidade de se elaborar uma política pública própria; invariavelmente, o Estado brasileiro deixou-se levar pelas orientações no sentido da proibição penal absoluta advindas dos Estados Unidos da América e, a partir da segunda metade do século XX, também das Organizações das Nações Unidas. Com efeito, a mera importação de institutos jurídicos - como temos visto ocorrer com grande freqüência nos últimos anos em nosso direito material e processual - jamais poderá satisfazer plenamente a questão, na medida em que culturas diferentes reclamam soluções diferentes para atender às suas idiossincrasias. Soluções adequadas para alguns países podem não se adequar ao nosso, valendo o mesmo também no sentido contrário, daí a necessidade de estudarmos aqui, com a necessária independência, o referido tema.

É fato, outrossim, que o tema demanda extensas discussões científicas, necessariamente de cunho multidisciplinar - algo a que, cite-se, nem sempre o mundo jurídico se mostra acostumado. E, mesmo no campo do direito penal, faz-se imprescindível a consideração de aspectos da história, da criminologia, da antropologia e da sociologia para que se possa chegar a uma discussão em níveis adequados - sem significar qualquer desprezo à dogmática jurídico-penal, que, todavia, remanesce inidônea para tratar da questão sem o recurso aos demais ramos

${ }^{6}$ GRECO FILHO, Vicente. Op. cit., p. 04-08; GOULART, Sandra Lucia et al. Op. cit., p. 30; CARNEIRO, Henrique. Op. cit., p. 65. 
que compõem a ciência conjunta do direito penal $^{7}$. Para lidar com a política criminal de drogas, portanto, não podem os juristas prescindir de estudos das ciências humanas e sociais, algo de que as faculdades de direito do país permanecem bastante carecedoras $^{8}$. E o presente trabalho, realizado no âmbito de uma faculdade de direito, tenciona oferecer sua pequena contribuição nesse mister, no que toca a aspectos histórico-sociológicos e suas relações com a disciplina jurídico-penal ${ }^{9}$.

O consumo de drogas, quando inadequado, constitui um mal a ser controlado, mas que, arriscamo-nos a dizer, jamais será extinto. É preciso que se consiga lidar adequadamente com a questão, e não parece ser o direito penal o melhor meio de se tutelá-la juridicamente. É o que levam a crer os resultados históricos do proibicionismo penal aplicado ao longo do século XX, seja do ponto de vista de sua (in-)eficácia preventiva, seja do ponto de vista das conseqüências sociais nefastas dele exsurgidas, ou, ainda, considerando-se a própria carência de legitimidade da utilização do direito penal para o tratamento da questão.

Parece-nos, de fato, que precisamente o estudo histórico das relações entre seres humanos e drogas pode fornecer valiosos subsídios para se trabalhar com o tema, na medida em que não apenas desvela as curiosas raízes do atual proibicionismo, como, acerca particularmente do consumo, permite "abandonar o terreno das puras suposições, e estabelecer critérios sobre fatos verificáveis" $"$. Assim, resguardadas as alterações sócio-culturais entre diferentes tempos e sociedades, "não apenas mostra [...] o que acontece com o consumo de tal ou qual droga quando é ilegalizada, mas o que ocorre ao deixar de ser ilegal uma dentre as antes proibidas, como aconteceu com o ópio na China e o álcool nos Estados Unidos" $"$. Por essa razão, concede-se especial relevo a um estudo histórico do tema no presente trabalho.

\footnotetext{
${ }^{7}$ Sobre a evolução da noção de ciência conjunta do direito penal, vide: DIAS, Jorge de Figueiredo. Direito penal - parte geral, t. I. São Paulo - Coimbra: Revista dos Tribunais - Coimbra Editora, 2007, p. $18-41$.

${ }^{8}$ Cabe ressaltar, entretanto, que foge ao escopo do presente trabalho cobrir detidamente cada um dos citados aspectos, cuja referência se deve ao intento de ressaltar a necessidade de diálogo com as demais áreas do conhecimento afetas ao tema.

${ }^{9}$ Destarte, houve que se afastar do escopo do trabalho considerações teóricas sobre a legislação positiva de drogas, porquanto se analisa a criminalização em si e sua legitimação.

${ }^{10}$ ESCOHOTADO, Antonio. Historia general de las drogas, $3^{\mathrm{a}}$ ed. Madrid: Espasa, 2000, p. 28.

${ }^{11}$ Idem, ibidem, p. 28.
} 
De outra parte, importa atentar-se para o fato de que o mercado ilegal das substâncias psicoativas ilícitas produz, a cada ano, uma receita estimada pela ONU em cerca de US\$ 400 bilhões, equivalentes aproximadamente a $8 \%$ de todo o comércio internacional realizado no planeta $^{12}$. Nessa medida, pode-se considerar o proibicionismo um verdadeiro serviço prestado à criminalidade que, devido às políticas oficiais, detém a quase exclusividade da distribuição de um produto largamente desejado no mercado, e de altíssimo valor de troca. Este, artificialmente elevado pelas mesmas políticas ${ }^{13}$, que parecem ignorar a baixíssima elasticidade da demanda nesse peculiar mercado. Revela-se admirável, nesse mister, a facilidade com que os órgãos oficiais estadunidenses, notadamente o Drug Enforcement Administration (DEA) "tem persuadido os países europeus a adotar as suas táticas falhas, e imposto-as ao terceiro mundo"14.

Inúmeros são os resultados adversos obtidos pela doutrina da proibição ao longo do século XX, dos quais convém citar alguns:

- $\quad$ O relatório World Drug Report 2007, do Escritório das Nações Unidas sobre Drogas e Crime (UNODC), revelou que aproximadamente 200 milhões de pessoas $(4,8 \%$ da população mundial entre 15 e 64 anos) consumiram drogas pelo menos uma vez no ano de 2006, e aproximadamente 110 milhões de pessoas ( $2,6 \%$ do mesmo contingente) o fizeram ao menos uma vez em cada mês do ano ${ }^{15}$;

- Desses cerca de 200 milhões, aproximados 160 milhões de pessoas consumiram maconha, 25 milhões tomaram anfetaminas, 16

\footnotetext{
12 DAVENPORT-HINES, Richard. The pursuit of oblivion: a global history of narcotics. London New York: W. W. Norton, 2002, p. 11.

${ }^{13}$ Idem, ibidem, p. 14.

${ }^{14}$ Idem, ibidem, p. 15 (grifos nossos). Trad. livre.

${ }^{15}$ Disponível em: <https://www.unodc.org/unodc/en/data-and-analysis/WDR-2007.html>. Acesso em: 10/10/2008. Anote-se, contudo, que, segundo a mesma fonte, o número de pessoas que abusaram de alguma(s) das aludidas substâncias se mostra bastante inferior ao da generalidade de seus consumidores: 25 milhões, ou $0,6 \%$ daqueles entre 15 e 64 anos.
} 
milhões fizeram uso de opiáceos em geral, 14 milhões consumiram cocaína e 11 milhões, heroína ${ }^{16}$;

- A despeito de se gastarem fortunas no combate ao fornecimento de drogas ilícitas, e de se comemorarem reduções nas áreas cultivadas em países como Colômbia, Bolívia e Peru, a relativa redução nos preços das substâncias em seus destinos finais sugere que o incremento da produtividade superou as perdas, ampliando-se, destarte, a oferta ${ }^{17}$;

- Malgrado as proibições legais, estima-se que em nada menos que 172 países e territórios do globo ocorra o regular cultivo doméstico da cannabis $^{18}$, o qual também se supõe haver-se expandido como resultado das investidas oficiais sobre $\mathrm{o}$ fornecimento da droga;

- Os Estados Unidos, país que constitui o grande modelo e incentivador da proibição, despendem, atualmente, mais de US\$ 9 bilhões anuais somente para manter encarcerados violadores de normas penais relativas a drogas ${ }^{19}$;

- Apesar de o gasto norte-americano com a guerra às drogas ter se elevado de US\$ 1,65 bilhões em 1982 - quando se retomaria, pelas mãos da administração Reagan, o discurso e a práxis belicistas consagrados pelo ex-presidente Nixon - para US\$17,7 bilhões em 1999, neste ano, mais da metade dos adolescentes estadunidenses haviam experimentado ao menos um tipo de droga ilícita antes de completar o ensino médio ${ }^{20}$;

\footnotetext{
${ }^{16}$ Ibidem. Acesso em 10/01/2008.

${ }^{17}$ Ibidem. Acesso em 10/01/2008.

${ }^{18}$ Ibidem. Acesso em 10/01/2008.

${ }^{19}$ DAVENPORT-HINES, Richard. Op. cit, p. 16.

${ }^{20}$ Idem, ibidem, p. 16.
} 
- O Reino Unido possui um dos mais severos regimes de restrição ao uso em seu continente; contudo, seus índices de consumo estão entre os mais altos ali $^{21}$;

- O continente europeu apresenta algumas variações nas legislações internas aos Estados que sugerem haver pouca associação entre a prevalência do uso ilícito de drogas e o grau de repressividade de sua política; os países em geral apresentam níveis moderados de consumo, independentemente da ilicitude ou não das substâncias $^{22}$.

Destarte, resta notória a parca eficácia preventiva do tratamento penal destinado à matéria - o qual, por outro lado, forja artificialmente um mercado paralelo de proporções gigantescas, flagrantemente criminógeno, que adiante será estudado com maior detalhamento. Isso porque, após toda uma centúria de império do proibicionismo legal, já se constatou que "não é a droga em si que leva um dependente ao crime, mas a necessidade da droga. Não é o fornecimento da droga que torna o usuário um criminoso, mas a ilicitude de seu fornecimento"23, constatação igualmente a ser desenvolvida nas páginas a seguir.

Nada obstante, não se pode deixar de fazer alguma referência, aqui, a uma questão aparentemente óbvia, porém muito menos suscitada do que, em tese, deveria sê-lo: o que faz com que existam drogas lícitas e drogas ilícitas? Não há, efetivamente, um critério objetivo que as distinga, além da mera previsão legal reitere-se, deveras arbitrária como critério diferenciador. $\mathrm{O}$ questionamento se torna ainda mais digno de admiração uma vez que se sabe serem o álcool e o tabaco extremamente prejudiciais à saúde humana, e potencialmente mais danosos, sob diversos aspectos, do que a quase generalidade das substâncias psicoativas ilícitas ${ }^{24}$.

${ }^{21}$ Idem, ibidem, p. 17.

${ }^{22}$ Idem, ibidem, p. 17.

${ }^{23}$ Idem, ibidem, p. 17. Trad. livre.

${ }^{24}$ Estudo publicado em 2004 pela OMS aponta serem o álcool e o tabaco causadores de um número de mortes, no mundo todo, superior em trinta vezes ao número causado pelo conjunto de todas as substâncias ilícitas. Aponta ainda serem o álcool e o tabaco dez vezes mais nocivos à saúde humana do que a média das drogas ilícitas. Neurociência do uso e dependência de substâncias psicoativas. 
Como se supõe, há uma forte questão cultural a responder parcialmente a indagação, mormente no que se refere ao álcool, na medida em que a aceitação social de seu consumo é bastante antiga, e perene. No entanto, assim como ele se vê inserido há muitos séculos na cultura das sociedades européias, outras substâncias também datam sua inserção cultural em tempos remotos, em diferentes regiões do globo - de que são exemplos os casos da coca na região andina e do ópio em partes do sul da Ásia. Então, parece que a explicação talvez possa residir no fato de que os países Europeus, uma vez tendo sido as metrópoles que lideraram a expansão colonial, permitiram-se exportar a sua cultura - e, indicie-se desde logo, prevalência econômica - também neste aspecto, ao passo que à periferia do capitalismo coube se submeter a ela. Ora, sabe-se tratar-se de algo também visível nos dias correntes, em que, enquanto testemunhamos a incessante repressão a camponeses andinos cultivadores de folhas de coca, remanesce inimaginável a possibilidade de que as grandes corporações industriais produtoras de tabaco e de bebidas alcoólicas, assim como os Estados nacionais que representam seus interesses, anuam a que tais substâncias sejam lançadas à ilicitude absoluta ${ }^{25}$. Eis apenas uma das solenes hipocrisias que são notadas ao se realizar um exame mais profundo do assunto, e mais um motivo pelo qual se nos afigura que o melhor caminho para lidar com o tema seria o de uma cautelosa regulamentação, devidamente orientada, retirando-se-lhe o contraproducente tratamento penal ora vigente.

O presente trabalho, naturalmente, aborda a matéria sobretudo desde o ponto de vista jurídico, e, mais especificamente, jurídico-penal, mas levando em conta, ao mesmo tempo, as tantas questões extrajurídicas cuja consideração se faz necessária para a adequada compreensão do tema. Assim sendo, cabe-nos, aqui, abordar aspectos históricos, criminológicos, sociológicos e da teoria econômica

Disponível em: 〈http://www.who.int/substance_abuse/publications/en/Neuroscience_P.pdf >. Acesso em: 10/10/2008.

${ }^{25}$ Não nos parece, cumpre esclarecer-se, que os recentes movimentos de criação de restrições legais para o consumo de tabaco em locais públicos ou mesmo privados de acesso relativamente público, verificados em diversos países da Europa, confronte-se com o quanto aqui apontado; a princípio, tratase apenas de uma necessária resposta a pressões legítimas da sociedade organizada contra o excessivo consumo de tabaco por parte da população, a fim de se prevenir parte dos problemas de saúde pública por ele gerados. Ou seja, uma busca de se regulamentar, através do controle administrativo, o consumo da referida substância. 
pertinentes. Com isso, espera-se contribuir para o melhor esclarecimento do leitor quanto a tão interessante, polêmico e relevante assunto. 


\section{REFLEXÕES INICIAIS}

Drogas podem ser prejudiciais à saúde humana - mais precisamente daqueles específicos seres humanos que as $\operatorname{consomem}^{26}-$, especialmente se administradas de modo descuidado. Podem, por outro lado, não fazer mal algum a seus consumidores, ou mesmo fazer-lhes bem ${ }^{27}$ : valore-se positivamente ou não o seu poder distrativo, há que se assinalar que o uso medicinal de substâncias como a maconha e a morfina se mantém em nossos dias, ainda que restrito e raramente autorizado $^{28}$, e que pesquisas científicas voltadas à investigação de possíveis propriedades terapêuticas em diferentes psicoativos provavelmente jamais deixaram de ocorrer em tempos modernos, e, decerto, nem sempre autorizadamente.

Cumpre afirmar, então, que o grande mal à saúde humana que pode ser causado pela existência de tais substâncias reside em seu consumo excessivo. Trata-se, aqui, de algo inegável: o consumo excessivo de droga(s) tende inexoravelmente a acarretar prejuízos à saúde física e/ou psíquica de quem a(s) tenha consumido; pode, outrossim, causar indesejada dependência física ou psíquica em seu usuário. Destarte, adotamos tal constatação como premissa primeira deste trabalho, na medida em que o consumo excessivo - ou abuso - de psicoativos, também por esse motivo ${ }^{29}$, há muito se tornou fator de especial preocupação institucional e social.

Todavia, nem mesmo a citada premissa fundamental se basta para explicar tamanha movimentação havida em torno do tema especialmente no último século e meio, e muito menos o alarmismo que tem caracterizado os debates públicos respeitantes durante todo esse tempo. Ora, é igualmente inegável que o consumo

\footnotetext{
${ }^{26}$ Embora possa parecer desnecessário excesso de rigor, ou mesmo tautologia, a explicação se presta a afastar, desde logo, a idéia de que as substâncias psicoativas sejam um mal em si, quando em verdade o problema não reside em sua existência mesma ou ainda em seu simples consumo, mas em seu eventual consumo abusivo. No mesmo sentido, vale indiciar, ora, que o consumo de drogas não parece constituir algo nocivo à saúde pública, mas sim à saúde individual - e, não obstante, essa nocividade se dá apenas ocasionalmente.

27 Para os fins deste trabalho, desconsidera-se o fato de medicamentos em geral também serem referidos, nas mais diversas línguas, como "drogas", o que facilitaria o esclarecimento que se faz neste momento; o vocábulo drogas, aqui, designará exclusivamente substâncias psicoativas cujo uso ordinário atual não compreende terapias médicas ortodoxas.

${ }^{28} \mathrm{E}$, por vezes, às escondidas das instituições médicas e estatais.

${ }^{29}$ Outras das muitas razões que determinaram o crescente protagonismo oficial no controle da relação entre indivíduos e substâncias tóxicas através da elaboração de políticas disciplinadoras de seu consumo e comércio haverão de ser estudadas em capítulo próprio.
} 
excessivo de qualquer substância, seja ela um remédio, alimento, bebida, etc., tende a ser nocivo à saúde humana individual, em maior ou menor medida de acordo com suas propriedades específicas ${ }^{30}$ e com níveis subjetivos de tolerância. A seu turno, a dependência, seja ela física ou psíquica, é algo que requer seja tratado sob o ponto de vista médico, assim como ocorre com inúmeras outras enfermidades, e apresenta incidência relativamente pequena - tanto em relação ao número de consumidores de drogas quanto em relação à incidência global e à letalidade de outras patologias que, no entanto, provocam menor comoção social ${ }^{31}$. Isso parece significar que a mera nocividade potencial à saúde humana contida em substâncias psicoativas deva ser insuficiente para justificar tamanhas preocupações, ainda que se lhes pressuponha, grosseiramente, eventual nocividade superior à da generalidade dos alimentos e bebidas (não-alcoólicas).

De toda sorte, porém, ao contrário do que costuma ocorrer no caso de alimentos e bebidas, muita vez o consumo de determinadas drogas pode constituir situação incômoda a eventuais indivíduos que se vejam geograficamente próximos de quem as esteja consumindo. Isso se dá particularmente no caso de substâncias consumidas por meio fumívomo, visto que espalham no ar resíduos decorrentes de sua combustão e da expiração do fumante, os quais, além de poderem apresentar alguma (limitada) nocividade à saúde de terceiros, podem igualmente apresentar odores desagradáveis. É de se ver, todavia, que esse fator tampouco é apto - se é que em algum momento, mesmo que como parte de um conjunto de fatores, chegou a ser considerado para tanto - a justificar a situação de verdadeira emergência social que persegue o tema do consumo de psicoativos em geral. E, se o fosse, tornaria ainda mais contraditória a licitude e a aceitação social do tabaco, por óbvias razões.

\footnotetext{
${ }^{30}$ Ademais da remissão a substâncias de ingestão ordinária, e tratando igualmente das variações de efeitos - positivos e negativos - que uma mesma substância, qualquer que seja ela, pode conter, anota Neuman: "os cientistas, desportistas e pescadores sub-aquáticos sabem que o oxigênio altamente concentrado em seus tanques produz alucinações e euforia com conseqüências que podem ser fatais. $\mathrm{O}$ mesmo caberia dizer da aplicação no cérebro de eletrodos que levam da calma absoluta ao pânico. Existe também a 'drogadição sem droga' de quem se estupidifica em frente ao televisor durante horas ou faz da comida uma panacéia adictiva". NEUMAN, Elías. La Legalización de las drogas, $3^{\mathrm{a}}$ ed. reestruct. e ampl. Buenos Aires: Editorial Universidad, 2005, p. 25. Trad. livre.

${ }^{31}$ Estima-se que a diabetes, por exemplo, mate cerca de 3 milhões de pessoas anualmente em todo o mundo, número mais ou menos equivalente à quantidade total de dependentes de drogas - ou seja, todos aqueles que tecnicamente sofrem problemas de saúde decorrentes do consumo de psicoativos atualmente existente. A respeito, vide: <http://www.who.int/diabetes/facts/en/index.html $>$. Acesso em: 10/01/2008.
} 
Tampouco a própria psicoatividade inerente às drogas parece ser bastante para que mereçam o tratamento que lhes vem sido dispensado: cafeína, açúcar, álcool, tabaco e medicamentos manufaturados com propriedades psicoativas transitam livremente nos mais variados círculos sociais desde há muito, e seu consumo é estimulado pelas mais diferentes fontes e de diversas maneiras - e, muitas vezes, confere elevado status social ao consumidor.

Ainda não é o momento, aqui, de se referir aos significativos - e inquestionáveis - males sociais desordenadamente apresentados como conseqüências diretas do consumo de psicoativos, o qual implicaria toda uma cadeia criminosa a partir da disponibilização dessas substâncias à venda. Por ora, pretende-se apenas lograr uma breve e isolada reflexão quanto à estigmatização social do mero uso de entorpecentes.

Deveras, mesmo que fosse possível pressupor, de algum modo, uma perniciosidade ontológica e insuperável sobre o consumo - qualquer consumo - de tais substâncias, ainda assim seria de se questionar tamanho alarmismo acerca de algo que, pelo menos enquanto não implica ofensa real a terceiros, realmente parece dizer respeito à esfera privada da vida de cada cidadão responsável.

E, no entanto, constata-se que a prática de se consumir drogas constitui algo verdadeiramente demonizado em nossa sociedade - não parece haver adjetivação mais apropriada que esta se se pretende significar algo como espécie de materialização do mal. Demonizado é o consumo de drogas, e igualmente demonizados são a própria droga e seu consumidor, bem como o seu negociador. Tal é o que se depreende da observação quotidiana do noticiário de jornais, revistas, televisão ou de singelas conversas entre pessoas que freqüentem o mesmo ambiente social - onde se reproduzem e multiplicam as informações oferecidas pela comunicação social $^{32}$. Contudo, embora devesse ser fácil explicar toda essa

\footnotetext{
${ }^{32}$ Compreenda-se amplamente, aqui, a expressão "comunicação social”, visto que a referência cabe a cada um de seus quatro desígnios, e põe-se deliberadamente com este propósito (c. social: "1 aquela que se processa entre uma fonte organizada de informação - empresa, organização governamental ou não governamental, etc., ger. por intermédio de equipes especializadas - e a comunidade 2 p. met. [por metonímia] atividade profissional que se ocupa de tal função 3 m. q. comunicação de massa ['forma de comunicação dirigida a um número de pessoas numericamente vasto, disperso, heterogêneo e anônimo, e que utiliza, para atingir sua audiência, aparelhos e dispositivos de edição, reprodução, transmissão, distribuição e comercialização das mensagens] 4 m. q. comunicação humana ['a que se
} 
preocupação revestida de aparente consenso social, uma reflexão preliminar a respeito, como a presente, ao tencionar isolar as drogas e seu consumo de circunstâncias que lhes sejam externas, não logra explicá-la de maneira minimamente satisfatória. Afigura-se haver, mesmo, um importante fator ideológico a determinar tamanha intolerância à mera existência e ao consumo de tais substâncias - e às pessoas a elas ligadas de algum modo; todavia, por seu maior distanciamento da disciplina jurídica, um aprofundamento nesse particular também não será escopo deste trabalho.

Lembre-se que o uso de psicoativos conviveu harmonicamente com a organização social e política das mais diferentes sociedades ao longo de milênios, tendo se tornado motivo de mais aguda preocupação apenas a partir do século XIX. Cabe indagar-se, então, o que teria ocasionado tal mudança, e de que modo a situação presente harmoniza-se com os critérios jurídico-penais e constitucionais do nosso tempo.

\subsection{Aproximação do problema}

Existe, porém, nesta primeira década do século XXI, e já desde muito, um outro grande problema comum a diferentes sociedades humanas e Estados nacionais: há uma guerra em curso, que reclama incessantemente o dispêndio de enormes quantias dos orçamentos públicos e privados. Essa guerra, que repetidamente anuncia a morte ou a decadência física e psíquica de milhões de pessoas e que produz inestimáveis conflitos sociais e familiares ao mesmo tempo em que tenciona contê-los, parece estar muito longe de terminar - se é que, nalgum dia, conhecerá um fim. Há que se indagar se esta guerra apresenta-se idônea para tratar do problema do uso e comércio de psicoativos tal como se propõe, ou se, em vez disso, constitui em si mesma um grande problema; seja porque ineficaz, seja porque ilegítima. De todo modo, ao menos por ora, cumpre afirmar a necessidade de se examinar o problema do tratamento jurídico dispensado às condutas associadas ao 
uso e comércio de drogas, para o que, necessariamente, observar-se-ão criticamente problemas de natureza jurídica e social ocasionados pela citada guerra.

A quantidade de usuários de drogas distribuídos pelo mundo realmente impressiona: cerca de 200 milhões de pessoas, quase $5 \%$ da população mundial adulta, consomem psicoativos ilícitos todos os anos. Se se incluírem nesse cálculo usuários de tabaco e álcool, a estimativa passa a apontar mais de 3 bilhões de pessoas, algo próximo a nada menos que $65 \%$ da população mundial entre 15 e 64 anos, e a $50 \%$ de toda a população global.

Cingindo-se às substâncias mantidas na ilicitude, os poucos números ora apresentados são suficientes para atribuir-lhes status de bens deveras relevantes, na medida em que algo desejado por um em cada vinte seres humanos adultos - e cujo desejo é satisfeito, inclusive, a despeito de sua expressa e quase irrestrita proibição - merece que se lhe confira correspondente importância social. Entretanto, a circunstância de tratar-se de bens de consumo relevantes se traduz em situaçãoproblema a partir do momento em que se deixa de analisar, isoladamente, o consumo em si, e passa-se a observar a realidade que o circunda - desde a dependência e a marginalização social do usuário até a distribuição ilegal das drogas, o seu combate e a exclusão social de qualquer pequeno trabalhador desse mercado marginal, incluindo-se ademais toda uma série de problemas sociais colaterais. Importa esclarecer, contudo, que o fato mesmo de uma significativa parcela da população mundial consumir algo que pode ou não fazer-lhe mal à saúde talvez não configurasse, em princípio, um problema não fosse o fato - indubitavelmente extrínseco às substâncias e ao seu consumo - de esse algo ser considerado ilícito, o que converte quase toda essa relevante parcela da população do planeta em infratores legais; no mais das vezes, como é notório, criminosos.

Posto o problema, não há dúvidas de que a humanidade precisa procurar constantemente as melhores maneiras de se lidar com ele no âmbito do Estado Democrático e Social de Direito, naturalmente dentro de possibilidades factíveis e respeitando-se idiossincrasias regionais de ordem cultural, econômica e social. Nos dias correntes, bem se sabe, impera a política do chamado proibicionismo legal, o qual recorre de modo generalizado à utilização do mais poderoso 
instrumento estatal de constrição da liberdade individual: o direito penal, com todas as suas implicações sociais perniciosas ${ }^{33}$, que no caso das políticas públicas sobre drogas parece desempenhar um papel resolutamente oposto àquele a que se propõe ou deveria propor-se ${ }^{34}$. Por uma série de razões a serem desenvolvidas durante todo este trabalho, o dito proibicionismo nos parece equivocado.

\subsection{Sobre as drogas legais universais - o álcool e o tabaco}

Antes de cuidar da relação estabelecida entre o uso e distribuição de substâncias psicoativas e o tratamento penal a tais condutas destinado, e antes mesmo de abordar os processos históricos que culminaram na hegemonia do proibicionismo, cabe tratar de algo aparentemente contraditório com a proibição quase total de quaisquer comportamentos associados (ou associáveis) à interação entre seres humanos e drogas: a peculiar licitude de duas drogas particularmente relevantes e deletérias - o álcool e o tabaco.

Com efeito, em um mundo cujas instituições expressam tanta preocupação com a tutela da saúde pública quando se trata do uso de substâncias psicoativas, cabe indagar quais haveriam sido os critérios lógicos ou farmacológicos justificadores de sua plena - e consagrada - licitude.

\subsection{1. Álcool}

A Organização Mundial de Saúde estima que, em todo o mundo, cerca de 2 bilhões de pessoas consumam bebidas alcoólicas com alguma regularidade, e que, dessas, aproximadamente 80 milhões padeçam de alguma sorte de alcoolismo ${ }^{35}$.

\footnotetext{
33 Já tivemos oportunidade de nos manifestar brevemente, de modo genérico, acerca da atuação do direito penal como instrumento de controle social formal e de suas conseqüências sociais negativas, ressalvando tratar-se de instrumento jurídico-político necessário à coexistência humana: "Breve estudo acerca da atuação das instâncias de controle social formal e informal." In: Ultima ratio, ano 1, n. 1. Rio de Janeiro: Lumen Juris, 2007, esp. pp. 498-501.

${ }^{34}$ SICA, Leonardo. "Funções manifestas e latentes da política de war on drugs". In: REALE JR., Miguel. Drogas: aspectos penais e criminológicos. Rio de Janeiro: Forense, 2005, pp. 15-16.

35 WORLD HEALTH ORGANIZATION. WHO Global status report on alcohol 2004. Geneva: World Health Organization, 2004, p. 01. Disponível em:
} 
Estima, ainda, que algo entre $20 \%$ e $30 \%$ das incidências globais de câncer no esôfago, câncer no fígado, cirrose hepática, convulsões epilépticas, acidentes de trânsito e homicídios estejam relacionados com altos níveis de consumo de bebidas alcoólicas $^{36}$. Anualmente, cerca de 1,8 milhões de pessoas morrem em virtude de problemas decorrentes do consumo de álcool, número correspondente a 3,2\% do total de mortes em todo o planeta ${ }^{37}$.

Com efeito, o álcool é uma substância quase onipresente, visto que se mantém ao alcance de qualquer pessoa adulta na maioria dos países. Afora a existência de algumas limitadas restrições para a sua comercialização, apresenta plena aceitação social e, em muitos casos, seu consumo é visto como indicador de status social diferenciado. Não por acaso, publicações especializadas em bebidas alcoólicas são vendidas a altos preços em estabelecimentos igualmente especializados, os quais freqüentemente promovem rituais de degustação de bebidas. Como se diz, a regular ingestão de bebidas alcoólicas faz parte de nossa cultura, conquanto se trate de uma droga que mata e debilita mais pessoas do que a somatória de todas as outras drogas conhecidas ${ }^{38}$, à exceção do tabaco.

Profissionais de saúde pública em geral tendem a reconhecer que o consumo de álcool afeta praticamente todos os órgãos do corpo humano, tendo relações etiológicas identificadas com mais de sessenta enfermidades ${ }^{39}$. Há, pelo menos, nove diferentes patologias exclusivamente causadas pelo consumo de álcool $^{40}$, o qual incrementa possibilidades de ocorrência de graves males como os cânceres de boca, faringe, laringe, hipofaringe (laringofaringe), esôfago e fígado ${ }^{41}$,

〈http://www.who.int/substance_abuse/publications/global_status_report_2004_overview.pdf〉. Acesso em: 10/10/2008.

${ }^{36}$ Idem, ibidem, p. 01. Acesso em: 10/10/2008.

${ }^{37}$ Idem, ibidem, p. 01. Acesso em: 10/10/2008.

${ }^{38}$ NEUMAN, Elías. La Legalización de las drogas, $3^{\mathrm{a}}$ ed. reestruct. y ampl. Buenos Aires: Editorial Universidad, 2005, p. 21.

${ }^{39}$ WORLD HEALTH ORGANIZATION. Op. cit., p. 35. Acesso em: 10/10/2008.

${ }^{40}$ Nomeadamente: psicose alcoólica, síndrome de álcool-dependência, abuso alcoólico, polineuropatia alcoólica, cardiomiopatia alcoólica, gastrite alcoólica, cirrose hepática alcoólica, excesso de álcool na corrente sangüínea, toxomania de etanol e metanol. In: WORLD HEALTH ORGANIZATION. Ibidem, p. 37. Acesso em: 10/10/2008.

${ }^{41}$ Idem, ibidem, p. 37. Acesso em: 10/01/2008. Estudos recentes sobre a eventual influência do consumo de álcool sobre a ocorrência de outras modalidades de câncer (v.g., estômago, pâncreas, ovários, próstata, reto e glândulas salivares) têm se revelado inconclusivos; ainda, afigura-se que o álcool pode ser também um significativo adicionador de risco à incidência de câncer de mama. Idem, ibidem, pp. 37-38. Acesso em: 10/10/2008. 
hipertensão, ataques hemorrágicos, pancreatite, epilepsia, psoríase, depressão e diversos males congênitos derivados de ingestão pré-natal ${ }^{42}$.

Além dos danos físicos e mentais que pode causar a seus usuários, não se questiona, igualmente, a sua potencialidade causadora dos denominados danos sociais, ligados ao comportamento social do indivíduo, e que compreendem problemas familiares, desordem pública, redução da capacidade laboral, acidentes de trabalho e de trânsito, delitos contra a pessoa e contra a vida - culposos e dolosos -, etc. Os danos sociais decorrentes do mau uso de bebidas alcoólicas são de muito difícil quantificação estimada, mas podem, eventualmente, ser ainda mais lesivos do que as patologias supra-aludidas ${ }^{43}$, pelo que interferem no bem-estar humano e, destarte, são igualmente considerados pela OMS como matéria de interesse da saúde pública em geral $^{44}$.

Consoante já brevemente mencionado, entre os danos colaterais decorrentes do consumo de álcool encontra-se a prática de diferentes crimes: homicídios, lesões corporais, danos ao patrimônio, crimes contra a honra, crimes sexuais, entre outros ${ }^{45}$, além dos quotidianos delitos culposos resultantes de acidentes de trânsito. Acredita-se, porém, que crimes dolosos cometidos sob a influência da ingestão de álcool tendam a refletir pensamentos e fatos previamente subjacentes ao intelecto de seus autores respectivos ${ }^{46}$, que se vêem potencializados ou têm a sua prática facilitada pela perda dos freios inibitórios ensejada pelo estado de embriaguez. O mesmo se tem dito, importa observar, acerca de casos de delitos cometidos por pessoas sob influência do consumo de determinadas drogas consideradas ilícitas.

Deveras, na medida do que se pode generalizar - dadas as variações existentes entre as numerosas substâncias psicoativas conhecidas -, são muitas as semelhanças verificáveis entre drogas tratadas de maneiras tão díspares. Em primeiro

\footnotetext{
${ }^{42}$ Idem, ibidem, pp. 38-40. Acesso em 10/10/2008.

${ }^{43}$ Idem, ibidem, p. 35. Acesso em 10/10/2008.

${ }^{44}$ Idem, ibidem, p. 35. Acesso em 10/10/2008.

45 Anote-se, a propósito, que a tutela penal como circunstância agravante da embriaguez preordenada (art. 61, inc. II, $l$ do Código Penal) demonstra que a incidência massiva da prática de delitos nessa circunstância vem sendo constatada há muito em nossa realidade social.

${ }^{46}$ NEUMAN, Elías. La Legalización de las drogas, $3^{\mathrm{a}}$ ed. reestruct. y ampl. Buenos Aires: Editorial Universidad, 2005, p. 21.
} 
lugar, a etiologia que leva a qualquer situação de dependência não apresenta diferenças significativas entre uma e outras substâncias, supondo, ademais, maior transcendência de fatores sociais, familiares e ligados ao psiquismo individual ${ }^{47}$. Ademais, os mencionados danos sociais colateralmente provocados pelo consumo excessivo de tais substâncias se revelam bastante similares em ambos os casos. Não obstante, os motivos alegados para o seu consumo ${ }^{48}$ - antes, naturalmente, da eventual superveniência de crises de abstinência ou de dependência - também se assemelham, assim como os conhecidos efeitos de alteração na percepção da realidade.

Em todo caso, como visto, é certo que os numerosos e intensos danos aos indivíduos e à sociedade decorrentes da massificação do consumo de álcool são facilmente determináveis e demonstráveis. Ao revés, há casos de drogas proibidas sobre cujos danos potenciais ainda não se atingiram estudos conclusivos, sendo que o conhecimento de sua possível lesividade não ultrapassou alguma investigação empírica e discussões acadêmicas ${ }^{49}$. Portanto, e coerentemente, é de se indagar qual teria sido o critério de proteção da saúde pública ou mesmo da saúde individual que teria levado à proibição absoluta e à declaração de guerra contra substâncias que se afiguram menos lesivas.

Efetivamente, já houve, em um passado não tão distante, uma experiência de proibição do álcool. Como resposta a pressões de grupos sociais moralistas as quais já duravam algumas décadas, e legitimando-se em critérios da ciência médica $^{50}$, os Estados Unidos promulgaram, em 1918, a $18^{\mathrm{a}}$ emenda à sua carta constitucional e, um ano depois, o Volstead Act, que estabelecia a ilicitude de toda a cadeia produtiva, estocagem, distribuição, comercialização importação, exportação e consumo de bebidas alcoólicas naquele país. Os resultados do controle social total resultante da assim-chamada "lei seca" são tão conhecidos quanto

\footnotetext{
${ }^{47}$ Idem, ibidem, p. 22.

${ }^{48}$ Podem-se citar muitos - distração de problemas quotidianos, fuga de situações rotineiras, diversão, inserção em determinado contexto social, atendimento a solicitação prévia de um terceiro (este, possivelmente motivado por razões como estas), experimentação individual, etc. -, invariavelmente marcados por propósitos, a princípio, recreativos. Davenport-Hines resumiu tais motivos no título principal atribuído à sua obra: "a busca do esquecimento" (trad. livre). DAVENPORT-HINES, Richard. The Pursuit of oblivion: a global history of narcotics. London - New York: W. W. Norton, 2002.

${ }^{49}$ NEUMAN, Elías. Op. cit., p. 21.

${ }^{50}$ Idem, ibidem, p. 22.
} 
lamentados: da potencialização do negócio ilegal aproveitaram-se as máfias para experimentar inédito crescimento, sem que a hipertrofia da burocracia estatal forjada naqueles tempos constituísse óbice às atividades daquelas - que se locupletavam, igualmente, do alto poder corruptor decorrente da lucratividade extraordinária do mercado ilegal. Porque ineficaz e contraproducente, a proibição do álcool viu-se abolida em 1933, com a promulgação de $21^{\mathrm{a}}$ emenda, mas as implicações negativas de quinze anos de equívoco não seriam facilmente superadas: a vigência da proibição criou uma cultura de desobediência às prescrições legais entre muitos habitantes do país, e acentuou a estigmatização e a segregação social de grupos determinados de consumidores de bebidas. Não obstante, a vigência do Volstead Act forjou um ambiente profícuo para o surgimento, crescimento e desenvolvimento de organizações criminosas, que puderam aprimorar seus modi operandi naquele período $^{51}$.

A experiência estadunidense com o álcool constitui exemplo singular de legalização de uma substância psicoativa a que se houvera reservado a ilicitude absoluta, e parece lícito crer que a $21^{\mathrm{a}}$ emenda constitucional se revelou muito mais bem-sucedida do que ocorrera com a sua antecessora, a $18^{\mathrm{a}}$ emenda. A partir de então, em que pesem as suas conhecidas potencialidades lesivas à saúde humana e à convivência social, o álcool incorporou-se definitivamente aos interesses e valores da sociedade capitalista, bem como aos padrões morais da civilização ocidental. Ao passo que poucos gastam esforços em negar as tentações contidas no extenso rol de bebidas alcoólicas disponíveis no mercado, os motivos ou pretextos a que pessoas recorrem para consumi-las não parecem, absolutamente, suscitar qualquer comprometimento a valores morais fundamentais vigentes em nossas sociedades ${ }^{52}$.

Para se supor a importância social e econômica adquirida pelo consumo e comércio de bebidas alcoólicas, basta imaginar-se a quantidade de pessoas ocupadas com os cultivares - de vinhas, cevada, agave, trigo, centeio, arroz, aveia, milho, cana-de-açúcar, entre outros - destinados à produção de bebidas, além das que trabalham na produção dos insumos ali utilizados; os caminhoneiros

\footnotetext{
${ }^{51}$ Costuma-se apontar os anos de 1920 nos EUA como o momento e o local onde teriam se desenvolvido as atividades do crime organizado e as práticas de lavagem de dinheiro tal como as conhecemos modernamente.

${ }^{52}$ NEUMAN, Elías. Op. cit., p. 23.
} 
ocupados do transporte das colheitas; os agrônomos, os enólogos, cervejeiros e seus análogos; os fabricantes de máquinas e equipamentos necessários ao processamento industrial de bebidas; os fabricantes de garrafas, latas e garrafões, e os ocupados com o próprio envasamento; os fabricantes das etiquetas das garrafas; os exportadores, importadores, distribuidores, comerciantes, garçons; etc. Deveras, o atual estágio de complexidade das relações econômicas que envolvem a matéria somente reforça a conclusão por sua perfeita adaptação ao modus vivendi da sociedade contemporânea.

Há, ainda, o trabalho de empresas publicitárias e de comunicação social que procura induzir publicamente o consumo do álcool, vendido como um "prazer paliativo de distrações sociais manipuladas"

Cumpre anotar ${ }^{54}$, porém, que o álcool, também pode apresentar benefícios à saúde humana até um determinado grau. Estudos recentes citados pela OMS sugerem que o consumo leve ou moderado de bebidas alcoólicas tende a implicar algum efeito protetivo contra males como isquemia cerebral (embora aumente riscos de ataque hemorrágico cerebral), doenças coronárias, diabetes e colelitíase (cálculo biliar) ${ }^{55}$. Não parece, porém, que tais efeitos positivos do consumo de álcool - repise-se, apenas recentemente consolidados - tenham sido considerados, em algum momento, na opção legislativa de sua liberação, até porque o consumo moderado de muitos dos demais psicoativos também pode apresentar benefícios.

Ainda, é interessante notar que, além do fato de influências positivas e negativas decorrentes do consumo de bebidas alcoólicas variarem de uma pessoa para outra ${ }^{56}$, pelo menos nos casos das diabetes e doenças coronárias o uso de álcool

\footnotetext{
${ }^{53}$ Idem, ibidem, p. 22. Trad. livre.

${ }^{54}$ Em um trabalho em que se pretende criticar o predomínio de fatores ideológicos em determinadas opções de criminalização, não convém, a fim de se ressaltar uma incoerência como a da oposição entre o tratamento socialmente dispensado ao álcool e aquele dispensado a outras drogas, omitirem-se argumentos que possam favorecer eventual tese oposta. Sabe-se que, ao pesquisador, cabe procurar afastar-se de pré-concepções de cariz ideológico, ao menos na medida do que lhe é possível; daí a necessidade de se mencionar as propriedades potencialmente positivas de bebidas alcoólicas. Todavia, logo se verá que tampouco este argumento pode favorecer alguma pretensão de coerência no tratamento legal e social corrente acerca das substâncias psicoativas, visto que o consumo moderado de outras drogas pode igualmente ser benéfico ao ser humano.

${ }^{55}$ WORLD HEALTH ORGANIZATION. Op. cit., pp. 38, 40-41. Acesso em: 10/01/2008.

${ }^{56}$ Idem, ibidem, passim. Acesso em: 10/01/2008.
} 
pode tanto fazer bem quanto fazer mal ao ser humano, dependentemente das quantidades ingeridas e freqüência da ingestão ${ }^{57}$.

Tais variações também em muito se assemelham ao que ocorre através do consumo de diferentes drogas mantidas na ilicitude, o que permite supor-se, desde logo, que problemas de saúde individual ou mesmo de saúde pública não resultam do mero uso de substâncias psicoativas mas, e fundamentalmente, de seu uso excessivo, ou abuso $^{58}$.

\subsubsection{Tabaco}

A imagem que ocupa todo o vídeo é a de um jovem elegante e arrojado, sem dúvida um vencedor na vida. O que terá ele feito para chegar ao sucesso? Como terá conquistado essa autoconfiança, esse olhar seguro e atrevido, esse ar de quem sabe onde pisa? Estudou muito, trabalhou arduamente? Submeteu-se, por anos a fio, a um penoso processo de psicoterapia, para se conhecer melhor?

A [se] acreditar na voz suave e convincente do locutor, não foi nada disso. Esse jovem chegou direto ao sucesso por fumar o cigarro Tal. Nada mais fácil, está ao alcance de qualquer um: o homem que sabe o que quer fuma o cigarro Qual. Basta imitá-lo. ${ }^{59}$

A narrativa supracitada ilustra com precisão a maneira encontrada pelos capitalistas da indústria do fumo para incrementarem seus lucros mediante a universalização das vendas de cigarros em todo o mundo ao longo do século XX. Durante muitas décadas - coincidentes com a ascensão e domínio da televisão como principal veículo de comunicação social de massa -, os anúncios publicitários patrocinados por marcas de cigarro estiveram entre os mais vibrantes, estimulantes e, mesmo, eficazes, tendo alguns deles se tornado clássicos da propaganda. A seu turno, também o cinema desempenhou papel fundamental na glamorização do cigarro, incutindo em seu público mensagens - explícitas, indiretas ou, ainda, subliminares segundo as quais o consumo do cigarro transmitia perante terceiros uma imagem de charme, maturidade e sucesso pessoal.

${ }^{57}$ Idem, ibidem, pp. 40-43. Acesso em: 10/01/2008.

58 Entenda-se, aqui, o conteúdo semântico do vocábulo abuso apenas como uso excessivo, desmesurado. Esta observação se faz necessária a fim de não se confundir, mais adiante, o sentido aqui empregado com aquele estabelecido em meados do século XX pelas Nações Unidas - o de qualquer uso considerado ilegal -, que será objeto do capítulo próximo.

59 ARATANGY, Lidia Rosemberg. Doces venenos: conversas e desconversas sobre drogas. São Paulo: Olho d'Água, 1991, p. 47. 
Segundo estimativas da OMS, porém, o tabaco é responsável por aproximadamente 5 milhões de mortes anuais em todo o mundo, o que representa cerca de $8,8 \%$ das mortes registradas todos os anos no planeta ${ }^{60}$. Seu consumo é associado à ocorrência de distúrbios nos brônquios e de diversos tipos de câncer, notadamente o de pulmão, bem como ao considerável incremento de riscos de infarto do miocárdio, e quase sempre acarretam significativos prejuízos à circulação sangüínea, incrementando-se, assim, os riscos de males daí advindos ${ }^{61}$.

O tabaco ocupa o quarto lugar geral na lista dos fatores responsáveis pela perda de anos de vida e incapacitação física, seguido pelo álcool, merecedor do quinto lugar; somados, tabaco e álcool são responsáveis pela perda de $8,1 \%$ dos anos de vida da população global, ao passo que ao consumo das drogas ilícitas atribui-se $0,8 \%$ dessa perda ${ }^{62}$.

O hábito de se mastigar folhas de tabaco, e mesmo de seu fumo, já era corrente no Novo Mundo tempos antes da chegada dos europeus. Estes cuidaram de transmiti-lo ao seu continente de origem e, mais tarde, para terras africanas e asiáticas. Inicialmente interessados em experienciar as potencialidades das exóticas substâncias que encontravam no continente americano - como ocorreu, igualmente, com o cacau, a batata, e o açúcar - e, ademais, em buscar mercadorias cuja explotação pudesse convir ao comércio internacional de tempos mercantilistas, os colonizadores não tardaram a perceber que as possibilidades de cultivo do tabaco nas colônias se adaptava perfeitamente à lógica econômica de então. Introduziram-se, assim, os regimes de plantations ${ }^{63}$ em vastas áreas dos territórios coloniais. E as propriedades estimulantes e limitadoras de apetite imanentes ao tabaco fez com que o seu consumo fosse sido encorajado entre trabalhadores das colônias (escravos ou não), a fim de que produzissem ao máximo e consumissem o mínimo de alimentos.

\footnotetext{
${ }^{60}$ ORGANIZAÇÂO MUNDIAL DE SAÚDE. Neurociência do uso e dependência de substâncias psicoativas. Genebra: OMS, $2004 . \quad$ Disponível em: <http://www.who.int/substance_abuse/publications/en/Neuroscience_P.pdf>. Acesso em: 10/10/2008. ${ }^{61}$ ORGANIZAÇÃO MUNDIAL DE SAÚDE. Op. cit. Acesso em 10/10/2008; ARATANGY, Lidia Rosemberg. Op. cit., pp. 62-63.

${ }^{62}$ NEUMAN, Elías. La Legalización de las drogas, $3^{\mathrm{a}}$ ed. reestruct. y ampl. Buenos Aires: Editorial Universidad, 2005, p. 27.

${ }^{63}$ Forma de produção agrícola baseada na monocultura de exportação, dominante em todo o continente americano entre os séculos XVI e XIX.
} 
O mesmo ocorreu, simultaneamente e pelas mesmas razões, com a cafeína, outra droga que, como o álcool e o tabaco, passaria a fazer parte de nossa cultura.

Já no século XX, avanços tecnológicos possibilitariam a produção e distribuição em larga escala de cigarros industrializados, oferecidos a preços bastante acessíveis. Ingressava definitivamente, destarte, o tabaco na lógica da economia capitalista industrial, e a competição empresarial passava a reclamar propagandas como as referidas no início deste subcapítulo. Propagandas cujos destinatários fossem, principalmente, as populações jovens, na medida em que o vício precoce garantiria - e segue a garantir - a perenização do consumo ${ }^{64}$.

As recentes campanhas de informação contrárias ao fumo parecem alcançar um relativo êxito no esclarecimento de consumidores em determinadas regiões, tendo os índices globais de consumo de tabaco, sempre crescentes, apresentado alguma desaceleração. Todavia, importa ressaltar que, enquanto que nos países centrais as políticas de controle sobre o consumo têm se acentuado, e com resultados positivos, a indústria do tabaco tem concentrado esforços em difundir o hábito em países periféricos, cuja população é menos informada e mais suscetível a sedutoras mensagens publicitárias e a ceder irrefletidamente às tentações da sociedade de consumo em geral. O resultante crescimento dos mercados em países subdesenvolvidos tem compensado perdas decorrentes de políticas restritivas nos Estados Unidos e Europa com sobras ${ }^{65}$. Estes, porém, beneficiados pelos saldos positivos em suas balanças comerciais, não parecem demonstrar reais preocupações acerca da saúde pública global no que concerne também a esta droga.

Não obstante, a OMS estima que, em um futuro breve, poderão morrer anualmente 10 milhões de fumantes somente em virtude do câncer pulmonar ${ }^{66}$, e equivalente número de pessoas de males cardíacos e vasculares resultantes do fumo ${ }^{67}$.

\footnotetext{
${ }^{64}$ NEUMAN, Elías. Op. cit., p. 28 . O autor ainda alude ao fato de que muitas jovens sustentam o hábito de fumar cigarros como forma deliberada de evitar sensações de fome, com o que tencionam manter-se magras (ibidem, p, 28).

${ }^{65}$ Idem, ibidem, p. 27.

${ }^{66}$ Idem, ibidem, p. 27.

${ }^{67}$ BRASIL. SECRETARIA NACIONAL ANTIDROGAS (SENAD). Cartilha sobre tabaco. Brasília, 2005, p. 24.
} 


\subsubsection{Reflexões críticas}

Não há, efetivamente, qualquer base científica a permitir que se satanize ou que se santifique este ou aquele psicoativo ${ }^{68}$, ou mesmo que determine a proibição absoluta de seu uso, até pelo fato de diferentes organismos receptores diferentes consumidores - poderem reagir de modo diverso ao consumo de idêntica quantidade de uma mesma droga ${ }^{69}$.

É de se admirar, destarte, que, em face dos eloqüentes prejuízos individuais e coletivos ensejados pela amplíssima disseminação do uso de álcool e tabaco em todo o planeta $^{70}$, esta seja plenamente consentida por Estados nacionais que fomentam ou permitem toda uma militarização da repressão a outras substâncias independentemente de sua eventual lesividade. Tamanha incoerência política, por si só, permite que se acredite haver algo de errado com a excessiva tolerância oficial sobre as drogas lícitas ou com a excessiva repressão às drogas ilícitas. Talvez - ou melhor, provavelmente - sobre ambas as situações.

Diante da mencionada carência de critérios científicos razoáveis, aparenta-se verdadeiramente arbitrária a opção política em favor de umas e em detrimentos de outras drogas para serem consumidas pela população ${ }^{71}$, separando-as

${ }^{68}$ NEUMAN, Elias. Op. cit., p. 26

${ }_{70}^{69}$ Idem, ibidem, p. 26.

${ }^{70}$ No caso do Brasil, dados recentes do Centro Brasileiro de Informação sobre Drogas Psicotrópicas (CEBRID - UNIFESP) estimam que, entre a população adulta brasileira urbana, 12,3\% sejam dependentes de álcool, e 10,1\% de tabaco. CARLINI, E. A. (superv.). II Levantamento domiciliar sobre o uso de drogas psicotrópicas no Brasil. São Paulo: CEBRID - UNIFESP, 2006, p. 33; cabe citar, ademais, que estudo epidemiológico realizado no pela mesma equipe e que avaliou internações no país por dependência e psicoses derivadas do uso de drogas entre os anos de 1988 e 1999, constatou que $91 \%$ delas eram resultantes do consumo de álcool. GALDURÓZ, José Carlos F. et al. "A Epidemiologia do consumo de substâncias psicotrópicas no Brasil: o que tem sido feito?" In: REALE JR., Miguel. Drogas: aspectos penais e criminológicos. Rio de Janeiro: Forense, 2005, p. 258-259.

${ }^{71}$ Há muito não se sustenta, pois, a antiga crença reproduzida entre nós por meio da pena de Bernardino Gonzaga. Em meados do século XX, assim se manifestou o então professor da Faculdade de Direito de São Paulo: "Através das considerações expostas, bem se compreende sejam entorpecentes o ópio ou a cocaína, por exemplo. Não assim, porém, o álcool, que embora justamente condenado como um dos grandes males sociais, não possui o mesmo poder aliciador dos primeiros, bastando considerar que possibilita até mesmo um consumo habitual, sem maiores conseqüências, enquanto dificilmente passará alguém incólume, $v . g$., por algumas poucas doses de morfina. E assim também se excluem seguramente do conceito as 'pequenas toxicomanias', como as provenientes do uso de tabaco ou de produtos contendo cafeína (café, chá, mate, etc.), que igualmente se admite possam levar a certo grau de dependência psíquica e até mesmo física, em relação ao tabaco, mas 
verticalmente em dois grupos antagônicos. E o é. Isso porque, excluindo-se a potencial lesividade à saúde individual e/ou coletiva, cumpre indagarem-se quais teriam sido os critérios de ordem médica, política, econômica e social que selecionaram substâncias para serem declaradas ilícitas e permitiram a legitimação social de outras, notadamente o álcool e o tabaco. Nessa medida, remanesce a idéia de uma supostamente consagrada inserção cultural das drogas lícitas perante a civilização humana (ocidental, naturalmente). À parte a manifesta ilegitimidade da prevalência de uma concepção eurocêntrica de mundo, ocorre que mesmo a sociedade ocidental nem sempre conviveu harmonicamente com tais substâncias: a intensa repressão oficial norte-americana ao álcool nos tempos da "lei seca" foi deflagrada porque contava, cumpre mencionar-se, com o apoio de grande parte da população local. Os casos do tabaco e da cafeína - a qual, diga-se, também gera dependência, entre outros males ${ }^{72}$ - são ainda mais exemplares, na medida em que a sua introdução nos costumes da sociedade eurocêntrica se deu de maneira artificial e é relativamente recente se comparada aos antiqüíssimos hábitos de consumo moderado de folhas de coca na América andina e de derivados da papoula no sul da Ásia.

O álcool, o tabaco e o café, entretanto, adaptaram-se rapidamente, no passado, à lógica da economia mercantilista, e, mais tarde, igualmente apresentaram rápida adaptação à lógica econômica da sociedade industrial. Serviram e servem à consolidação e manutenção de monopólios estatais e poderosos oligopólios empresariais, gerando considerável acumulação de riquezas a grupos politicamente

cujos efeitos são de todo inócuos ou de nocividade perfeitamente tolerável" GONZAGA, João Bernardino. Entorpecentes: aspectos criminológicos e jurídico-penais. São Paulo: Max Limonad, 1963, pp. 39-40. Confrontando-se tal assertiva com a realidade supra-exposta, queda-se deveras ressaltante a maneira como a seletiva ideologia proibicionista suplantou a carência de informações científicas sobre as mais diversas drogas (tanto as "boas" quanto as "más") para afirmar verdadeiro axioma desprovido de qualquer lastro científico. A distinção entre drogas lícitas e ilícitas mediante um suposto critério de lesividade à saúde individual, que chegou a supor ínfimo poder sedutor ao álcool e a pretender, como visto, que o tabaco não passasse de uma "pequena toxicomania" de efeitos "de todo inócuos ou de nocividade perfeitamente tolerável", hoje chega a se revelar ingênua, mas foi no passado abraçada, inclusive, embora acrescida de uma indefinida "nocividade social", por Greco Filho em sua importante obra sobre o tema, cuja primeira edição data de 1972. GRECO FILHO, Vicente. Tóxicos: prevenção - repressão, $11^{\mathrm{a}}$ ed. São Paulo: Saraiva, 1996, p. 03.

${ }^{72}$ Como, por exemplo, síndrome de abstinência, tolerância, ansiedade, dores de cabeça, depressão e até psicoses. Contudo, trata-se provavelmente da droga mais bem inserida na vida social contemporânea, pois pouco se reconhece a sua eventual nocividade. A respeito desta, vide o estudo "Continued comsumption of caffeine can lead to tolerance", publicado no website da Faculdade de Farmácia da Universidade do Porto. Disponível em: <http://www.ff.up.pt/toxicologia/monografias/ano0405/Cafeina/p69.htm>. Acesso em: 02/11/2008. 
fortes dos países centrais. A seu turno, a produção em larga escala de maconha, cocaína e opiáceos se manteve concentrada em regiões periféricas, inexistindo, a despeito de seu poder local, a mesma concorrência de interesses políticos e comerciais apta a forçar institucionalmente uma maior aceitação no mercado internacional. É possível, portanto, que daí derivem os motivos de fundo para a constatação de que

o Estado-razão, na sua face Estado-empresa, recorta o acesso à mente, excluindo da concorrência empresarial alguns dispositivos alter-mentes em benefício de outros. O princípio teológico do "bem" não é suficiente para ocultar das coletividades humanas que o Estado elege suas "drogas" para traficar - as drogas do Estado. ${ }^{73}$

Relembre-se: a variedade de substâncias modificadoras do campo da consciência é extremamente extensa, não se podendo apontar, entre tantas drogas legais e ilegais, quais seriam as "boas" e quais seriam as "más". Isso a despeito do discurso político maniqueísta que permanece a imperar quando se discute a matéria, aqui e alhures, como se as diferenças de tratamento jurídico entre umas e outras tivesse algo de natural ou qualquer justificação plausível - o que, como se viu, definitivamente não é o caso $^{74}$. Cabe sejam analisadas, então, as circunstâncias históricas e sociais que determinaram a emergência da proibição até hoje reinante.

\footnotetext{
${ }^{73}$ MODESTO, Luiz Sergio. As Drogas do Estado. Tese de doutoramento apresentada à Faculdade de Direito da Universidade de São Paulo. São Paulo: FDUSP, 2004, p. 08-09.

74 Os inúmeros problemas ora referidos de saúde pública causados pelo tabaco e pelo álcool, se comparados com a menor incidência de equivalentes atribuíveis ao uso de drogas ilícitas, tampouco parecem prestar-se como argumento válido em defesa da criminalização destas ou, quiçá, daqueles. Deveras, não se pode olvidar que parcela considerável dos altos níveis de consumo dos primeiros se deva, possivelmente, à maneira agressiva como foram expostos durante muitas décadas pela publicidade nos mais importantes meios de comunicação de massa, inclusive, por vezes, contando com ajuda oficial. A análise histórica da emergência do proibicionismo, a ser feita no capítulo subseqüente, demonstrará que os principais fatores reais que levaram à escolha de certas drogas para serem proibidas em detrimento de outras pouco tiveram com suas propriedades farmacológicas em si, mas com a maneira como foram assimiladas pelos estratos sociais e grupos políticos dominantes algo que deslegitima indelevelmente os pretensos critérios científicos da doutrina da proibição.
} 


\section{ANÁliSE hiSTÓRICA DO CONSUMO, DA OFERTA E DE SEU TRATAMENTO LEGAL}

A desenvolução histórica das condutas associadas ao uso e comércio de substâncias psicoativas por seres humanos é bastante rica, e, conquanto possa carecer de melhores esclarecimentos aqui e ali, já foi estudada com proficiência por autores cujas obras se tornaram indispensáveis a qualquer abordagem do tema ${ }^{75}$. Descabe aqui, portanto, envidarem-se esforços de índole historiográfica - os quais, de resto, afastam-se do escopo do presente trabalho.

Todavia, inegavelmente, para se lograr uma melhor compreensão das atuais políticas pertinentes convém recorrer-se a uma breve aproximação histórica, com o que se pretende apontar o artificialismo de uma estratégia política que, a despeito de suas conseqüências nefastas, ainda tenciona ser vista como algo natural, inevitável e inquestionável.

\subsection{Antecedentes: da Antigüidade à modernidade}

É lícito supor que, ao longo de toda a história da humanidade, raras tenham sido as civilizações - se é que as houve - que não tenham apresentado experiências com o uso de alguma substância de propriedades psicoativas.

Na Antigüidade, de maneira geral, a utilização dessas substâncias não era vista como algo profano, ao contrário do que passou a ocorrer com freqüência na história mais recente ${ }^{76}$. As drogas conhecidas eram ordinariamente sacralizadas, conquanto não necessariamente divinizadas - não eram, em via de regra, diretamente associadas a uma divindade ou ente similar; eram, sim, tidas como forças da natureza

\footnotetext{
${ }^{75}$ Vide, especialmente: ESCOHOTADO, Antonio. Historia general de las drogas, $3^{\mathrm{a}}$ ed. Madrid: Espasa, 2000, passim; do mesmo autor, ora mais sucintamente: Historia elemental de las drogas. Barcelona: Anagrama, 2003, passim. Limitando-se temporalmente à abordagem do tema desde os primórdios da Era Moderna até os tempos atuais: DAVENPORT-HINES, Richard. The pursuit of oblivion: a global history of narcotics. London - New York: W. W. Norton, 2002, passim; ainda, contendo abordagem mais limitada, conforme esclarecido pelo próprio título, McALLISTER, William B. Drug diplomacy in the twentieth century. New York: Routledge, 2000, passim.

${ }^{76}$ ESCOHOTADO, Antonio. Historia general de las drogas, $3^{\mathrm{a}}$ ed. Madrid: Espasa, 2000, p. 14.
} 
detentoras de propriedades mágicas, e já se lhes creditava algum poder medicinal ${ }^{77}$. Começou-se, em determinados locais e culturas, a catalogar espécies vegetais de acordo com suas características então conhecidas ou acreditadas, e a utilizá-las para fins curativos, ainda que a cura de um mal remanescesse sendo vista muito mais como algo de natureza metafísica, e que dentre os meios para a sua consecução remanescessem sobretudo aqueles considerados sagrados: penitência, oração, peregrinação, talismãs, e mesmo a taumaturgia ${ }^{78}$.

Não conseguiu, até os dias correntes, a historiografia determinar com segurança a época em que primeiro se experimentou o que hoje é convencionalmente conhecido como droga. Sabe-se que, já por volta de 3.100 a C., na Mesopotâmia, um ideograma sumério - a primeira linguagem escrita que se conhece - aludiu à papoula como a "planta do prazer",79; outrossim, um papiro egípcio datado de 1552 a. C., destinado aos médicos de então, tratava do uso de ópio em cerca de setecentas diferentes misturas ${ }^{80}$. Comerciantes árabes introduziram o ópio na Pérsia, China, Índia, Espanha e norte da África ${ }^{81}$. Referências literárias à droga também houve na Antigüidade, de que é exemplo a própria Odisséia de Homero: em passagem do Livro IV, Helena oferece a seu marido Menelau e a Telêmaco uma mistura de vinho com outra droga - provavelmente ópio - que teria o poder de eliminar-lhes toda mágoa, lamento e ansiedade ${ }^{82}$.

Anote-se ademais que os deuses análogos Dionísio e Baco, respectivamente partes da mitologia grega e romana, não eram associados somente

\footnotetext{
${ }^{77}$ Idem, ibidem, pp. 13-14. Argumenta-se que o momento pioneiro da medicina teórica haja ocorrido logo após a primeira fase da civilização grega, em que ainda se atribuíam às doenças causas sobrenaturais - algo bem ilustrado nas duas obras fundamentais de Homero, Odisséia e Ilíada, que apontavam as patologias humanas como intervenções superiores havidas por caprichos das divindades. A medicina primitiva, então, teria resultado da paulatina superação de tal crença e da conseqüente percepção de que a origem de tais males poderia ser terrena, possibilitando-se acreditarse em profilaxias igualmente terrenas - através, por exemplo, do uso de substâncias naturais com poderes especiais. Vale lembrar que, na Antigüidade, tênues eram as linhas que distinguiam as noções de religião, magia, medicina e mesmo a sexualidade, sendo que as drogas se faziam presentes em tradições e costumes atinentes a todos eles. CARNEIRO, Henrique. Comunicação pessoal, out/2003.

${ }^{78}$ Idem, ibidem, pp. 33 et seq; 73 et seq. Lembre-se que a crença humana na cura pelo toque régio se arrastou por séculos. Deveras, conquanto se houvesse questionado tal prática desde muito, parece razoável admitir-se que tal prática, em determinados casos, tenha sido eficaz para a cura de certas enfermidades através da ab-reação, dado o efeito psicológico que provocava no súdito ungido.

${ }^{79}$ BERRIDGE, Virginia. Opium and the people. Apud: : DAVENPORT-HINES, Richard. The pursuit of oblivion: a global history of narcotics. London - New York: W. W. Norton, 2002, p. 30.

${ }^{80}$ DAVENPORT-HINES, Richard. Ibidem, p. 30.

${ }^{81}$ Idem, ibidem, p. 30.

${ }^{82}$ HOMERO. Odisséia, trad. Manuel Odorico Mendes, $2^{\mathrm{a}}$ ed. São Paulo: Edusp 1996, p. 108.
} 
ao vinho, como muita vez se supõe, mas igualmente à papoula. Em Roma havia ainda grandes festas trienais, os bacanais, que louvavam o deus do vinho e da fecundidade, o qual também era conhecido como Liber porquanto se creditava ao consumo do vinho a libertação momentânea de toda preocupação humana, alegrando-se o espírito ${ }^{83}$.

A própria Bíblia faz inúmeras remissões ao vinho, o qual até hoje faz parte dos rituais sagrados de religiões cristãs. Em conhecida passagem do Antigo Testamento, o patriarca Noé, logo após o dilúvio, planta uma vinha que depois utiliza para se embebedar ${ }^{84}$. Nas passagens que narram a vida de Jesus Cristo, pode-se verificar um processo de sacralização do vinho, cujo ápice se daria com o ritual de purificação humana por meio de seu consumo, na última ceia. Tempos mais tarde, tal bebida se tornaria o psicoativo oficial do mundo ocidental, algo que pode ser atribuído, em grande medida, à influência do catolicismo sobre o continente europeu durante a Idade Média.

Tem-se que as substâncias psicoativas mais proeminentes ao longo da história da humanidade foram o álcool e os opiáceos: como visto, podem-se encontrar registros de seu uso ligado a rituais mágicos, religiosos ou mesmo para fins terapêuticos havido desde tempos remotos. Não obstante, a própria cannabis já fora utilizada como analgésico ainda no século XVIII a. C., tendo sido empregada reiteradamente como medicina por povos antigos dos continentes africano e asiático $^{85}$.

Já na era cristã, os romanos passaram a utilizar-se do ópio para tratar males como elefantíase, edemas, epilepsia, picadas de escorpião, entre outros ${ }^{86}$. Contudo, seus efeitos deletérios também já começavam a ser conhecidos e, por vezes, instrumentalizados: opiáceos foram utilizados pelo imperador Nero para assassinar Tibério (em latim, Britanniccus, como também é conhecido) durante um

\footnotetext{
${ }^{83}$ VICTÓRIA, Luiz A. P. Dicionário ilustrado de mitologia. Rio de Janeiro: Ediouro, s/d, p. 48.

${ }^{84}$ Gênesis, cc. IX, 20-21.

${ }^{85}$ SILVA, José Geraldo da. Op. cit., p. 170.

${ }^{86}$ DAVENPORT-HINES, Richard. The pursuit of oblivion: a global history of narcotics. London New York: W. W. Norton, 2002, p. 31.
} 
jantar, consolidando assim, no ano 55, a sua ascensão ao trono que por direito pertenceria ao último ${ }^{87}$.

Nos tempos de hegemonia do catolicismo em terras européias, desde o Baixo Império Romano, impôs-se o consumo de álcool no ocidente, e começou a ser verificada uma crescente perseguição contra outros psicoativos, sobretudo opiáceos e anticolinérgicos, que muito se ligavam a mistérios e tradições do paganismo, e eram associados a bruxarias consideradas demoníacas e amaldiçoadas ${ }^{88}$. Deveras, o cristianismo se opôs decididamente ao uso de drogas com base nas idéias de busca da auto-superação pela aflição, de inaceitabilidade do hedonismo e de não serem os homens senhores de sua existência ${ }^{89}$.

Séculos mais tarde, já na baixa Idade Média, sucederia, ainda que com limitada repercussão devido à influência exercida pela igreja, uma substancial modificação na maneira de sustentação das crenças em geral. Com efeito, estas baseavam-se, até então, fundamentalmente em um “ouvir dizer", muita vez sugerido por alguém que se arrogasse alguma autoridade moral; a partir do Renascimento, todavia, anunciar-se-ia a cultura do "ver", do constatar por si mesmo, que pouco após daria origem à empiria, posteriormente consolidada por Francis Bacon e outros - os firmadores do método científico moderno.

O período do Renascimento constituiu momento de fundação da modernidade, caracterizado notadamente pela subversão aos valores predominantes na Idade Média, e revelou, por parte de seus protagonistas, considerável insubordinação a pressupostos e axiomas inseridos entre os mais caros à Igreja Católica. Assim, e por força da emergência da empiria, substâncias cuja interdição reinara por séculos retornaram a ser objeto de análise. Passou-se a buscar, a partir de

${ }^{87}$ Idem, ibidem, p. 31.

${ }^{88}$ ESCOHOTADO, Antonio. Historia general de las drogas, $3^{\mathrm{a}}$ ed. Madrid: Espasa, 2000, pp. 220228; 236-250; 307-308. Conforme anota o autor, a perseguição religiosa a drogas e seus consumidores havida naqueles tempos era acompanhada pela repressão a uma diversidade de condutas inócuas como a manutenção de vida sexual heterodoxa, misticismo heterodoxo, igrejas reformadas, judaísmo, minorias étnicas e sociais, blasfêmia, etc. - própria de um conjunto de normas intolerante e arbitrário.

${ }^{89}$ Idem, ibidem, p. 363. Anote-se, outrossim, que Escohotado refere-se à perseguição sofrida pelas drogas no apogeu do poder clerical durante a Idade Média apontando a incompatibilidade entre o culto cristão ortodoxo e o consumo de tais substâncias e os rituais por este implicados. E, nesse mister, lembra que $o$ fato de a historiografia moderna pouco descrever a perseguição empreendida pelo cristianismo contra a cultura farmacológica então existente se deve precisamente à circunstância de que tal perseguição se fundou em métodos como queimas de livros e no sigilo imposto pelos censores oficiais. Ibidem, p. 228. 
então, estudos mais cuidadosos das plantas e seus efeitos, e, ademais, com o passar do tempo começou-se a avaliar experimentalmente, também, as plantas originárias do Novo Mundo.

Em meados do século XVI, o número de receitas médicas contendo o principal eutanásico e analgésico dos tempos antigos, o ópio, apresentava crescimento notável, assim como se ampliava o rol de males a que sua prescrição visava tratar. O mais importante cientista da época, o germânico Philipus Aureolus T. B. von Hohenheim, profissionalmente conhecido pelo prosônimo latino Paracelsus, cunhou o nome laudanum para um remédio por ele formulado e que indicava aos mais diversos males: uma mistura de diversas substâncias exóticas e cerca de $25 \%$ de ópio ${ }^{90}$. Paralelamente, observações relevantes sobre psicoativos ocorriam não apenas no Ocidente mas também no Oriente, à medida que importantes naturalistas como os ibéricos Cristóval da Costa e Garcia da Horta passavam a se ocupar da botânica tropical.

Pesquisas fundadas na doutrina do empirismo fizeram do século XVI o momento de um verdadeiro renascimento farmacológico na Europa. Mais tarde, porém, avanços nessa seara sofreriam uma retração no período marcado pelo apogeu da força dos Estados absolutistas e da inquisição e sua caça às bruxas, porquanto se continuava a pretender fortemente, e com apoio oficial, combater-se a medicina popular e os métodos de alteração da consciência.

\subsection{O capitalismo e as drogas}

A busca por drogas foi um dos grandes motores da formação do capitalismo, ao tempo da acumulação primitiva de capital e das grandes navegações. De fato, se não esperavam os conquistadores que os tesouros do continente americano fossem basicamente botânicos, é certo, porém, que se adaptaram rapidamente a essa realidade ${ }^{91}$. Entre os principais produtos que constituíram objeto fundamental da explotação colonial e do comércio e tráfico internacional figuraram:

${ }^{90}$ DAVENPORT-HINES, Richard. The pursuit of oblivion: a global history of narcotics. London New York: W. W. Norton, 2002, pp. 31-32.

${ }^{91}$ ESCOHOTADO, Antonio. Historia general de las drogas, $3^{\mathrm{a}}$ ed. Madrid: Espasa, 2000, p. 344. 
especiarias diversas e açúcar, no século XVI; álcool e tabaco, no século XVII; chocolate, chá e café, no século XVIII; e o próprio ópio, já no século XIX. Com o advento do mercantilismo, tornaram-se, pois, as drogas peças-chave da expansão da economia mercantil ${ }^{92}$, assim como as hegemonias políticas que se sucederam no cenário internacional desde o início das grandes navegações - as hegemonias ibérica, holandesa, britânica e norte-americana - deixaram flagrantes reflexos na economia das drogas e nas políticas a elas relacionadas.

Durante a época de predomínio luso-espanhol, muitos se utilizou, além naturalmente do álcool, daquelas drogas qua vieram a ser recebidas pelo cristianismo, quais sejam o tabaco, o chocolate e a quinina (também conhecida como quina, embora este, propriamente, seja o nome da planta da qual se extrai a quinina). Exatamente pelo fato de haverem elas sido consideradas aceitas por católicos, seu consumo encontraria salutar resistência na Europa protestante. Deveras, chegou-se a crer que a quinina, cujas potencialidades curativas haviam sido aprendidas por jesuítas ibéricos com nativos do Peru ${ }^{93}$ e que, portanto, fora por aqueles levada ao continente europeu, seria "uma diabólica invenção, um veneno a ser utilizado com o fim de exterminar todos os não-católicos" "94, a ponto de o puritano e protestante radical Oliver Cromwell, no auge de seu poder sobre a Inglaterra, haver preferido sucumbir à malária a remediar-se com tal “droga católica”, no ano de $1658^{95}$.

Tendo se tornado, no século XVII, os maiores comerciantes internacionais do mundo, os holandeses então passaram a liderar a distribuição de álcool e de tabaco. Através da ampliação dos mercados possibilitada pela expansão de seus negócios em diferentes continentes, disseminou-se internacionalmente o consumo de bebidas alcoólicas como a vodca, o uísque e o rum, ademais do já culturalmente sólido consumo do vinho. Posteriormente, também a uva passaria a ser destilada, originando-se daí o conhaque. E, anos depois, a subjugação econômica

92 CARNEIRO, Henrique. Filtros, mezinhas e tríacas: as drogas no mundo moderno. São Paulo: Xamã, 1994, pp. 42-43.

93 LINT, Jennifer. "Chloroquine". Disponível [on-line] em: http://www.stanford.edu/group/parasites/ParaSites2005/Chloroquine. Acesso em: 03/01/2009.

94 "Treatment of malaria - a brief history of antimalarials". Disponível [on-line] em: http://www.mmv.org/pages/content_frame.asp?ThePage=page1_000400010002_1.htm\&Nav=000400 010002. Acesso em: 31/05/2006. Trad. livre.

95 SNEDEN, Albert T. "Alkaloids". Disponível [on-line] em: http://www.people.vcu.edu/ asneden/alkaloids.htm. Acesso em: 03/01/2009. 
definitiva de Portugal pela Inglaterra seria materializada tendo o vinho como objeto do Tratado de Methuen ${ }^{96}$, em 1703.

Outro dado revelador da consolidação da importância econômicosocial adquirida por psicoativos àquele tempo reside no fato de que a Revolução Francesa de 1789 teve igualmente, entre as circunstâncias que precipitaram a sua eclosão, a rejeição da população à alta taxação do vinho. De fato, além de outras funções comerciais e de defesa, os muros que circundavam a capital francesa igualmente visavam a obstar a entrada de vinho que não possuísse o devido controle do governo e das respectivas corporações de ofício - e que tenderia a ser, portanto, mais barato.

Em meio a todas as drogas cujo uso se disseminou desde a expansão do mercantilismo, as que se tornariam mais bem recebidas culturalmente viriam a ser o tabaco e a cafeína. E, dentre as explicações que se obtiveram para seus sucessos, revelou-se importante o fato de ambas constituírem substâncias mais adaptadas à própria lógica econômica capitalista, seja em decorrência de seu processo produtivo mesmo, realizado segundo a então dominante técnica de produção agrícola - o plantation $^{97}$-, seja por seu efeito estimulante aumentar a capacidade de vigília e a disposição laboral humanas. Especialmente quando mascado, mas também quando fumado, o tabaco reduz igualmente as sensações de fadiga e de fome - o que, evidentemente, convinha a sociedades que pretendiam fazer seus trabalhadores dedicarem tempo máximo às suas respectivas atividades produtivas. E os efeitos da cafeína, sabe-se, são em grande medida semelhantes nesse particular.

\subsection{Século XIX: disseminação do consumo e conseqüente crise social}

Conquanto a criminalização das condutas associadas à venda e ao consumo de psicoativos tenha nascido, salvo em casos excepcionais ${ }^{98}$, com o século

\footnotetext{
96 Também conhecido, no idioma português, como Tratado de Panos e Vinhos.

97 Técnica de produção agrícola baseada na monocultura de exportação, comum em todo o Continente Americano entre os séculos XVI e XIX.

98 De que constituem exemplos algumas municipalidades e estados norte-americanos, onde o tratamento penal da matéria exsurgiu a partir de meados do século XIX. A respeito, vide: ESCOHOTADO, Antonio. Historia general de las drogas, $3^{\mathrm{a}}$ ed. Madrid: Espasa, 2000, p. 505.
} 
$\mathrm{XX}$, foi nos oitocentos que teve início o processo de acentuada estigmatização das substâncias e de seus usuários, que forneceria bases suficientes para o definitivo ingresso da matéria nas legislações penais de todo o mundo, que lhe seria conseguinte.

No início do século XIX já ocorriam com alguma freqüência estudos e debates entre médicos e cientistas europeus acerca da imposição de restrições ao uso de psicoativos. Remanescia o ópio a droga mais consumida, comumente através do medicamento laudanum (cuja composição havia muito deixara de ser a mesma da mistura de Paracelsus, mas mantivera a preponderância do derivado da papoula) que, como substância medicinal, havia tempos continuava a aliviar e a causar enfermidades conforme era utilizado ${ }^{99}$. Outrossim, remanesciam bastante controversas as conclusões dos pertinentes estudos - como, de resto, nunca deixou de suceder. De todo modo, já àquele tempo, logrou-se observar que as reações individuais ao uso do ópio se mostravam, por vezes, bastante idiossincráticas ${ }^{100}$.

Momento considerado divisor de águas para o modo com que o ocidente encarou a questão foi a publicação, nos anos de 1820, da obra The Confessions of an English opium eater ${ }^{101}$. Seu autor, Thomas De Quincey, fora criado sob o moralismo vigilante de sua mãe, e inicialmente utilizou-se do ópio para tratar um problema de nevralgia, malgrado também o houvesse consumido acredita-se - como espécie de represália ante a severa educação que recebera ${ }^{102}$. Após algum tempo, passou a utilizar-se recreativamente da substância, sobretudo quando estava a assistir óperas e outros concertos musicais, os quais ele afirmava apreciar com um "prazer sensual" quando sob efeito do ópio ${ }^{103}$; igualmente, passou a apreciar caminhadas por regiões pobres e guetos de sua cidade natal, Londres, sob efeito do uso do psicoativo. Mais tarde, mudou-se para Edimburgo, onde viveu ladeado pela intelectualidade da efervescente capital escocesa - em que muitos de

${ }^{99}$ DAVENPORT-HINES, Richard. The pursuit of oblivion: a global history of narcotics. London New York: W. W. Norton, 2002, p. 41.

${ }^{100}$ Tome-se como exemplo comparativo o fato de que, para o novelista escocês Walter Scott, 60 gotas de laudanum (por ele utilizado para combater dores estomacais) eram bastantes para causar forte sentimento de ressaca e dores de cabeça, ao passo que, para o magistrado inglês John Harriot, 80 gotas do mesmo medicamento nada causavam senão uma leve tontura. Idem, ibidem, p. 68.

${ }^{101}$ Publicada no Brasil sob o título Confissões de um comedor de ópio (DE QUINCEY, Thomas. Trad. Ibañez Filho. Porto Alegre: L\&PM, 2002).

${ }^{102}$ DAVENPORT-HINES, Richard. Op. cit., p. 68.

${ }^{103}$ Idem, ibidem, p. 68. 
seus ilustres membros eram usuários de ópio. Embora ali houvesse sido considerado alguém de sociabilidade prodigiosa, não tardou a ser acometido por males como a privação financeira e a depressão, os quais foram potencializados pelo uso contumaz do laudanum; retornou, então, à capital do Reino Unido em estado de penúria ${ }^{104}$. Destarte, suas Confissões, que ecoaram por décadas em todo o continente, constituem um retrato melancólico de vida que, mesmo tendo se tornado desde cedo literatura cult $^{105}$, encontrava-se resolutamente fora dos padrões e valores britânicos mais caros de seu tempo, os quais atingiriam seu ápice no período vitoriano - então prestes a se iniciar.

$\mathrm{Na}$ mesma centúria, o império britânico ver-se-ia envolvido em diversos conflitos decorrentes de sua condição de potência capitalista dominante. Entre eles, sucedeu a chamada guerra do ópio, travada contra a China entre 1839 e 1842, após o governo chinês haver vetado a entrada em seu país do ópio britânico cultivado na Índia e inutilizado os estoques do produto mantidos no porto de Cantão - o que ia de encontro aos interesses dos britânicos, que se subsidiavam nas doutrinas econômicas liberais para se aproveitar maximamente de todo comércio internacional, malgrado já fosse o ópio objeto de consideráveis restrições em território metropolitano ${ }^{106}$. O conflito sino-britânico encerrar-se-ia com a assinatura do Tratado de Nanquim, que impunha severas sanções pecuniárias à China, bem como determinava a abertura de seus portos para o livre comércio internacional e a concessão aos britânicos da cidade de Hong Kong, importante porto e entreposto comercial. Não houve, no texto do $\operatorname{tratado}^{107}$, qualquer menção explícita à mercancia do psicoativo, mas somente referências genéricas ao comércio como um todo, ainda que se conhecesse a preponderância do ópio naquele comércio - cumpre lembrar, substância cuja livre produção e distribuição já se via altamente contestada na metrópole. Haveria ainda outro entrevero entre os dois países entre os anos de 1856 e 1858, que foi considerado por historiadores como uma continuação do conflito anterior, e que se encerraria com a ocupação de Pequim por tropas aliadas inglesas e

\footnotetext{
${ }^{104}$ Idem, ibidem, p. 69.

${ }^{105}$ Idem, ibidem, p. 61.

106 Anota Escohotado que, curiosamente, o Reino Unido fundou sua declaração de guerra em um "intolerável atentado contra a liberdade de comércio", supostamente cometido pelos chineses. ESCOHOTADO, Antonio. Historia general de las drogas, $3^{\mathrm{a}}$ ed. Madrid: Espasa, 2000, p. 531.

107 Disponível [on-line] em: http://www.international.ucla.edu/eas/documents/nanjing.htm. Acesso em: 03/01/2009.
} 
francesas, resultando em sanções e concessões ainda maiores a que se obrigava a China ${ }^{108}$.

Em meados do século XIX, o consumo de ópio, em grande medida estimulado por pressões internacionais de índole comercial, já se tornara algo bastante arraigado em terras chinesas. E, por decorrência das sucessivas crises econômicas nacionais, muitos de seus habitantes puseram-se a emigrar para regiões da Europa, Estados Unidos e Austrália. Ali viveriam no mais das vezes em condições miseráveis, frequientemente reunidos em guetos nas periferias das grandes cidades, locais em que o uso do ópio resultava bastante corriqueiro. Isso contribuiu notavelmente para a estigmatização dos consumidores do psicoativo, a despeito do fato de os capitalistas dos países hospedeiros auferirem elevados e reiterados lucros com o comércio internacional do mesmo produto; a seu turno, o estigma então forjado nos países centrais contribuía para a exclusão social dos chineses, muitas vezes apontados como causadores de um contágio do uso que supostamente levava ao crescimento do consumo da droga e da delinqüência naqueles países ${ }^{109}$. Por consequiência, reputados como danosos usuários de ópio, viram-se os chineses vítimas de preconceito explícito que, anos mais tarde, culminaria com a edição, nos Estados Unidos, do Chinese Exclusion Act ${ }^{110}$, restringindo-se-lhes a imigração - a qual passava a ser permitida apenas para ricos, acadêmicos e profissionais altamente qualificados ${ }^{111}$. Referida norma teve império na auto-proclamada terra das liberdades e oportunidades até a metade do século XX.

Como imigrantes pobres que eram nos EUA, chineses viviam confinados em guetos onde se criava ambiente propício à proliferação de casas de distribuição de drogas, além de casas de jogo e de prostituição - como, de resto, é comum a periferias de centros urbanos. É de se supor, pois, que o uso recreativo se espalhava entre eles também por carecerem de quaisquer outros meios de recreação para os momentos em que se vissem fora do ambiente de trabalho, sendo que era nas

\footnotetext{
108 Objeto do Tratado de Tientsin, de 1858. A respeito, vide: ESCOHOTADO, Antonio. Historia general de las drogas, $3^{\mathrm{a}}$ ed. Madrid: Espasa, 2000, pp. 531-532.

${ }_{109}$ Idem, ibidem, pp. 550-552; DAVENPORT-HINES, Richard. The pursuit of oblivion: a global history of narcotics. London - New York: W. W. Norton, 2002, pp. 178-179.

${ }^{110}$ Lei federal editada em 1896 nos EUA, cuja vigência perdurou até o ano de 1942.

${ }^{111}$ DAVENPORT-HINES, Richard. Op. cit., p. 179.
} 
casas de jogo, de prostituição e/ou de distribuição e consumo de drogas que imigrantes interagiam entre si e com os demais habitantes de seu entorno geográfico.

Por outro lado, a notável disciplina laboral e diligência dos chineses, fossem ou não consumidores de ópio, causava forte descontentamento por parte de unidades sindicais, insatisfeitas com a conseqüente desvalorização do mercado de trabalho ${ }^{112}$. Aos poucos, então, as classes médias locais, perplexas em face de hábitos diferentes de grupos que não reconheciam como concidadãos, começavam a preocupar-se, a exemplo do que já ocorrera com as elites britânicas, com sua vulnerabilidade ante o mal que o ópio passava a representar - menos por suas inegáveis potencialidades malévolas que pelo fato de seus consumidores representarem-lhes uma certa escória social.

Cite-se, ademais, que, ainda em meados do século XIX, começaram a surgir nos Estados Unidos associações moralistas voltadas à defesa do decoro e da sobriedade da sociedade local ${ }^{113}$. Seu advento seguiu-se a partir de dois fatores: a introjeção, na consciência coletiva dos americanos wasp $^{114}$, da noção de "pobreza culpável", que redundou na quebra das eficientes redes de assistência social até então dominantes $^{115}$, e o estabelecimento de um nexo causal entre pobreza, infelicidade e delinqüência com o consumo de álcool ${ }^{116}$. A retomada da religiosidade puritana e do nativismo, além de oposições à igualdade de direitos, favoreceram o surgimento dessas associações segregacionais, entre as quais se destacariam, por seu forte poder de influência e grande repercussão, a Woman's State Temperance Society e, mais ao

\footnotetext{
${ }^{112}$ ESCOHOTADO, Antonio. Historia general de las drogas, $3^{\mathrm{a}}$ ed. Madrid: Espasa, 2000, pp. 551553.

${ }^{113}$ ESCOHOTADO, Antonio. Op. cit., pp. 505 et seq.

114 Acrônimo anglófono para o etnônimo sociológico e cultural que designa os cidadãos brancos, anglo-saxões e protestantes (white, anglo-saxon, protestant), e simboliza um padrão de identidade nacional estadunidense.

115 Tradicionalmente, desde os tempos coloniais, a existência de pobres, doentes, debilitados física e mentalmente e mesmo vagabundos era vista como algo providencial para que os bons cristãos pudessem exercitar sua caridade, muitas vezes abrigando-os e assistindo-lhes diretamente em seu lar. A partir da década de 1820, a acelerada industrialização propiciou ao país um vertiginoso crescimento econômico, que não foi, entretanto, compartilhado pelos novos imigrantes que chegavam pela já desenvolvida consta do Atlântico, e que acabaram formando cinturões de pobreza em torno das grandes cidades. Então, as classes mais favorecidas e as autoridades, incapazes de compreender como tamanho desenvolvimento industrial poderia geral algo diferente de alegria e ordem, passaram a atribuir aos pobres a responsabilidade por seu próprio desfavorecimento, e a postular a sua segregação para o bem do corpo social. E, assim, surgem as instituições penitenciárias e manicômios como destinos de pobres, loucos, vagabundos, doentes, ébrios e anciãos indesejados. Idem, ibidem, pp. 498505.

${ }^{116}$ Idem, ibidem, p. 505.
} 
final do século, a Anti-Saloon League ${ }^{117}$. Tais grupos procuravam realizar espécie de limpeza social no território norte-americano, na medida em que para o puritanismo revelava-se imoral e inconcebível a possibilidade de se haver prazeres ainda em vida; ao revés, esta haveria de ser destinada ao trabalho, por meio do qual se chegaria ao único prazer real - a ser gozado na eternidade.

Emergia ali, tanto em áreas urbanas quanto em áreas rurais, uma cultura extremamente segregativa voltada à marginalização da pobreza e de minorias étnicas que, ao pretender abarcar toda sorte de potenciais desviados, utilizava-se do álcool como fator inclusivo para pessoas que não necessariamente se encaixavam nos demais estereótipos - loucos, doentes, delinqüentes, anciãos - passíveis de segregação. Ao mesmo tempo, a custódia dessa massa de desviados revelar-se-ia bastante conveniente ao interesse dos capitalistas industriais, porquanto internatos e penitenciárias, ainda nascentes, guardavam uma reserva de mão-de-obra que quase não lhes importava $\operatorname{custos}^{118}$. Encontrava, pois, seus limites o liberalismo norteamericano, na medida em que conviesse aos interesses de grupos de pressão relevantes excluir determinadas populações do convívio social:

[...] o Estado renunciava a soluções não segregativas para abordar o problema da desviação espiritual ou somática com métodos estritamente opostos, pois que recluindo pessoas em reformatórios, casas de correção, hospícios, manicômios e cárceres adicionava à marginalização primária uma marginalização secundária. As causas eleitas para explicar a desviação eram a indolência e a intemperança com o álcool, quando uma e outra coisa podiam ser interpretadas com o mesmo ou maior fundamento como meros sintomas das aceleradas transformações sociais que o país experimentava. Para ser exato, o único fator realmente comum aos desviados que tanto inquietavam era [o de] serem não-proprietários, mas isso foi insistentemente omitido pela mentalidade empresarial, capelães, diretores de centros de internação e até câmaras legislativas. Abandonara-se o princípio do laissez faire ao assumir a administração central funções antes descentralizadas e privatizadas [...]. Em outras palavras, para que pudesse florescer esse novo capitalismo [industrial] era preciso fortalecer mecânicas de controle social antes desconhecidas, apresentando os conseqüentes como antecedentes onde fosse oportuno, como aconteceu com o álcool ${ }^{119}$.

${ }^{117}$ Idem, ibidem, pp. 505-509.

${ }^{118}$ Idem, ibidem, pp. 501-504.

${ }^{119}$ Idem, ibidem, pp. 503-504. Trad. livre. 
Criavam-se assim as bases para o surgimento e ascensão até mesmo de um partido político anti-álcool, o Partido Proibicionista, fundado em 1869, que, mesmo minoritário, viria a exercer uma influência espetacular sobre a política norteamericana, e que seria sustentado, fundamentalmente, por moralistas puritanos, políticos eleitoralistas e por empresários incomodados com o absenteísmo laboral provocado pelo consumo de álcool ${ }^{120}$. Aos poucos, a cultura fortemente moralista que então predominava nas nações anglo-saxônicas, e notadamente nos EUA, fazia com que se abrissem cada vez mais os caminhos para o influxo do proibicionismo.

\subsection{O século XX e o influxo do proibicionismo}

De modo geral, até fins do século XIX, a produção e a distribuição de substâncias psicoativas nos mais diferentes países eram, em regra, livres, logo não submetidas a qualquer sorte de controle estatal em todo o planeta. Remanesciam interesses internacionais relevantes sobre a comercialização de tais substâncias, notadamente no caso do ópio - que, como visto, já motivara duas guerras devidas à oposição britânica ao viés proibicionista chinês - e de substâncias cuja possibilidade de produção em escala industrial já eram conhecidas e exploradas ${ }^{121}$. O centro econômico do mundo ainda era a Europa, e, portanto, de lá provinham os princípios éticos, econômicos e científicos que balizavam as discussões respeitantes. No entanto, na virada do século, e com base na doutrina de internacionalização dos princípios morais dominantes de sua política interna, uma potência econômica emergente começaria a se apresentar como líder na defesa do proibicionismo na cena diplomática internacional: os Estados Unidos da América ${ }^{122}$.

\footnotetext{
${ }^{120}$ Idem, ibidem, pp. 505-509. Ao mencionar o sólido apoio da classe política ao proibicionismo emergente, lembra o autor que os mesmos próceres políticos que publicamente coincidiam em temer a degeneração etílica da América, poderiam permitir-se, ocasionalmente, consumir suas doses de álcool em privado. Ibidem, p. 507.

121 Lembre-se que, desde a segunda metade dos Oitocentos, grandes laboratórios farmacêuticos europeus e norte-americanos como Merck, Bayer, Hoffmann-La Roche e Parke Davis já lucravam com a produção e distribuição de drogas como a morfina, a heroína e a cocaína.

${ }^{122}$ Malgrado hajam sido os EUA o primeiro país do mundo a promulgar uma constituição inspirada nos princípios políticos liberais, é certo que seu povo incorpora, desde suas origens, uma cultura de severa intolerância, herança de sua rigorosa fé e costumes puritanos, razão por que o último grande processo contra bruxas se daria precisamente em Massachusetts, num tempo em que europeus já se espantariam com práticas oficiais semelhantes (ESCOHOTADO, Antonio. Historia general de las drogas, $3^{\text {a }}$ ed. Madrid: Espasa, 2000, p. 495). Destarte, observou Tocqueville, ao analisar a formação
} 


\subsubsection{Moralismo puritano e higienização social como fundamentos de elaboração de políticas legais repressivas}

Desde o final do século XIX até toda a extensão do século $\mathrm{XX}$, podese afirmar que a doutrina da proibição apresentaria cinco principais vetores ideológicos - a saber, em ordem cronológica, a práxis moralista, a saúde pública, a segurança pública, a segurança nacional e, por fim, o proibicionismo militarista ${ }^{123}$.

Como visto, nos últimos decênios do século XIX, a formação de grupos sociais de índole moralista em cidades norte-americanas forneceu um ambiente cultural e político propício ao florescimento e amadurecimento das teses proibicionistas. Nesse mister, merece especial referência a já citada Anti-Saloon League. Criada em 1895, tal associação tencionava, como o seu próprio nome denota, trabalhar contra a existência dos saloons, estabelecimentos espalhados pelo oeste do país que eram associados a três diferentes práticas (vícios) a que se visava combater: o consumo de álcool, o jogo e a prostituição ${ }^{124}$, reputados como comportamentos atentatórios ao moralismo puritano da classe média wasp nacional. A Anti-Saloon League, através de uma atividade política, lobística e propagandística intensa, logrou agregar, rapidamente, milhões de associados, pelo que, no início do século XX, nenhum político, democrata ou republicano, ousaria desafiar "sua exigência de uma América limpa" ${ }^{, 25}$.

Havia, não obstante, a identificação de certas substâncias a grupos sociais específicos - o que evidenciava o conteúdo étnico da citada limpeza. Assim, associavam-se a cocaína aos negros (que alegadamente, após seu consumo, punham-

da sociedade norte-americana e de suas instituições, (i) a incessante vigilância ali existente sobre os domínios da consciência, tamanha a preocupação dos legisladores com "a manutenção da ordem moral e dos bons costumes da sociedade" através de normas penais, e (ii) a freqüente identidade entre pecado e delito verificada nas primeiras compilações legislativas da Nova Inglaterra. Daí o fato de, por exemplo, em 1650, o Código de Connecticut haver pioneiramente lançado à ilicitude a embriaguez e a vadiagem, e, em 1660, uma jovem ter sido condenada por haver dito "palavras indiscretas" e haver permitido beijar-se. TOCQUEVILLE, Alexis de. De la démocratie en Amérique, t. I, 12 $2^{\mathrm{a}}$ ed. Paris: Pagnerre, 1848, pp. 58-60. Trad. livre.

${ }^{123}$ RODRIGUES, Thiago. Comunicação pessoal, out/2003.

${ }^{124}$ ESCOHOTADO, Antonio. Op. cit., p. 509.

${ }^{125}$ Idem, ibidem, p. 509. 
se a estuprar mulheres brancas ${ }^{126}$ ), a maconha aos latino-americanos (notadamente os mexicanos, de mais numerosa presença nos EUA) ${ }^{127}$, o ópio aos chineses e o álcool aos irlandeses ${ }^{128}$. Deveras, iniciado o século XX, vão se tornando cada vez mais fortes em terras norte-americanas as idéias de higiene social, a xenofobia e a própria eugenia $^{129}$, em grande medida graças ao notável desempenho de próceres que mais tarde passariam a ser conhecidos pela sociologia norte-americana como moral enterpreneurs $^{130}$.

Em 1906, edita-se o Food and drug Act, que, efetivamente, nada proibia, mas apresentou grande importância simbólica por haver significado a primeira ocasião em que um ato legislativo de alcance nacional considerava expressamente a questão das drogas, regulando-as administrativamente. A lei não foi suficiente para contentar os partidários da proibição, grupo que no início do século XX passava a incluir, cada vez mais, médicos e suas associações de classe,

${ }^{126}$ DAVENPORT-HINES, Richard. The pursuit of oblivion: a global history of narcotics. London New York: W. W. Norton, 2002, pp. 199-201.

${ }^{127}$ Idem, ibidem, p. 201-202.

${ }^{128}$ ESCOHOTADO, Antonio. Op. cit., p. 607. A despeito de sua origem européia, os irlandeses se viram socialmente excluídos nos EUA em razão de sua religião ser predominantemente católica, o que também constituía motivo de conflitos na Grã Bretanha. Nesse mister, anota Escohotado que, nos tempos de Cromwell e das treze colônias, irlandeses haviam sido negociados como escravos no mercado da Virgínia. Ainda, quanto aos chineses, o mesmo autor relembra que, para os sindicatos, tinham eles o vício adicional de trabalhar mais e por menos dinheiro que os americanos. Ademais, ao mesmo tempo em que se consagravam tais identificações étnico-farmacológicas, drogas extremamente destrutivas e que consumiam a saúde de milhões de pessoas mas cujo uso não era identificado com nenhuma minoria indesejada, como os barbitúricos, permaneceriam por mais de meio século livres, em absoluto, de qualquer estigma social ou controle legal (idem, ibidem, pp. 607-608).

${ }^{129}$ Lembre-se ainda que, posteriormente utilizada em larga escala pela medicina nazista alemã, a eugenia parece ter surgido nos EUA exatamente nesses tempos de virada de século. E ali chegou a se tornar precedente jurisprudencial constitucional, em célebre decisão da Suprema Corte datada de 1927; ao discutir a validade de uma das muitas leis estaduais de esterilização compulsória de pessoas consideradas inferiores, proclamou o Justice Oliver Wendell Holmes Jr. em seu voto condutor: "é melhor para todos que, em vez de esperar para executar descendentes degenerados por crimes, ou deixar que morram de fome por causa de sua imbecilidade, a sociedade possa impedir os que são claramente incapazes de continuar a espécie [...]. Três gerações de imbecis são o bastante" (Buck v. Bell, 1927. Trad. livre). Naqueles tempos, cerca de 65 mil pessoas foram esterilizadas compulsoriamente por apresentarem males como epilepsia ou debilidade mental, sendo que, na escolha de pacientes a serem submetidos à esterilização, muita vez concorriam fatores raciais ou sociais - semelhantes àqueles que também concorreram para a escalada das políticas proibicionistas sobre drogas, sucedida, como visto, no mesmo contexto histórico-político.

${ }^{130}$ ESCOHOTADO, Antonio. Op. cit., p. 608. Acerca do conceito de empresários morais, vide: BECKER, Howard Saul. Outsiders: studies in the sociology of deviance. New York: The Free Press, 1997, pp. 147-164; mais sucintamente, em nossa literatura jurídica: ZAFFARONI, Eugenio Raúl; BATISTA, Nilo; ALAGIA, Alejandro; SLOKAR, Alejandro. Direito penal brasileiro, vol. I, $2^{\mathrm{a}}$ ed. Rio de Janeiro: Revan, 2003, p. 45. 
interessados sobretudo em que se lhes estabelecesse o monopólio da prescrição de fármacos, ampliando o mercado de sua profissão ${ }^{131}$.

No cenário internacional, o pretexto de missão civilizatória que legitimava as ambições imperialistas norte-americanas mostrou-se, na virada do século, de grande utilidade para que andassem em paralelo a sua expansão comercial e a exportação do moralismo puritano ${ }^{132}$.

Nesse contexto, uma vez que o Chinese Exclusion Act ensejara boicotes chineses a produtos americanos, e vendo seus empresários preocuparem-se com a possível perda de um mercado potencial de 400 milhões de pessoas, os Estados Unidos houveram por convocar uma conferência internacional em Xangai para discutir a interdição do ópio. Alegaram, como pretexto para a reunião, a necessidade de se proteger a China e seu povo contra os males da citada droga, a partir do que pretenderiam abolir a sua produção e comercialização em outras terras. A conferência, ocorrida em 1909, não logrou o efeito almejado, apesar dos esforços retóricos dos americanos: delegados europeus, mais informados farmacologicamente e que argumentavam sob uma perspectiva laica, não compreendiam como o mais tradicional remédio para tantas moléstias pudesse resultar "maligno e imoral"; a Turquia nem mesmo compareceu, ao passo que a Pérsia enviou um traficante de ópio como seu representante oficial; por fim, a China - o país a que se tencionava socorrer - já equacionara problemas de insubordinação civil e de corrupção motivados por sua política proibicionista anterior. Encerrou-se a conferência com a aprovação de recomendações (e não resoluções, como queriam os americanos), das quais apenas duas iam ao encontro parcial dos interesses de seus fomentadores - uma que instava

\footnotetext{
${ }^{131}$ ESCOHOTADO, Antonio. Historia general de las drogas, $3^{\mathrm{a}}$ ed. Madrid: Espasa, 2000, pp. 603607. Aponta o autor que o discurso do alto risco à saúde pública foi então introduzido nos debates por tais profissionais e pela American Medical Association, que se arrogavam mais autorizados a discutir $\mathrm{o}$ assunto malgrado estudos científicos a respeito ainda se revelarem inconclusivos.

${ }^{132}$ Com efeito, é possível afirmar que as teses do destino manifesto e da doutrina Monroe (e, pouco após, a releitura desta à luz do big stick de Theodore Roosevelt) desempenharam papel relevante na justificação do protagonismo americano no movimento internacional contra o ópio e outros vícios iniciado com o século XX. Nessa medida, em tempos em que missionários exerciam acerca do ópio uma influência jamais vista sobre a opinião pública e a política oficial estadunidense, autoridades logo constataram que a imposição de sua fé e cultura a outras nações, inicialmente através de um empreendimento cristão, revelar-se-ia um empreendimento altamente rentável. Idem, ibidem, pp. 608617.
} 
governos à gradual supressão do ópio fumado, e outra, a que não se exportasse ópio a nações cujas leis proibissem sua importação ${ }^{133}$.

De toda sorte, é inegável que a Conferência de Xangai constitui um marco evolutivo para a doutrina e as políticas da proibição, por haver inaugurado a lista dos muitos encontros diplomáticos internacionais com o mesmo fim - e que se mostrariam bastante exitosos e raramente contestados.

Igualmente estimulada pela diplomacia estadunidense, ocorreu, entre 1911 e 1912, a Conferência da Haia, onde surgiriam as primeiras deliberações internacionais no sentido da proibição de drogas. Ali se firmou a idéia de o uso médico constituir a única justificativa legítima para a utilização de psicoativos como o ópio, a morfina e a cocaína (e derivados), e se estabeleceu que as partes contratantes comprometer-se-iam a aprovar legislações restritivas em âmbito interno. Todavia, inúmeros foram os impasses disso decorrentes, ora porque potências aceitavam restringir apenas fármacos que não produziam, ora porque se recusavam a firmar trechos em que a assunção de compromissos pudesse beneficiar potências concorrentes que se haviam ausentado da conferência - e que, portanto, não seriam signatárias do acordo $^{134}$. Conseqüentemente, negociações foram suspensas e a conferência teve de ser retomada nos dois anos posteriores, sendo que, dos signatários de 1914, somente cinco cumpririam o acordo de aprovar legislações proibitivas internas $^{135}$.

A primeira lei federal norte-americana a controlar a distribuição de psicoativos, o Harrison Act ${ }^{136}$, foi promulgada em 1914 como decorrência direta das conversações travadas na Haia, vindo a abarcar, deste modo, particularmente opiáceos e derivados de coca, e a consagrar o princípio de que somente era aceitável

\footnotetext{
${ }^{133}$ Idem, ibidem, pp. 617-621. Vale anotar que a Turquia, então maior produtor mundial do psicoativo, em resposta à proposição americana de realização imediata de uma nova conferência, prometera formalmente não participar de reuniões em que se enviassem missionários para tratar de economia e farmácia (ibidem, p. 621).

${ }^{134}$ Idem, ibidem, pp. 627-631. Note-se a inelutável prevalência de razões econômicas nas discussões que, alegadamente, pretendiam tutelar uma suposta saúde pública. Ao cabo, os acordos que houve fundaram-se em concessões econômicas cruzadas entre as potências preponderantes.

${ }^{135}$ EUA, China, Holanda, Noruega e Honduras.

136 Concebido preliminarmente pelo congressista democrata Francis Burton Harrison, tal diploma legislativo foi aprovado após pouquíssimas discussões públicas e quase nenhuma cobertura dos meios de comunicação (DAVENPORT-HINES, Richard. Op. cit., p. 213).
} 
- e moral - o uso médico dessas substâncias, e devidamente controlado pelos respectivos profissionais; jamais qualquer outra forma de uso.

Fruto do parco amadurecimento do estudo da matéria e do atropelo legislativo que culminou em sua aprovação, o Harrison Act apresentou um texto confuso $^{137}$, que não deixava claro se se tratava de meras regulamentações administrativas e tributárias ou de normas de direito material (e penal) ${ }^{138}$. Por essa razão, dificuldades de aplicação prática da norma - cuja fiscalização incumbiu à fazenda, e não à polícia - eram inevitáveis ${ }^{139}$, e mesmo a Suprema Corte precisou de mais de uma apreciação de caso para, pressionada pelo governo, reconhecer sua constitucionalidade $^{140}$. Cabe assinalar, porém, que, a partir do início da década de 1910, a bancada proibicionista no Congresso crescia sistematicamente após cada eleição proporcional, evidenciando haver um considerável nicho eleitoral para tal discurso; assim, uma proibição mais explícita, que reclamava uma reforma constitucional ainda não possível em 1914, não tardaria a chegar.

Do outro lado do Atlântico, a hostilidade britânica para com a cocaína crescera com a eclosão da Primeira Grande Guerra. Os alemães, que rivalizavam com os britânicos em suas práticas imperialistas e em sua tardia mas acelerada industrialização, eram vistos por eles como os grandes detentores da produção dessa droga, e seus laboratórios haviam relevante mercado consumidor no Reino Unido. A cocaína, então, veio a ser considerada inimigo de guerra, tal qual o Estado alemão também o era ${ }^{141}$.

Terminado o conflito, as forças aliadas, entre outras exigências impostas aos derrotados, incluíram a ratificação dos acordos lavrados na Conferência

\footnotetext{
${ }^{137}$ Como, de resto, seria comum à generalidade das legislações proibitivas que se criariam em todo o mundo nas décadas subsequientes.

${ }^{138}$ ESCOHOTADO, Antonio. Historia general de las drogas, $3^{\mathrm{a}}$ ed. Madrid: Espasa, 2000, pp. 636644.

${ }^{139}$ Idem, ibidem, pp. 641-644.

${ }^{140}$ Caso United States v. Doremus, julgado em 1919.

141 O fenômeno da estigmatização dos fármacos produzidos na Alemanha, notadamente aqueles baseados em cocaína e heroína, repetir-se-ia nos EUA - que entrariam na guerra pouco mais tarde -, onde a penetração de tais compostos passaria a ser vista como "uma conspiração germanófila para escravizar o incauto usuário" (ESCOHOTADO, Antonio. Op. cit., p. 434). Ressalve-se aqui, todavia, a constatação de Escohotado quanto às falsas informações - ora exaltando propriedades inexistentes, ora omitindo graus de danosidade e letalidade - contidas em materiais de propaganda e mesmo em artigos com que laboratórios como Bayer, Merck e Parke Davis visavam a difundir o uso de alcalóides manufaturados. Op. cit., pp. 433-434; 455-457.
} 
da Haia, a que a Alemanha ainda resistira. Destarte, o tratado de paz de Versalhes, de 1919, por sugestão da diplomacia inglesa ${ }^{142}$, fez expressa referência em seu art. 295 ao dever de todas as partes fazerem valer aqueles acordos, inclusive aprovando sem demora a legislação interna que a tanto fosse necessária ${ }^{143}$. Tais circunstâncias concorreram para que, a partir de então, usuários de drogas passassem a ser vistos como criminosos não somente nos EUA, mas também na Europa. Desta forma, ainda no início do século XX, o mundo se via, cada vez mais, diante da definitiva escalada do proibicionismo.

De volta à América, ainda no ano de 1919 ocorreria fato de extrema importância simbólica: no caso Webb et al. v. The United States, decidiu a Suprema Corte que médicos não poderiam prescrever opiáceos para tratar pacientes já viciados, ainda que não houvesse outra forma de tratamento para drogaditos. Essa decisão, naturalmente precedida de intensa campanha moralista ${ }^{144}$, fez com que consultórios médicos passassem a ser invadidos e fechados por agentes federais e muitos de seus titulares fossem processados criminalmente como instigadores do vício $^{145}$; médicos renomados que ousaram pronunciar-se publicamente contra a irracionalidade da proibição foram perseguidos e estigmatizados, tiveram suas carreiras arruinadas e chegaram a ser processados por "conspiração para violar o direito vigente" ${ }^{, 146}$. A seu turno, o mass media nascente

servia sensacionalismo puro e simples: os temas favoritos eram negros cocainizados até a exasperação, chineses em sinistros fumatórios, mexicanos entre orgias e maconha, morfinômanos alemães com afãs revanchistas e, quanto ao álcool, as conhecidas acusações a irlandeses e italianos $^{147}$.

Afigurava-se, então, concluído o cenário para a definitiva interdição federal dos narcóticos, novéis inimigos da tranqüilidade pública. Antes disso, porém,

\footnotetext{
${ }^{142}$ Idem, ibidem, p. 631.

${ }^{143}$ É de se notar que, a partir de então, praticamente todos os países do planeta se obrigariam a seguir disposições acordadas por alguns poucos em 1912.

${ }_{144}$ ESCOHOTADO, Antonio. Op. cit., p. 644.

145 Por vezes, agentes da repressão fingiam-se pacientes dependentes em consultas, para, após forçarem o recebimento de uma prescrição de narcótico, procederem à prisão e incriminação de médicos; outros estratagemas indutores também foram utilizados para o mesmo fim, o que era facilitado pelo fato de o delito ser de mero risco, sem lesão ou mesmo vítima definida. Idem, ibidem, p. 665-670.

${ }^{146}$ Idem, ibidem, pp. 644; 657-660.

${ }^{147}$ Idem, ibidem, p. 660.
} 
a sociedade estadunidense ainda haveria de se preocupar, particularmente, com a necessidade de limpar-se do álcool.

Na segunda metade da década de 1910, proposições legislativas contra o uso do álcool já eram recorrentes, embora houvessem permanecido obstadas por grupos políticos mais liberais, sendo que o consumo da bebida era hábito de muitas autoridades de todos os poderes. O cenário político, de todo modo, endurecera com o envolvimento americano na guerra, e fatores díspares como a vitória militar na Europa, conflitos sindicais internos, revoltas operárias, a revolução bolchevique na União Soviética e as pressões exercidas por grupos proibicionistas, ao exacerbarem o nacionalismo e o messianismo do povo americano, criariam um terreno fértil para o recrudescimento legislativo; enquanto isso, usuários de drogas foram incluídos em um complexo clichê que abrangia germanofilia, barbárie e crime ${ }^{148}$. Por conseguinte, em 1919, em conformidade com a tendência respeitante manifestada pela sociedade norte-americana, entrava em vigor a $18^{\mathrm{a}}$ emenda à Constituição do país, permitindo a restrição de liberdades públicas até então intocadas. Exsurgiria, um ano após, o Volstead $A c t^{149}$, ou "lei seca", que proibia, sob penas de multa e prisão, todo o ciclo de produção, estocagem, comercialização, exportação e importação de álcool, designando portanto o seu absoluto banimento.

Para os artífices da lei seca, sua entrada em vigor em janeiro de 1920 significaria o nascimento de uma nova nação, de costumes limpos e espíritos sóbrios, livre de guetos, de cárceres e casas de correção vazios e de alegrias plenas para homens, mulheres, e crianças; mais que isso, fechar-se-iam "para sempre as portas do inferno" ${ }^{\prime 150}$.

Conforme se sabe, contudo, a lei seca revelou-se totalmente ineficaz para os fins a que se propôs, pouco tendo feito além de potencializar, em medida

\footnotetext{
${ }^{148}$ Idem, ibidem, pp. 644-645. Anota o autor, ainda que, grupos abstêmios opuseram-se à atitude de não-beligerância inicialmente defendida pelo presidente Wilson, tendo sido muito difundida em todo o país uma exaltação à guerra feita pela Anti-Saloon League, declarando que o hábito de beber "não apenas é criminógeno, ruinoso à saúde, corruptor da juventude e cusador de desunião marital, mas também germanófilo e traidor da pátria". Ibidem, pp. 646-647.

149 Assim alcunhada em homenagem ao seu principal arquiteto, o deputado republicano Andrew Volstead.

${ }^{150}$ VOLSTEAD, Andrew apud ESCOHOTADO, Antonio. Op. Cit., p. 648. Não se podendo justificar tamanha intervenção na liberdade pelos interesses econômicos em jogo, observe-se a que impressionante ponto o discurso moralista de limpeza social se revelava ingênuo, e, do ponto de vista político-legislativo, flagrantemente equívoco.
} 
extrema, o negócio ilegal. Deveras, nunca deixou de circular muito álcool em território norte-americano, e agora o álcool ilícito gerava novos problemas de saúde pública ao apresentar impurezas e, por vezes, nocividade letal ${ }^{151}$. Ainda, o mercado ilícito forjado pela proibição beneficiou diretamente o gangsterismo e as máfias, que, aproveitando-se do monopólio artificial, experimentaram crescimento exponencial ${ }^{152}$; e agigantou-se o aparato burocrático estatal voltado à repressão, com a criação de agências e outros órgãos especiais para a realização do controle pretendido $^{153}$. Como conseqüência, vertiginoso também resultou o crescimento da corrupção entre agentes oficiais ${ }^{154}$. Tudo isso sucedeu de modo crescente e sustentado até o ano de 1933, quando a aprovação da $21^{\text {a }}$ emenda implicou a abolição da lei seca.

Os resultados devastadores de quase uma década e meia de equívoco proibicionista-moralista, porém, não seriam facilmente contornados. A proibição do álcool lançara às margens da lei um enorme contingente populacional, com desastrosas implicações: além de haver ensejado a segregação e estigmatização de um sem-número de consumidores, o Volstead Act contribuiu para que associações criminosas crescessem e aprimorassem seus modi operandi - de execução e de organização territorial e financeira - de maneira notável ${ }^{155}$; afirma-se datarem desta época, inclusive, as primeiras práticas modernas de lavagem de valores ${ }^{156}$. Por fim, considera-se que a elevação de preço, a queda na qualidade e a dificuldade de obtenção de álcool havidas durante a proibição foram os principais responsáveis pela

\footnotetext{
${ }^{151}$ Segundo Escohotado, calcula-se que $10 \%$ do álcool industrial desnaturalizado dos EUA naqueles tempos foi desviado para produzir licores, e que houve cerca de 30 mil pessoas mortas por ingestão de álcool metílico e outras destilações venenosas, além de outros 100 mil com lesões permanentes como cegueira ou paralisia. Op. cit., p. 652.

${ }^{152}$ DAVENPORT-HINES, Richard. The pursuit of oblivion: a global history of narcotics. London New York: W. W. Norton, 2002, p. 226; ESCOHOTADO, Antonio. Op. cit., pp. 652-654.

${ }^{153}$ DAVENPORT-HINES, Richard. Op. cit., p. 230.

154 Dos cerca de 18 mil agentes inicialmente recrutados pela repressão ao álcool, 34\% foram identificados, onze anos depois, com notas desfavoráveis no exercício de sua função; aproximadamente $10 \%$ foram expelidos e processados por crimes de extorsão, roubo, furto, falsidade ideológica, tráfico e perjúrio; nem mesmo os ministros do interior e da justiça do presidente Harding deixaram de se envolver com contrabando e grupos criminosos. ESCOHOTADO, Antonio. Op. cit., p. 652.

${ }^{155}$ ESCOHOTADO, Antonio. Op. cit., pp. 652-653.

156 A respeito, anota Pitombo que a popularização da expressão money laudering possivelmente se deve à alegada prática, corrente em Chicago nos anos 20, de utilização das lavanderias locais por gangsters com o fito de ocultar o dinheiro obtido ilicitamente, conforme se manifestou Meyer Lansky, importante mafioso da época. PITOMBO, Antonio Sérgio Altieri de Moraes. Lavagem de dinheiro: a tipicidade do crime antecedente. São Paulo: Revista dos Tribunais, 2003, p. 32.
} 
emergência dos barbitúricos e pela explosão no consumo de maconha pela sociedade estadunidense verificados na primeira metade do século $\mathrm{XX}^{157}$.

Nos anos 20, todavia, consolidara-se irreversivelmente a repressão aos narcóticos, apesar de seus duvidosos resultados. A campanha mediática de estigmatização dos alcalóides e de seus usuários fora muito bem-sucedida, bem como a repercussão de declarações públicas deliberadamente exageradas de chefes da repressão interessados no aumento de seu orçamento ${ }^{158}$. A seu turno, seus agentes, no mais das vezes, preferiam a fácil tarefa de irromper-se contra inofensivos médicos e dependentes a arriscar-se contra mafiosos, o que, no entanto, tampouco livrou aqueles de serem objeto de chantagens e extorsões oficiais ${ }^{159}$.

Outrossim, fechadas as clínicas médicas, logo surgiam as vendas de morfina e cocaína nas ruas das cidades, a preços artificialmente elevados pela proibição e livres de qualquer tributação, e, graças às práticas heterodoxas desse novo mercado, cresciam os números de usuários e dependentes ${ }^{160}$. Convertidos em negócio altamente rentável e convidativo para transgressores, mitificados por setores sociais pobres e por determinados estratos sociais mais altos - especialmente os de

157 ESCOHOTADO, Antonio. Op cit., p. 769; DAVENPORT-HINES, Richard. The pursuit of oblivion: a global history of narcotics. London - New York: W. W. Norton, 2002, p. 239. A respeito, vale citar a observação precisa de Brecher: "Foi uma mudança legislativa, e não uma mudança na natureza humana, que estimulou a propaganda em larga escala do uso de maconha para fins recreativos nos Estados Unidos". BRECHER, Edward M. et al. The Consumers Union report on licit and illicit drugs. Boston: Little, Brown, 1972, 55.

${ }^{158}$ ESCOHOTADO, Antonio. Op. cit., p. 666.

159 Idem, ibidem, p. 670.

${ }^{160}$ Idem, ibidem, pp. 669-670. A título de comparação entre os tempos iniciais da proibição e tempos de sua vigência consolidada, expõe o mesmo autor: "[...] em 1928, a Narcotics Division $d a$ Proibition Unit tinha apenas 170 agentes em todo o país, numero insuficiente para acossar de modo eficaz boa parte dos usuários habituais. Esse tipo de usuário, chamado às vezes de southern white, abarcava um setor de classes médias formado por arrendatários, profissionais liberais, senhoras de idade, etc., $e$, até que a proibição não o estigmatizasse seguiria sendo um grupo normal de pessoas que nem sequer eram detectadas, na maioria dos casos, como usuários assíduos de drogas [...]. Sessenta anos depois, sem nenhum exagero, haverá cem vezes mais agentes dedicados à repressão, e cem vezes mais usuários de drogas proibidas. Nas mesmas cidades, uma investigação semelhante mostrará que a maioria dos adictos são adolescentes, todos laborativamente nulos e quase $90 \%$ autores de outros delitos, que por preços astronômicos injetam-se soluções dez ou vinte vezes menos puras, cuja alta freqüência de mortes por envenenamento se denomina eufemisticamente overdose. A evidência de aqueles 'adictos estabilizados', longevos e sem problemas de socialização, contrasta com a vida breve e a destrutividade dos pseudoadictos contemporâneos, consumidores de sucedâneos com parte de um ritual draculino que compra irresponsabilidade, porque as circunstâncias impostas pela lei à satisfação de seu vício assim sugerem. E, muito curiosamente, essas pessoas de média ou terceira idade que a princípios do século suportavam o hábito eram dope fiends, embora respeitassem escrupulosamente as leis, enquanto os que agora cometem parricídios para adquirir maisena ou estricnina com vagos rastros de um opiáceo são 'inocentes vítimas' precisamente do opiáceo, não do sistema específico que fomenta esse engano e esse envenenamento". Ibidem, p. 664. 
artes e moda -, opiáceos e cocaína floresceram com mais força que antes de 1914, quando eram propagandeados por grandes laboratórios. Mas em 1930, ao passo que inicialmente referira-se a números inexistentes para defender o recrudescimento, o comando repressivo negava o crescimento do problema. E o grupo de usuários antigos, predominantemente formado por cidadãos de classe média, maiores de quarenta anos e consumidores de preparados farmacêuticos, cedia lugar a jovens usuários de morfina, cocaína e heroína contrabandeadas, viventes nas periferias pobres de grandes cidades, dos quais cerca de dois terços eram negros e sulamericanos. Acossados pela repressão e pelos altos preços, traficavam para sustentarse, apresentando altos índices de cometimento de crimes comuns e absenteísmo laboral. Compunham minorias étnicas segregadas que, se por um lado utilizavam-se de drogas para tentar aliviar sua condição miserável, por outro haviam assimilado o estigma de usuários marginais ${ }^{161}$.

\subsubsection{Da sanidade social às ideologias da segurança}

Em 1930 surgiu o Federal Bureau of Narcotics (FBN), agência cujo escopo era cuidar das políticas de drogas em geral, executando as diretrizes repressivas correspondentes. Sua criação se deu precisamente após haver-se descoberto o envolvimento do filho e do genro do então principal chefe da repressão com um importante gângster de Nova Iorque, circunstância que impunha a imediata substituição de órgão e chefe ${ }^{162}$.

No limiar da nova década, seria a vez de a maconha tornar-se substância eleita como fonte anti-americana de perversão social, e incluída entre os "narcóticos" passíveis da mais feroz perseguição. Isso se deveu, em grande medida, ao fato de a imigração de mexicanos haver-se multiplicado nos anos 20 em estados do Sul e Oeste, atraídos pelo acelerado desenvolvimento econômico dos Estados Unidos. Sua mão-de-obra barata, a princípio - como sucedera com chineses -, foi bem acolhida por patrões, e contestada por sindicatos. Com a grande depressão, entretanto, passaram a constituir um indesejável excedente de bocas a serem

\footnotetext{
${ }^{161}$ Idem, ibidem, pp. 671-672.

${ }^{162}$ Idem, ibidem, p. 679.
} 
alimentadas em regiões assoladas por desemprego. Isso posto, fatores como (i) a preocupação dos proibicionistas em evitar sua desmoralização após a derrogação da lei seca e em prevenir uma possível onda de tolerância que lhe fosse conseguinte, (ii) a já conhecida identificação havida entre mexicanos e uso da maconha e (iii) a inserção do cânhamo no rol de substâncias passíveis de interdição anunciado pela Convenção de Genebra de $1925^{163}$ contribuíram para que logo emergissem fortes as associações entre o uso da droga e os supostamente degenerados, depravados e violentos imigrantes mexicanos ${ }^{164}$. Malgrado as investigações científicas de então já tendessem a um sentido contrário ao da propaganda estigmatizante, em 1937 viria a lume o Marihuana Tax Act, que, contendo normas penais imiscuídas em regulações administrativas, pode ser considerado, tanto do ponto de vista político quanto jurídico, uma lei análoga ao que fora o Harrison Act para opiáceos ${ }^{165}$.

A vedação ao uso e distribuição de psicoativos não era a única, mas apenas uma das formas de controle social formal exercido com o fim de estabelecer o domínio sobre grupos alheios ao wasp. De todo modo, findas as primeiras décadas do século XX, a doutrina da proibição já se incorporara, definitivamente, às estratégias de segurança pública locais.

Dada a elevação dos EUA à condição de superpotência capitalista dominante, também a sua política proibicionista não se revelaria difícil de ser exportada para os demais países, que começavam, nos anos 20, "a acolher a idéia da dieta farmacológica como incumbência estatal" ${ }^{\text {166 }}$. Assim, a Sociedade das Nações houve por criar órgãos permanentes dedicados à fiscalização do tráfico, e os países avançados, vencedores e vencidos na guerra, alheios às complexas relações sociais existentes nos EUA (sobretudo até a revogação da lei seca), acostumavam-se a legislar, sem atropelos ou interrupções, sobre esse novo campo - invariavelmente segundo determinações de uma autoridade internacional que, por sua vez, cedia às iniciativas sugeridas pela delegação estadunidense ${ }^{167}$. Os grandes laboratórios, a seu turno, contentaram-se com novas descobertas de psicofármacos tão ou mais

\footnotetext{
${ }^{163}$ Por sugestão da delegação britânica, porquanto o raxixe passara a simbolizar no Egito atitudes coloniais subversivas, por vezes solapando o mercado de psicoativos - uísque, gim, tabaco, heroína comercializados pela metrópole imperialista. Idem, ibidem, p. 701.

${ }^{164}$ Idem, ibidem, pp. 689-692.

165 Idem, ibidem, pp. 692-698.

166 Idem, ibidem, p. 681.

${ }^{167}$ Idem, ibidem, p. 681.
} 
poderosos e lucrativos que os antigos e que, ao não serem associados a grupos marginalizados ou culturas colonizáveis, perenizar-se-iam como inocentes medicamentos $^{168}$. O proibicionismo, a essa altura, já era uma política vitoriosa.

Ainda no entre-guerras, firmaram-se, na cidade de Genebra, três convenções internacionais sob os auspícios da Sociedade das Nações. A primeira, em 1925, agregou a heroína e o cânhamo ao rol de substâncias cuja tutela internacional fora instituída na Haia, seguiu os princípios desta quanto à ilegitimidade de qualquer uso não médico ou científico dos fármacos, e criou o primeiro comitê internacional permanente de fiscalização. A segunda, em 1931, tencionou executar diretrizes assentadas na anterior, estabelecendo avaliações das quantidades necessárias ao uso autorizado que cada país se obrigava a apresentar anualmente ${ }^{169}$. A terceira, em 1936, caracterizou-se pela perfeita identidade entre os critérios estadunidenses e aqueles assumidos pela autoridade internacional, obrigando os Estados-partes a perseguirem o não apenas o tráfico mas qualquer relação com estupefacientes reprimindo severamente, inclusive, a sua posse e os atos preparatórios dos delitos correspondentes $^{170}$ - e recomendando-lhes criar serviços policiais especializados ${ }^{171}$.

O proêmio da guerra fria trouxe consigo um novo tempo de caça às bruxas na América do Norte, o macarthismo, de que se aproveitou o FBN para propalar um suposto complô comunista para a exportação clandestina de opiáceos, visto que, aparentemente, grupos mafiosos russos se ocupavam do contrabando ${ }^{172}$. Nenhuma menção se fez, contudo, ao suporte americano às máfias marselhesa e chinesa - a qual se mudaria para Taiwan juntamente com o líder Chiang Kai-shek ${ }^{173}$. Nesse contexto, novos diplomas legislativos seriam aprovados: o Boggs Act, de 1951, impunha pena mínima de dois anos de prisão a réus primários que consumissem ou portassem qualquer quantidade de droga; ainda mais duro, o Narcotics Control Act, de 1956, elevava a cinco anos tal limite mínimo, podendo

\footnotetext{
${ }^{168}$ Idem, ibidem, p. 682.

${ }^{169}$ A delegação norte-americana fixara a idéia de se estabelecerem limites atinentes à produção e circulação dos fármacos de uso controlado para cada país.

${ }^{170}$ Art. 20 " $a$ " e " $d$ ".

${ }^{171}$ A respeito, vide: ESCOHOTADO, Antonio. Historia general de las drogas, $3^{\mathrm{a}}$ ed. Madrid: Espasa, 2000, pp. 699-705.

${ }^{172}$ Não há evidências concretas de que as potências comunistas - URSS e China - hajam estimulado a exportação de psicoativos como forma de subversão política, embora claramente possam ter lucrado com tal comércio. Idem, ibidem, pp. 728-729.

${ }^{173}$ Idem, ibidem, pp. 727-729.
} 
chegar até a prisão perpétua ou mesmo, no caso de um adulto que vendesse droga a um menor de 18 anos, a pena capital.

O resultado de novo recrudescimento foi uma elevação ainda maior nos preços e, portanto, na rentabilidade do negócio. As importações contrabandeadas massificaram-se, e, no varejo, a fim de desviarem-se dos rigores da lei, traficantes recrutaram menores de idade para as vendas nas ruas ${ }^{174}$. O crescimento do consumo e da dependência foi notável nos anos subseqüentes às leis Boggs e Narcotics Control. Não obstante, o perfil dos usuários também experimentava uma sensível modificação: iniciava-se a era dos junkies americanos.

Se, nos primórdios do proibicionismo, consumidores de drogas satisfaziam seu desejo ou seu vício de forma oculta e geralmente ocasional, muitas vezes visando a lidar com angústias pessoais ou cumprir com suas tarefas laborais, a partir de meados da década de 1950, ao revés, jovens usuários introjetavam a imagem erigida pelo ideário proibicionista ao consumir um bem que lhes conferia irresponsabilidade e identificação com grupos de iguais com que se relacionariam e compartilhariam hábitos e rituais de uso - no mais das vezes, intravenoso. Incorporavam uma certa rebeldia sem causa como atitude ética e estética contraposta à de heróis nacionais de seu tempo como o senador Joseph McCarthy e o czar antidrogas Harry Anslinger ${ }^{175}$, pelo que marginalizavam a si próprios e expunham publicamente seus hábitos com drogas sem maior hesitação ${ }^{176}$. Nessa medida, empreenderam um processo de mitificação do consumo de drogas em estratos sociais

\footnotetext{
${ }^{174}$ Idem, ibidem, p. 735.

${ }^{175}$ Chefe do FBN entre os anos de 1930 e 1963, Harry J. Anslinger desempenhou papel fundamental na consolidação do probicionismo dentro e fora dos Estados Unidos. À sua liderança se atribuem em grande medida as campanhas contra a maconha nos anos 30, e os resultados da terceira Convenção de Genebra, de 1936. Mais tarde, no pós-guerra, a concentração de poderes que reunira em torno de si e suas extraordinária influência política e identificação com os princípios patriótico-moralistas reinantes nos EUA fariam do $F B N$ pilar fundante da estrutura burocrática de segurança nacional desse país (McALLISTER, William B. Drug diplomacy in the twentieth century. New York: Routledge, 2000, pp. 147-148).

${ }^{176}$ A introdução e popularização do termo e da cultura junkie se deve à obra do escritor William S. Burroughs (especialmente em: Junkie. New York: Ace Books, 1953; e Naked lunch. New York: Grove Press, 1959), que, ao lado de Allan Ginsberg e Jack Kerouac, liderou o chamado "movimento beatnik" - ou "geração beat" - em meados da década, considerado o principal precursor a contracultura nos EUA. Ginsberg, inclusive, chegou a publicar artigo sobre a maconha: ("The Great marijuana boax: first manifesto to end the bringdown". In: Atlantic Monthly, Nov/1966, pp. 104 et seq.).
} 
médios americanos, que se quedaria mais evidente no decênio posterior, com a contracultura, e, ainda, que influenciaria grupos de jovens em diferentes países ${ }^{177}$.

Ao notável recrudescimento legislativo dos anos 50 e à emergência da cultura junkie - e, com ela, a mitificação do consumo de drogas - seguiu-se uma multiplicação do uso e dependência de substâncias proibidas nos EUA. Então, de fato, o consumo de drogas como a heroína e a maconha tornava-se um problema de consideráveis proporções - o que, ao contrário do que havia pretendido, no início do século, a propaganda moralista e segregacionista que lhe ensejara, não sucedia antes da escalada da proibição. A resposta, no entanto, foi apenas o óbvio: mais endurecimento nos planos executivo e legislativo, a despeito de já haver muitas contestações de sociólogos, médicos e juristas à eficácia da proibição sobre seus manifestos propósitos preventivos e repressivos ${ }^{178}$.

De outra parte, convém assinalar que as três décadas que se seguiram ao término da Segunda Grande Guerra conheceram, também a partir dos EUA, a massificação do uso de pílulas medicinais manufaturadas - como analgésicos, estimulantes, barbitúricos, tranqüilizantes e antidepressivos. Deveras, à medida que se inebriar ou se embriagar tornara-se um hábito socialmente reprovável segundo padrões culturais dominantes, e porquanto tais pílulas se apresentavam como higiênicas e científicamente aprovadas, seu consumo veio, em certa medida, preencher o espaço antes ocupado pelo consumo de álcool ${ }^{179}$. Tratava-se de uma época de crescimento econômico sustentado sem precedentes no mundo industrializado $^{180}$, em que, contudo, remanesciam ansiedades e traumas sociais decorrentes (i) da magnitude do conflito bélico que a precedera e das explosões nucleares que marcaram seu crepúsculo e (ii) de momentos de extrema tensão

\footnotetext{
${ }^{177}$ Quanto à influência do puramente alegórico no uso de drogas que então se irradiava, cabe citar dois casos exemplares referidos por Escohotado: (i) o de um músico americano de jazz que, após detido por embriaguez, seu comportamento fez crer aos médicos tratar-se de um heroinômano, levando-os a lhe administrarem doses de manutenção para prevenir prejuízos maiores; ao depois, descobriu-se que seu suposto vício não era senão uma fraude, e, no entanto, ele rogou aos médicos que não dissessem a verdade à sua esposa e sua família pois não queria perder o status de toxicômano; (ii) o do primeiro cliente dos Narcóticos Anônimos em Londres, que se apresentou como heroinômano mas que era apenas um jovem "imbecilizado pelo uso massivo de barbitúricos". ESCOHOTADO, Antonio. Historia general de las drogas, $3^{\mathrm{a}}$ ed. Madrid: Espasa, 2000, p. 739.

${ }^{178}$ Idem, ibidem, pp. 732-745.

${ }^{179}$ DAVENPORT-HINES, Richard. The pursuit of oblivion: a global history of narcotics. London New York: W. W. Norton, 2002, p. 299.

${ }^{180}$ HOBSBAWM, Eric John. Era dos extremos: o breve século XX. Trad. Marcos Santarrita. São Paulo: Cia. das Letras, 1995, pp. 253 et seq.
} 
política entre os protagonistas da guerra fria ${ }^{181}$. Ademais, a cultura individualista predominante no mundo ocidental em muitos casos "degenerava em angústia existencial, egoísmo e auto-destruição" ${ }^{\prime 182}$. Tudo isso levou à emergência de uma nova realidade, em que o uso por milhões de pessoas de drogas industrializadas se revelava irracional ${ }^{183}$, freqüentemente mais nocivo que o de substâncias proscritas, mas não era devidamente observado pelas instâncias executivas oficiais ${ }^{184}$. Assim,

enquanto que o uso recreativo de drogas por jovens eralhes, em geral, uma fase experimental transitória [mas que lhes estigmatizava e estereotipava], mulheres donas-decasa estimuladas por anfetaminas e executivos sedados por 'miltown' eram longevos usuários habituais que repudiavam a idéia de que possuíssem problemas com $\operatorname{drogas}^{185}$.

Estas permaneceriam, de fato, as condições farmacológicas em que vivia a sociedade norte-americana ao tempo em que, poucos anos mais tarde, o país lançar-se-ia decididamente à caça aos cultivos de cannabis, coca e papoula em todo o mundo. Nada disso, ademais, constituiria qualquer embaraço a que, simultaneamente, o país fomentasse vigorosamente as suas exportações de álcool, tabaco, tranqüilizantes e estimulantes sintéticos; assim, onde houvesse cultura de uso de psicoativos naturais, impor-se-ia, pela propaganda ou pela força, sua substituição

${ }^{181}$ DAVENPORT-HINES, Richard. Op. cit., pp. 301-302.

${ }^{182}$ Idem, ibidem, p. 302.

${ }^{183}$ Números que apontam o crescimento do consumo de fármacos industrializados desde a metade do século realmente impressionam: ilustrativamente, cite-se que, em grande medida estimulado por maciços investimentos em propaganda, o consumo de analgésicos leves - como, v. g., aspirina dobrou nos Estados Unidos entre 1940 e 1948, assim como na Dinamarca entre 1951 e 1957 e na Austrália entre 1955 e 1961. Na Inglaterra, 25\% das mulheres com mais de quarenta anos eram dependentes do uso diário de barbitúricos. O mercado de anfetaminas e tranqüilizantes também experimentou crescimento exponencial no mesmo período. (Idem, Ibidem, p. 303-305; ESCOHOTADO, Antonio. Historia general de las drogas, $3^{\mathrm{a}}$ ed. Madrid: Espasa, 2000, p. 885). Assim é que, em 1960, o consumo de drogas estimulantes (excluindo-se a cafeína) manufaturadas nos EUA chegava a quinhentas toneladas anuais, o que equivalia a aproximadamente quatro toneladas de cocaína - cerca de trinta vezes mais que o consumo de 1910; a seu turno, o consumo de drogas narcóticas ali chegava a duas mil toneladas, cuja atividade poderia equivaler a algo entre vinte e cinquienta mil toneladas de ópio - o que significava uma atividade entre três e sete vezes a cifra máxima consumida pela sociedade chinesa, em fins do século XIX. Surgira, destarte, a "sociedade adicta”. ESCOHOTADO, Antonio. Op. cit., pp. 786-787; 885.

184 Assinala-se que, de certo modo, a difusão dessas drogas se deveu a agentes terapêuticos - e instituições oficiais - que viam nelas uma reserva das sociedades avançadas que se contrapunha aos derivados do cânhamo, da coca, da papoula e da dormideira, cujo uso se associara a rituais de tempos e nações remotas. Substituíam-se, pois, uns por outros fármacos, mas não a ansiedade do homem contemporâneo; e, assim, "o que as pessoas fizeram foi confiar nos governos, e o que os governos fizeram foi substituir uma farmacopéia por outra, seguindo a tendência de preferir o sintético ao natural, o patenteado ao não patenteado, o manufaturado ao que germina espontaneamente e pode ser usado mediante transformações mínimas". ESCOHOTADO, Antonio. Ibidem, pp. 785-786. Trad. livre.

${ }^{185}$ DAVENPORT-HINES, Richard. Op. cit., p. 300. 
por sucedâneos industrializados ${ }^{186}$. E somente nas últimas décadas do século $\mathrm{XX}$ as chamadas drogas sintéticas viriam a se tornar objeto de maior preocupação de formuladores de políticas públicas atinentes às drogas.

A intensificação, nos países centrais, desde fins dos anos 50, de apresentações de estudos e relatórios científicos elaborados por médicos, sociólogos e juristas apontando a contraproducência da proibição perante seus fins manifestos levou a que, já no início da década subseqüente, houvesse importante alteração na maneira de se tratar a questão do usuário. Este, até então visto como um degenerado social, inexorável criminoso, passou a ser compreendido essencialmente como um doente, que, portanto, deveria ser tutelado antes por médicos que pelas agências de controle do crime. Isso significou, de certo modo, um restabelecimento de prerrogativas médicas desprezadas na escalada proibicionista da primeira metade do século. Significou, também, no âmbito da política interna norte-americana, uma concessão do $F B N$, que abria mão de seu monopólio para gerenciar o problema a fim de evitar maiores oposições ao seu modelo proibicionista, e deixava de perseguir médicos e farmacêuticos. Mas, sobretudo, significou uma mudança apenas limitada de abordagem do problema que, ao garantir a ingerência oficial sobre a esfera privada de liberdade do indivíduo, justificava a plena manutenção do viés coercitivo.

Isso porque a novel concepção terapêutica da questão do consumo de drogas impunha tratamentos a todos e quaisquer usuários, sem considerar seu eventual desejo ou aquiescência a eles. Pressupunha que, como indivíduos doentes, não possuíam condições psíquicas para se autotutelarem livremente, o que justificaria a intervenção compulsória sob alegadas razões altruísticas - a ideologia do tratamento $^{187}$.

Sob influência dessa mudança na abordagem da questão do uso de psicoativos, e mais uma vez tendo a diplomacia norte-americana como principal

\footnotetext{
186 “[...] Também por esses anos o Ministério da Agricultura americano se lança a fomentar o consumo de tabaco no estrangeiro, subvencionando generosamente os estúdios de Hollywood para que roteiristas inserissem cenas capazes de estimular o hábito. Em 1964, centenas de toneladas que provêm de excedentes da costa tabaqueira do ano anterior se incluem como aporte americano do programa internacional Comida para a Paz. Já havia décadas que os principais destiladores americanos também subvencionavam Hollywood para que houvesse em todas as cenas possiveis alguém oferecendo uma taça de licor, sinal de modernidade e distinção quando se dispunha do apropriado mobiliário". ESCOHOTADO, Antonio. Op. cit.., p. 788.

187 Idem, ibidem, pp. 744-758.
} 
protagonista, firmar-se-ia, em 1961, a Convenção Única das Nações Unidas sobre Entorpecentes, ampliando-se as deliberações multilaterais em favor da proibição, mas aceitando a abordagem médica do tratamento do usuário. Já em seu preâmbulo, explicitava-se a ideologia da norma internacional:

\begin{abstract}
As partes, preocupadas com a saúde física e moral da humanidade, $[\ldots]$ reconhecendo que a toxicomania é um grave mal para o indivíduo e constitui um perigo social e econômico para a humanidade, conscientes de seu dever de prevenir e combater êsse mal $[\ldots]^{188}$.
\end{abstract}

Destarte, além de manter-se a anacrônica noção de "saúde moral", sugeria-se a ampliação do valor pretensamente tutelado pelas normas proibitivas, abarcando também a ordem econômica, além da saúde individual e pública e da tranqüilidade social.

Também em seu preâmbulo, reconhecia-se ser "o uso médico [...] indispensável para o alívio da dor e do sofrimento" "189, e que deviam tomar-se "medidas adequadas [...] para garantir a disponibilidade de entorpecentes para tais fins" 190 , limitando-se, no entanto, "o uso dessas substâncias a fins médicos e científicos" ${ }^{\prime 191}$. Quanto ao consumo em si, a versão original em inglês ${ }^{192}$ diferenciava claramente os conceitos de uso e abuso, mediante o critério arbitrário da mera autorização legal - pelo que o consumo lúdico isolado, mesmo que em quantidade insignificante, já constituía abuso, ao passo que uma overdose mediante prescrição médica poderia não o ser. Inaugurava, ademais, o sistema de listas de substâncias controladas: a lista I albergava ópio, morfina, cocaína, metadona e outras oitenta substâncias, assimiladas a opiáceos, mesmo que fossem sintéticas; a lista II continha codeína e outras oito, que contemplava um controle menos severo que a anterior; a lista III, de drogas de fiscalização mais branda, abrangia composições com substâncias da lista anterior ou com ópio, cocaína ou morfina até uma determinada proporção; e a lista IV, cujos integrantes mereceram um controle extremo justificado

\footnotetext{
188 Tradução oficial para o português, conforme a internalização da convenção no direito brasileiro Decreto 54.216/64. Disponível em: <http://www.unodc.org/pdf/brazil/Convencao\%20Unica\%20de\%201961\%20portugues.pdf $>$. Acesso em: 10/01/2009.

${ }^{189}$ Ibidem. Acesso em: 10/01/2009.

${ }^{190}$ Ibidem. Acesso em: 10/01/2009.

${ }^{191}$ Ibidem. Acesso em: 10/01/2009.

${ }^{192}$ Disponível em: <http://www.unodc.org/pdf/convention_1961_en.pdf>. Acesso em: 10/01/2009.
} 
por alegadas propriedades super-viciadoras, em que figuravam a heroína, a cannabis e sua resina e dois outros opiáceos ${ }^{193}$.

Tal documento de 1961, por admitir o uso médico - ainda que somente se sob intenso controle -, apresentou-se como progressista. Em verdade, malgrado toda a campanha ideológica iniciada muitas décadas antes, somente os EUA, com os junkies, tinham maiores problemas com drogas ilícitas naquele tempo ${ }^{194}$. Compatibilizava-se a convenção, ademais, com os princípios paternalistas próprios do modelo de welfare state então reinante especialmente na Europa. Não obstante, a ausência de suas listas de muitas drogas sintéticas de efeitos similares ou mais perniciosos que aquelas ali incluídas, porém, deixaria claro até que ponto critérios que supostamente visavam à proteção da saúde humana eram de natureza farmacológica ou deixavam de sê-lo ${ }^{195}$.

Outrossim, ainda em fins dos anos 50, substâncias psiquedélicas interessaram laboratórios e agências oficiais: aqueles buscavam, sem êxito, uma nova panacéia farmacológica - razão por que haviam pressionado para que tais drogas não fossem incluídas em qualquer das listas da Convenção Única de $1961^{196}$-, visto que a $C I A^{197}$ e o exército estadunidense pretendiam obter algo capaz de manipular ou neutralizar a mente de inimigos. Para isto, realizaram testes secretos a que dezenas de milhares de pessoas foram inconscientemente submetidas ${ }^{198}$; verificada a inaptidão do fármaco para as pretensões oficiais, interromperam-se os testes em $1959^{199}$.

\footnotetext{
${ }^{193}$ Art. 2. As listas internacionais atualizadas de substâncias controladas encontram-se disponíveis em: $<$ http://www.incb.org/pdf/yellow_lists_all/47th_edition_dec_07_yellow-list_eng.pdf >. Acesso em: $10 / 02 / 2009$.

${ }^{194}$ ESCOHOTADO, Antonio. Historia general de las drogas, $3^{\text {a }}$ ed. Madrid: Espasa, 2000, pp. 756757.

${ }^{195}$ Idem, ibidem, pp. 757 et seq. Lembra o autor que as drogas lícitas - que seguiam propagandeadas como panacéias por grandes laboratórios, e vendidas aos milhões (com ou sem prescrição médica) foram difundidas como substâncias seguras, infinitamente superiores àquelas provenientes do mundo subdesenvolvido, e, ilustrativamente, que chegaram a ser oferecidas até pela missão diplomática norte-americana na Índia às classes médias e altas deste país, sugerindo-lhes substituir, assim, o uso de opiáceos naturais e da cannabis (p. 780). Lembra também que tranqüilizantes neurolépticos, demais de seu alto índice potencial de causação de dependência, são, isoladamente, responsáveis por um número de mortes por overdose acidental nos EUA superior às mortes causadas por overdose (e não por adulteração) de todas as drogas ilícitas somadas (p. 782).

${ }^{196}$ RODRIGUES, Thiago. Política e drogas nas Américas. São Paulo: Educ - Fapesp, 2004, p. 76.

${ }^{197}$ Central Intelligence Agency, instituída em 1947.

${ }^{198}$ ESCOHOTADO, Antonio. Op. cit., pp. 807-812.

${ }^{199}$ Idem, ibidem, p. 811; RODRIGUES, Thiago. Op. cit., p. 76.
} 
Contudo, a partir de análises experimentais de uma elite intelectual ${ }^{200}$, disseminar-seia o uso de drogas visionárias durante a década de 1960 entre os movimentos artísticos, contestatórios e de desobediência civil a cuja reunião se convencionou chamar de contracultura ${ }^{201}$. Em face da variedade de novos psicoativos disponíveis, a resposta da burocracia oficial, previsivelmente, foi a criação de novas agências de controle e a gradual estigmatização e proscrição dessas substâncias que já não mais se lhe revelavam interessantes ${ }^{202}$; chegou-se a afirmar, em 1966, que drogas psiquedélicas constituíam "a maior ameaça que se impunha ao país; [...] mais perigosa que a guerra do Vietnã ${ }^{203}$.

Grupos e comunidades que cultivavam a psiquedelia, ademais, coincidiram em postular a despenalização do consumo da cannabis, que, de substância de uso infreqüente e peculiar a imigrantes pobres, logo se tornou o "fármaco favorito de classes média ilustradas e universitários" ${ }^{204}$. Em verdade, nos anos 60, já havia um razoável consenso no plano médico-científico quanto à imprestabilidade da cruzada ao uso de drogas ante seus manifestos fins $\operatorname{preventivos}^{205}$, e, agora, dada a posição econômico-social de seus novos consumidores, a abordagem segregacionista que até então a maconha merecera

200 ESCOHOTADO, Antonio. Op. cit., pp. 792-806. Entre os estudiosos pioneiros das drogas ampliadoras da consciência encontram-se, por exemplo, o escritor britânico Aldous Huxley, o psicólogo harvardiano Timothy Leary e o notável químico suíço Albert Hofmann - este, responsável pela sintetização do ácido lisérgico $(L S D)$.

${ }^{201}$ ESCOHOTADO, Antonio. Op. cit., pp. 792-806; 836-858.

${ }^{202}$ RODRIGUES, Thiago. Op. cit., pp. 78-79; ESCOHOTADO, Antonio. Op. cit., pp. 811; 864-879. Entre outras consequiências, assinala este autor que da proscrição resultou um derrame no mercado negro de substâncias altamente impuras e tóxicas, ao passo que, até então, o $L S D$ era um produto barato cujo desenvolvimento mantinha-se, sobretudo, em poder de escrupulosos cientistas e de seus seguidores nas principais universidades. Porém, mais que o uso em si, no caso do $L S D$ a preocupação oficial repousava nas investigações científicas mesmas que sua cultura trazia em seu bojo, e que, se não podiam ser devidamente controladas pelo governo, haviam que ser prevenidas - razão por que, da noite para o dia, de notável avanço psicofarmacológico o LSD seria convertido em substância diabólica por força de mero ato legislativo (pp. 864-866).

${ }^{203}$ McGLOTHLIN, William H. "Toward a rational view of hallucinogenic drugs". In: Journal of psychedelic drugs, vol. I, issue I. San Francisco: Haight-Ashbury, summer/1967, p. 99. Na esteira das manipulações de opinião pública operadas pelos empresários morais e pelo mass media, vale anotar que o autor dessa grave assertiva, Charles W. Sandiman, era um senador estadual em New Jersey que, no ano anterior, fora derrotado em sua candidatura ao Congresso. Após sua campanha à frente de uma comissão estadual de estudos sobre drogas, saiu vencedor da eleição subseqüiente para o Congresso (1967), e garantiu sua conseguinte indicação para candidatar-se a governador do estado pelo Partido Republicano. BUNCE, Richard. "Social and political sources of drug effects: the case of bad trips on psychedelics". In ZINBERG, Norman E.; HARDING, Wayne M. (eds.). Control over intoxicant use: pharmacological, psychological and social considerations. New York: Human Sciences Press, 1982, p. 119.

${ }^{204}$ ESCOHOTADO, Antonio. Op. cit., p. 858-859.

205 SKOLNICK, Jerome H. Coertion to virtue: the enforcement of morals, p. 260. Apud ESCOHOTADO, Antonio. Op. cit., p. 792. 
tenderia, ainda que de modo limitado, a se modificar perante a sociedade americana. Reforçava-se então a idéia de que, antes da sanção penal, ao usuário cabia o tratamento compulsório; a ideologia da repressão, destarte, apenas renovava-se e consolidava a apresentação de uma nova face, que, se de um lado continuaria a impor sanções aos usuários, de outro prestava-se muito bem a justificar a perenização e a intensificação da cruzada através da tese de produtores opressores e de consumidores oprimidos.

Superados os tempos de contestações políticas e efervescência cultural que caracterizaram os anos 60, o encerro da década conheceu um marcante recrudescimento da política criminal norte-americana como um todo, representado pela emergência definitiva do discurso de lei e ordem (law and order) na vitoriosa campanha eleitoral de Richard Nixon. Empossado o novo presidente em janeiro de 1969, passaram-se a implementar medidas de combate à criminalidade que visavam a comunicar ao eleitorado uma sensação de incremento na eficácia do aparato repressivo oficial. Foi nesse contexto que logo se identificaram as drogas como um tema de particular apelo político-ideológico e propagandístico, o que determinaria o tratamento a ser por elas merecido a partir de então ${ }^{206}$.

\subsubsection{Anos 70: repressão de drogas como assunto de segurança nacional, e posterior exportação da guerra às drogas sob a forma de intervencionismo militarista}

\footnotetext{
${ }^{206}$ Anota Baum que, vencidas as eleições com o uso de propaganda fortemente baseada no discurso de lei e ordem, impunha-se à - inexperiente - equipe que assumiria a Casa Branca a dificuldade de cumprir o que alardeara, na medida em que a competência executiva e legislativa acerca de prevenção e repressão da criminalidade urbana - ou seja, daqueles crimes que suscitam maior sensação de insegurança social - era eminentemente estadual e a matéria era vista pela população como assunto de natureza local. Havia-se que estabelecer, então, um campo de atuação federal nas políticas de policiamento de ruas, tendo-se chegado a cogitar a federalização dos crimes de roubo e furto a residências - algo que, entretanto, à evidência não teria qualquer base legal e constitucional. Sugeriuse, então, o envolvimento nas políticas de repressão ao comércio e uso de drogas, porquanto a produção e a circulação de tais substâncias claramente implicavam questões de controle de fronteiras nacionais e interestaduais, permitindo, assim, intervenção federal na matéria com vistas a responder as expectativas criadas durante a campanha eleitoral (BAUM, Dan. Smoke and mirrors: the war on drugs and the politics of failure. Boston: Back Bay Books, 1997, p. 13-17; 28). Assim, dado o potencial propagandístico de uma intensificação da cruzada contra as drogas, pouco importava que o número de americanos mortos em virtude do uso de drogas ilícitas no país em 1969 houvesse sido inferior, por exemplo, ao de mortos engasgados com alimentos ou acidentados em escadarias (ibidem, p. 28).
} 
Ante o término da guerra no Vietnã em meados de 1971, afirmou Nixon, em pronunciamento ao Congresso, que os Estados Unidos estavam diante de uma "emergência nacional", tendo as drogas tornado-se o "inimigo número um" da nação, pelo que se impunha um plano de ataque sem precedentes na história ${ }^{207}$. Era necessário declarar-lhes guerra e, assim, nas semanas subseqüentes, surgiria a expressão war on drugs para referir-se ao combate ao mercado de psicoativos dentro dos EUA bem como sua produção e circulação em toda e qualquer parte do mundo. Para o presidente, de fato, a intransigente caçada às drogas era uma questão crucial para a moralidade norte-americana, assim como o era também para as suas pretensões de reeleição ${ }^{208}$.

As medidas anunciadas por Nixon em junho daquele ano implicavam imediatos investimentos de centenas de milhões de dólares e compreendiam o financiamento de pesquisas para produção de herbicidas, o desenvolvimento de novos mecanismos de detecção de drogas, maior controle alfandegário, a busca pela responsabilização criminal de traficantes dentro e fora do país e o tratamento compulsório a usuários $^{209}$. O plano governamental incluía, ainda, a futura criação de um órgão que centralizasse a coordenação das políticas de controle sobre psicoativos, então dispersas entre nove agências federais, e que deveria abarcar também ações militares $^{210}$.

Efetivamente, em linhas gerais, tais medidas comporiam o cerne da política do war on drugs que teria prossecução nas décadas seguintes, a qual ainda justificaria numerosas ações de ingerência na política interna de outros países. Dessa maneira, os EUA, que por razões diversas tornaram-se o principal mercado consumidor de psicoativos, consagravam o discurso da existência de países produtores e países consumidores, passando a se apresentar como vítimas de uma suposta invasão externa. Referiam-se a grupos clandestinos que alegadamente estariam a atentar contra a sua soberania, infringindo as suas leis e trazendo-lhes problemas crônicos de segurança e saúde públicas. Justificar-se-iam, pois, aos olhos

207 “THE NEW PUBLIC ENEMY No 1". Time Magazine, 28/06/1971. Disponível em: <http://www.time.com/time/magazine/article/0,9171,905238-1,00.html. Acesso em: 10/01/2009>.

${ }^{208}$ Ibidem. Acesso em: 10/01/2009. A alvorada da guerra às drogas contou com expressivo apoio do mass media, que se refletiria nas pesquisas de opinião pública.

${ }^{209}$ Ibidem. Acesso em: 10/01/2009.

${ }^{210}$ Ibidem. Acesso em: 10/01/2009. 
estadunidenses ações externas de combate, a partir do que se passou a tratar do tema como política de segurança nacional, mobilizando-se todo um aparato militar.

No plano internacional seria firmado em Viena, no ano de 1971, a Convenção sobre Substâncias Psicotrópicas, que não possuiu qualquer pretensão de suplantar a Convenção Única de 1961, mas de somar-se a ela. Tratou-se, em verdade, de mais uma reunião estimulada pela diplomacia estadunidense, ora na pretensão de proscrever internacionalmente também as drogas ampliadoras da consciência legitimando a sua opção político-jurídica interna -, e de manifestar alguma regulação - ainda que simbólica - sobre os fármacos lícitos que tanto abuso ensejavam já havia décadas.

Como ocorrera dez anos antes, o preâmbulo do documento acordado referia-se à proteção da saúde física e mental da humanidade e à preocupação com que não se restringissem indevidamente para uso médico e científico as substâncias ali abrangidas ${ }^{211}$. Estabeleceram-se, então, novas listas de substâncias: a lista I compreendeu todas as utilizadas pelos adeptos da contracultura, entre elas o $L S D$, a psilocina, a mescalina e o $\mathrm{THC}^{212}$; a lista II, as anfetaminas e seus derivados e a fenclicidina; a lista III, alguns barbitúricos e a glutetimida; a lista IV, outros barbitúricos, o meprobamato e alguns hipnóticos não barbitúricos. As drogas que compuseram a primeira lista eram, em regra, e de longe, as de menor toxicidade (proporção entre dose ativa e dose letal), bem como não criavam dependência ou tolerância como as outras. Porém, o controle que se lhes impôs foi marcadamente ilógico: ao passo que, acerca das listas II, III e IV, prescreveu-se que cada uma das partes limitaria a fins médicos e científicos, "por meio das medidas que considerar apropriadas, a fabricação, a exportação, a importação, a distribuição, o comércio, o uso e a posse" ${ }^{213}$ dessas substâncias, a lista I mereceu expressa vedação a "todo uso, exceto para fins científicos e para fins médicos muito limitados, por pessoa devidamente autorizada em estabelecimentos médicos e científicos que estejam

\footnotetext{
${ }^{211}$ Versão oficial traduzida para o português (decreto $\mathrm{n}^{\circ}$ 79.388/77) disponível [on-line] em: http://www2.mre.gov.br/dai/psicotr\%C3\%B3picas.htm. Acesso em: 10/01/2009.

${ }^{212}$ Arrola-se aqui o princípio ativo da cannabis - o THC -, erroneamente incluída na lista de narcóticos em 1961, de regime excepcionalmente gravoso. Ao manterem-se como estavam as listas anteriores, contudo, não se reparou o erro anterior, que se dera de forma idêntica igualmente com a cocaína.

${ }^{213}$ Art. $5^{\circ}, 2$.
} 
diretamente sob controle de seus governos" ${ }^{214}$. Assim sendo, mantinha-se um estatuto liberal para substâncias cuja produção era controlada por grandes laboratórios, e que no mais das vezes "não eram senão sucedâneos melhores ou piores da cocaína e de opiáceos" ${ }^{215}$, e condenava-se ao obscurantismo outras muito menos perigosas à saúde humana e que ainda se revelavam cientificamente promissoras, mas que eram vistas como drogas subversivas ${ }^{216}$.

Cabe anotar que, um ano depois, novamente reunidas as autoridades governamentais em Genebra, estabeleciam-se algumas modificações no texto da convenção de 1961 através da assinatura do Protocolo Adicional à Convenção Única, que, entretanto, manteve intacta a essência do documento original.

Em 1973, o Congresso estadunidense autorizou a criação da Drug Enforcement Administration (DEA $)^{217}$, cujo escopo fundamental era garantir em todos os cantos do país a aplicação das severas políticas e normas federais de repressão às drogas, para o que recrutaria agentes da CIA para cargos diretivos e empregaria métodos típicos de serviço secreto. Além de questões de política interna, incluíram-se entre as suas atribuições incumbências externas, notadamente a coordenação de ações de força e de inteligência, como o apoio a pesquisas e treinamentos de agentes de repressão tanto dentro quanto fora do país.

Deveras, era o momento da definitiva exportação do war on drugs por todo o mundo - desenvolvido e subdesenvolvido. Por ocasião da aprovação da Convenção Única, dada a resistência de países periféricos para com a idéia de imediato banimento do cultivo e do consumo de algumas substâncias que faziam

\footnotetext{
${ }^{214}$ Art. $7^{\circ}$, " $a$ ". Note-se que, não obstante, eventuais cientistas que ousassem solicitar a respectiva licença às autoridades competentes para estudar tais drogas deparar-se-iam com um problema anterior, haja vista que nenhum laboratório estabelecido legalmente se atreveria a suportar os complexos e caros procedimentos para sintetizá-las se, ao cabo, a concessão de seu registro fosse incerta - o mesmo valendo para os estabelecimentos onde poderiam ter lugar tais experiências. Mas, enfim, este era o propósito da diplomacia norte-americana: a prevenção da ciência sobre as drogas ampliadoras da consciência, não importasse o avanço médico-farmacológico que pudesse representar. A respeito, ESCOHOTADO. Antonio. Historia general de las drogas, $3^{\mathrm{a}}$ ed. Madrid: Espasa, 2000, pp. 890-892. ${ }_{215}^{21}$ Idem, ibidem, p. 890.

${ }^{216}$ Idem, ibidem, p; 892. Efetivamente, a circunstância de o consumo de drogas visionárias haver sido próprio de grupos contestadores das instituições vigentes também explica a reação desproporcional por elas sofrida.

${ }^{217}$ Note-se que o vocábulo "enforcement" tem aqui um significado de "aplicação da lei" ou execução do direito, podendo também denotar "coerção" ou "coação". A DEA nasceu sob a denominação Drug Enforcement Agency, substituída apenas alguns meses após, ao momento em que também se ampliavam seus poderes e atribuições.
} 
parte de sua herança cultural secular, estipularam-se prazos para a definitiva supressão dos estupefacientes em todas as nações ${ }^{218}$. Nesse contexto, a América Latina passaria a ocupar papel de destaque entre as preocupações dos próceres do proibicionismo, em virtude dos cultivos de ópio e cannabis no México e da coca nos países andinos, onde era a relevante fonte de riqueza e parte importante componente da cultura alimentar. $\mathrm{O}$ fato de a folha de coca ali ser mascada como sucedâneo alimentar de grandes faixas populacionais impossibilitadas de consumir alimentos mais nobres ou consumida em chás inofensivos não impediria, porém, que, a partir de 1971, os EUA destinassem subsídios anuais da ordem de dezenas de milhões de dólares para que os governos locais arrasassem safras e encarcerassem pequenos comerciantes do produto, sem que nenhum centavo fosse investido para melhorar a vida de indígenas cocaleiros ${ }^{219}$.

Não obstante, a década de 1970 foi marcada em seu todo pelo exponencial crescimento do consumo de heroína, maconha e cocaína, sobremodo nas sociedades economicamente avançadas. Isso, em grande medida, pode ser atribuído ao combate e à redução do interesse por drogas alucinógenas (no caso da maconha), somados à menor disponibilidade de algumas anfetaminas (no caso da heroína e da cocaína); aos poucos, criam-se novos e rentáveis mercados para essas drogas, especialmente - uma vez mais - nos EUA ${ }^{220}$.

Especificamente acerca da maconha, pesquisas apontavam que dezenas de milhões de norte-americanos fumavam-na ocasionalmente ou haviam fumado, assim como outros milhões de europeus. Nessa medida, conquanto e ao mesmo tempo que matérias jornalísticas exaltando seu suposto caráter criminógeno

\footnotetext{
${ }^{218}$ ESCOHOTADO, Antonio. Op. cit., pp. 915 et seq.

${ }^{219}$ Idem, ibidem, pp. 922-928.

${ }^{220}$ Idem, ibidem, pp. 971-972. O autor menciona ainda que, quanto à cocaína, sua produção mundial até 1975 chegava a ser dez vezes menor que vinte anos antes; porém, a imposição de controles sobre as vendas de anfetaminas e a concentração da atenção do aparato repressor sobre as drogas visionárias desde fins da década anterior criaram condições para que se iniciasse um crescimento sustentado da importação daquela droga desde diferentes pontos da América do Sul. Em uma época em que o mercado americano era altamente receptivo a alternativas psicoativas, quantidades da droga eram ali introduzidas por viajantes particulares interessados na rentabilidade de sua venda no mercado ilegal; de outra parte, imigrantes cubanos anti-castristas conectados com grandes produtores bolivianos, colombianos e peruanos criaram uma poderosa rede de contrabando e distribuição da droga em grandes cidades da costa leste, dali expandindo-se para o oeste. A atuação destes era facilitada pelo fato de, em virtude de seu status político - entre eles havia, inclusive, ex-assistentes de Fulgencio Batista exilados -, terem contado muitas vezes com o beneplácito da CIA a prevenir maiores investigações e responsabilizações (pp. 984-986).
} 
se multiplicavam (especialmente nos EUA), chegou a haver uma tendência a que se despenalizasse o consumo e a posse da marijuana, apoiada em novos estudos científicos que demonstravam a relativa inocuidade da substância ${ }^{221}$. Assim é que, a partir de meados dos anos 70, porque ela passara a ser vista como uma droga leve e imerecedora de proibição, operou-se um movimento de despenalização - formal ou informal - em países como Holanda, Dinamarca, Canadá, Espanha, e até mesmo os EUA (tribunais da Califórnia deixaram de impor privação de liberdade a usuários em 1976; ademais, o cultivo da cannabis era freqüente em muitos estados do país) ${ }^{222}$. Cabe anotar que a tolerância ao uso da cannabis não implicou, nessas localidades, qualquer situação de emergência de saúde ou segurança públicas; ao revés, constatou-se, com o passar do tempo, progressiva redução no interesse pela droga ${ }^{223}$.

$\mathrm{Na}$ superpotência norte-americana, porém, os tempos de relativa liberalização das administrações Ford e Carter logo dariam lugar a outros que, se de um lado foram marcados pela quase absoluta desregulamentação econômica, de outro caracterizaram-se pelo forte intervencionismo na seara política: a era ReaganBush, dominada pelo fundamentalismo conservador. A política de drogas voltaria a ser pautada, então, por grupos proibicionistas, por vezes baseados em pesquisas de questionáveis metodologia e conclusões, e invariavelmente articulados em fortes campanhas mediáticas ${ }^{224}$; a seu turno, também a Suprema Corte mostrava sinais de recrudescimento em matéria de drogas ${ }^{225}$.

\footnotetext{
${ }^{221}$ Idem, ibidem, pp. 972-978.

${ }^{222}$ Idem, ibidem, pp. 975-980. É de se notar que a defesa da despenalização ou descriminalização da maconha, ora, não se subsidiava na oposição político-liberal à ingerência do Estado sobre a intimidade do cidadão, como sucedera ao final da década anterior, mas ao mero entendimento de que se tratava de uma droga mais leve que as demais, inclusive que o álcool, logo não merecia as restrições que se lhe impunham.

${ }^{223}$ Idem, ibidem, p. 980. A respeito, Escohotado traça um paralelo com a liberalização de publicações eróticas quando da redemocratização espanhola, que, se nos anos iniciais resultou em uma explosão de vendas de revistas como Playboy ou Penthouse, em seguida foi perdendo força de maneira consistente até que se verificasse, após cinco anos, um público substancialmente menor que antes; igualmente, segundo o autor, acontecera com a maconha e o haxixe após sua liberalização, porquanto se lhes subtraía o conteúdo heróico ou herético e seu valor cerimonial, convertendo-se em substâncias de importância menor.

${ }^{224}$ Idem, ibidem, pp. 981 et seq.

${ }^{225}$ The New York Times, 13/01/1982. "Supreme Court roundup: 40-year drug term held 'legislative prerogative"," Disponível

em: $<$ http://query.nytimes.com/gst/fullpage.html?sec=health\&res=9A00E1D71038F931A25752C0A9649 48260\&scp=1\&sq=supreme\%20court\%20roundup:\%2040-year\%20term\%20held\&st=cse>. Acesso em: 10/01/2009. Como seu título denota, a decisão da Suprema Corte sustentava que a duração de pena era "puramente matéria de prerrogativa legislativa", com o que justificava a manutenção de
} 
$\mathrm{Na}$ virada dos anos 80 , a cocaína já penetrara com sucesso na cultura da sociedade americana, em grande medida por haver ressurgido em meio a elites econômicas, e a transição da juventude local do radicalismo para o consumismo propiciara-lhe ainda maior aceitação social. Tratava-se da assimilação e morte definitiva da contracultura, porquanto o uso de uma substância ilícita determinada não mais significava uma esperançosa contestação aos padrões políticos e culturais então vigentes, mas um ideal yuppie de sucesso dentro das regras estabelecidas, obtido por muitos e perseguido por outros tantos. Não mais se pretendia igualar-se ao artista ou ao acadêmico contestador, mas a políticos poderosos ou a negociadores das bolsas de valores e operadores do mercado financeiro; destarte, "se a maconha oи o LSD haviam sido e ainda eram consumidos por gente desconforme com as pautas do consumo de massas, a cocaína constituiu, desde seu renascimento, um puro consumo de massas" ${ }^{226}$.

Assim sendo, a despeito de problemas crônicos de intoxicação pelo uso de maconha e cocaína ainda serem estatisticamente irrelevantes, e a despeito de ambas possuírem fiéis adeptos nas casas do Congresso e mesmo na Casa Branca, logo se levantaram as vozes dos empresários morais em busca de mais rigor policial e mais severidade penal pra os agentes provedores de tal "virtude privada e vício público" ${ }^{227}$. Ao novamente endurecer suas ações repressivas, a DEA utilizava-se, a pretexto de informar a população, de "clichês alarmistas, habitualmente contraproducentes na juventude e em boa parte dos receptores" ${ }^{228}$. De outra parte, perseguia cientistas e laboratórios que, entre outras coisas, publicavam pesquisas sobre a queda na pureza da cocaína disponível no mercado e informavam sobre compostos que lhe eram adicionados - fazendo, assim, com que traficantes menos inescrupulosos evitassem a adição de substâncias muitas vezes mais venenosas.

sentença de 40 anos de prisão para um acusado de posse e distribuição de cerca de $250 \mathrm{~g}$ de maconha no estado da Virgínia (caso Hutto v. Davis).

${ }^{226}$ Idem, ibidem, pp. 987-988. Trad. livre. Menciona o autor que, de acordo com o National Survey on Drug Abuse, em 1979 cerca de 32\% da população adulta do país - algo próximo a 45 milhões de pessoas - seriam usuários ocasionais de cocaína, e outros 10\%, usuários mais assíduos; dentre os adolescentes, a penetração já era próxima de 6\% (p. 989).

${ }^{227}$ Idem, ibidem, pp. 988-992. Igualmente não faltaram, à semelhança de um lamentável pretérito, episódios em que agentes da repressão transformaram respeitáveis médicos em (reputados) odiosos traficantes. No que concerne a intoxicações, cabe anotar que sempre foram raras no caso da cocaína, e praticamente nulas no caso da maconha; aquela somente viria a ensejar maiores problemas de saúde pública quando se viria a difundir sua versão para classes pobres - o crack.

${ }^{228}$ Idem, ibidem, p. 993. 
Atribui-se a procedimentos peculiares como esse não só os problemas decorrentes da redução na pureza da cocaína comercializada no país, mas a posterior disseminação de compostos muito mais impuros e nocivos como a pasta base e o crack, que logo a superariam em importações ${ }^{229}$.

Tampouco alcançavam os resultados pretendidos as ações externas de combate à produção das drogas que inundavam o mercado estadunidense. Revelaram-se inúteis as calamidades ambientais e humanas que visavam a erradicar plantações de coca nos países andinos; reversamente, a cada ano aumentavam as áreas cultivadas que, em meados da década, compreendiam desde a Venezuela e o Equador até o Paraguai e o Chile, e ataques militares subitâneos a enclaves camponeses pouco faziam senão incitar sentimentos revanchistas em sulamericanos $^{230}$. A economia de países como a Bolívia, a Colômbia e o Peru era dependente da cultura da coca - da produção da planta e, a essa altura, também do alcalóide -, e o proibicionismo ali não vinha a ser uma escolha voluntária, mas produto de chantagens políticas. Tinham em comum aparatos policiais e militares precários e, sobretudo, corruptos, que muitas vezes promoviam ações repressivas contra pequenos produtores com o fito de obter uma imagem de cumprimento de compromissos internacionalmente assumidos ao mesmo tempo em que garantiam a consolidação de preços monopolísticos ou oligopolísticos a grandes traficantes. Deste modo, enquanto que, aos poucos, organizavam-se estruturas oligárquicomilitares semelhantes a cartéis, camponeses indígenas obrigavam-se a suportar pragas químicas e condenações perpétuas salvo se vendessem àqueles a matériaprima do negócio a preços irrisórios ${ }^{231}$.

Ante a complexidade adquirida pelas redes de tráfico e sua notável penetração na burocracia de países centrais e periféricos por meio da corrupção, decerto não faltaria quem os supusesse decorrência de uma possível permissividade legislativa para com o tema. A verdade, porém, era oposta: o grande comércio de drogas se lia inexoravelmente à severidade repressiva, a qual permite que traficantes

\footnotetext{
${ }^{229}$ Idem, ibidem, p. 993. A pasta base é produzida mediante o amolecimento das folhas de coca com querosene e composições sulfuradas, extraindo-se-lhe a cocaína em uma proporção de cerca de $20 \%$ após lavagem com éter e acetona - solventes caros e de perigosa armazenagem e manipulação; a seu turno, o crack deriva da mera adição à pasta base de semelhante proporção bicarbonato de sódio, o que, além de significar um custo muito inferior, permite um rendimento cerca de dez vezes maior.

${ }^{230}$ Idem, ibidem, pp. 993-994.

${ }^{231}$ Idem, ibidem, pp. 995-997.
} 
que mantêm relações privilegiadas com agentes oficiais resguardem-se de concorrentes fustigados por um estatuto legal draconiano - assim ocorreu, e ainda ocorre, no sul da Ásia, no Oriente Médio, na América Latina, e, também, no varejo de países centrais ${ }^{232}$.

$\mathrm{O}$ resultado disso é que os EUA, que durante todo o século $\mathrm{XX}$ haviam fomentado a corrupção e a repressão desmedida nos países periféricos do continente $^{233}$, ora se viam diante de um subproduto daquelas suas políticas intervencionistas, ainda que se pretendessem, novamente, apenas vítimas de uma invasão estrangeira (embora milhares de seus cidadãos também se ocupassem do tráfico em países latino-americanos). Rapidamente, o poder de sedução do tráfico unira nas mesmas atividades americanos do norte, do centro e do sul, anti-castristas e castristas, sandinistas e contras, guerrilhas e oligarquias; contudo, a maior parte dos bilhões de dólares anuais que lhe correspondiam acabavam em bancos europeus, quando não reintroduzidos sem maiores problemas na economia estadunidense ${ }^{234}$.

A notável promiscuidade entre órgãos americanos de segurança e inteligência e traficantes internacionais não constituiu óbice a que, repetindo uma práxis do passado, autoridades oficiais convenientemente associassem o tráfico a grupos políticos indesejáveis. No ano de 1984, Lewis Tambs, então embaixador estadunidense na Colômbia, asseverou haver ali uma perigosa associação entre tráfico de drogas e grupos políticos de esquerda, para cuja designação cunhou expressão que se tornaria célebre: o "narcoterror", ou "narcoterrorismo"235.

\footnotetext{
${ }^{232}$ Idem, ibidem, pp. 997-1000. Com efeito, inúmeros são os relatos de introdução de grandes quantidades de drogas nos EUA facilitada por altos dirigentes da CIA e outros agentes oficias especialmente de segurança nacional - que, quando não seduzidos pelos valores envolvidos no tráfico, aceitavam como inevitável tal facilitação com vistas a um objetivo outro, que muitas vezes envolvia o sustento de grupos anti-revolucionários através do intercâmbio de drogas por armas e influência política; assim, por exemplo, afirmou-se que grandes traficantes colombianos eram "inimigos $d a$ DEA mas amigos da CIA" (ibidem, pp. 1001-1003).

${ }^{233}$ Primeiro com a doutrina Monroe; depois, com o big stick e, por fim, com a teoria da contenção à ameaça comunista e a doutrina Truman.

${ }^{234}$ ESCOHOTADO. Antonio. Historia general de las drogas, $3^{\mathrm{a}}$ ed. Madrid: Espasa, 2000, pp. 9981000.

${ }^{235}$ GUÁQUETA, Alexandra. "Transformación y efectos de la cooperación antidrogas entre Colombia y Estados unidos (1970-2000)”. In: CAMACHO GUIZADO, Álvaro. Narcotráfico: Europa, EEUU, América Latina. Barcelona: Obreal - Universitat de Barcelona, 2007, p. 197. Da assertiva de Tambs igualmente derivaria o termo análogo narcoguerrilha, ainda hoje bastante usado.
} 
Em verdade, demais da corrupção de agentes do Estado, particularmente na Colômbia observava-se um amálgama entre tráfico de drogas e grupos paramilitares tanto de direita quanto de esquerda, os quais dividiam o controle do país imerso em uma duradoura guerra civil. No início daquele ano, porém, especulou-se que laboratórios de refino de cocaína interditados pela repressão oficial eram protegidos pelas $F A R C^{236}$, circunstância que, mesmo incomprovada ${ }^{237}$, resultou na aludida declaração ${ }^{238}$ - que, de resto, ao ser prodigamente reproduzida por imprensa, empresários morais e órgãos oficiais, legitimaria definitivamente aos norte-americanos a sua ingerência política e militar em toda a região andina e $\operatorname{adjacências~}^{239}$.

Internamente, com a ajuda decisiva das ações de repressão da $D E A$, na metade dos anos 80 a disseminação do uso do crack viria a significar, de fato, um real problema de saúde pública nos EUA. Em tempos de exacerbação do consumismo e de alta receptividade a novos estimulantes, ao passo que a cocaína simbolizara o luxo de ricos, a nova substância - muito mais barata, lucrativa e nociva - materializava o luxo de pobres e miseráveis que, por sua mesma condição sóciocultural, revelavam-se menos capazes de dosar o produto, e acabavam por consumi-

${ }^{236}$ Fuerzas Armadas Revolucionarias de Colombia.

${ }^{237}$ RODRIGUES, Thiago. Política e drogas nas Américas. São paulo: Educ - Fapesp, 2004, p. 266.

${ }^{238}$ GUÁQUETA, Alexandra. Op. cit., p. 197. Cite-se, ainda, que tal afirmação contrariou o governo do presidente Betancur, que se via em meio a delicadas negociações de paz com as $F A R C$, que então se inviabilizaram.

${ }^{239}$ Além das sabidamente inúmeras operações nos países andinos, exemplos importantes da atuação norte-americana com base em sua doutrina militarista e unilateralista de intervenções são as invasões de Granada, em 1983, e do Panamá, em 1989. Essa parece merecer especial destaque: após haverem invadido o país, causando cerca de 3 mil mortes, fuzileiros navais norte-americanos detiveram o seu presidente-ditador, Gal. Manuel Noriega, para posteriormente levá-lo a uma corte em Miami que o julgou e condenou a 40 anos de prisão - depois reduzidos a 30 - por associação para o tráfico de drogas; no entanto, poucos anos antes Noriega cumprira um relevante papel como intermediário de confiança da CIA no financiamento - através de "narcodólares" - da guerrilha de direita nicaragüense, os Contras (a respeito, vide, cada qual enfocando diferentes aspectos da invasão, bem como suas razões alegadas e latentes e as conexões do general com setores da inteligência dos EUA então capitaneada pelo vice-presidente Bush: ESCOHOTADO, Antonio. Op. cit., p. 1001-1003; 10071; RODRIGUES, Thiago. Op. cit., p. 258-262; 276-278; NEUMAN, Elias. La Legalización de las drogas, $3^{\mathrm{a}}$ ed. reestruct. e ampl.. Buenos Aires: Universidad, 2005, p. 107-111). Para os EUA, doravante, a América Latina deixava de ser apresentada como uma ameaça comunista - o argumento justificador de invasões e conspirações norte-americanas até então - para constituir uma ameaça à segurança por meio do narcotráfico, ou seja, uma novel forma de subversão - pode-se dizer, um crime internacional da nova ordem. Assim, no momento em que países latino-americanos voltavam a experimentar o regime democrático com o ocaso do autoritarismo neles vigente desde o recrudescimento da guerra fria nos anos 60, emergia, na visão estadunidense, nova ameaça grave ao bem comum, tratando-se o tráfico de drogas como uma ameaça institucional a todo o Continente Americano. 
lo até a exaustão ${ }^{240}$. Por esse motivo, torna-se tarefa árida determinar se a alta freqüência de intoxicações agudas verificada, em que se incluíam quadros de grande depauperação psicossomática e episódios delirantes, derivava da nocividade intrínseca do composto ou das pautas de uso por parte de consumidores vulneráveis $^{241}$. Todavia, o tratamento destinado à questão pelo mass media seguia $\mathrm{o}$ errôneo modelo estabelecido ao longo de todo o século, conferindo-lhe status de aterrorizante - e imprevisível - epidemia baseada em preferências espontâneas de usuários, e mantendo omissos os fatores causais reais daquele fenômeno ${ }^{242}$.

Retroalimentava-se o problema por via da desinformação. Outrossim, ainda se ecoava a idéia - cada vez mais anacrônica - de "ameaça vermelha" alardeada por alguns dos principais líderes políticos de então.

Sem embargo, em janeiro de 1986, declarava o presidente Reagan ser evidente a ligação entre o tráfico internacional de drogas, o terrorismo e governos aliados aos soviéticos, como Cuba e Nicarágua, referindo-se ao tráfico de drogas como "gêmeos diabólicos" que constituiriam a mais perigosa ameaça ao ocidente ${ }^{243}$. No mês de abril do mesmo ano, o gabinete presidencial editou a National Security Directive on Narcotics and National Security (NSDD-221), documento em que o governo manifestava oficialmente a

sua percepção de que a principal ameaça aos Estados Unidos e ao hemisfério ocidental passara a residir na simbiose entre terrorismo de esquerda e narcotráfico. [...] A NSDD-221 "diagnosticava" o problema da "narcosubversão" e expunha a necessidade imperiosa de que os Estados Unidos se defendessem (e defendessem o continente) da grande trama "narcoterrorista". 244

\footnotetext{
${ }^{240}$ ESCOHOTADO. Antonio. Op. cit., p. 1013-1014.

${ }^{241}$ Idem, ibidem, p. 1113. A título de comparação, lembra o autor que em 1976, quando da emergência da cocaína nos EUA, não houve sequer um único caso de intoxicação fatal em todo o país; em 1986, quando a droga emergente era o crack, o número de mortes foi de cerca de 600 apenas no primeiro semestre.

${ }^{242}$ Idem, ibidem, pp. 1113-1114. O mesmo raciocínio, assinala o autor, autorizaria também que os envenenamentos decorrentes da ingestão de álcool metílico e outras destilações perniciosas havidos duante os anos 20 fossem vistos como imprevisíveis e baseados em preferências espontâneas dos consumidores - e não como um subproduto da lei seca.

${ }^{243}$ MARSHALL, Jonathan; SCOTT, Peter D. Cocaine politics: drugs, armies and the CIA in Central America. Los Angeles: UCLA, 1991, p. 23. Apud RODRIGUES, Thiago. Política e drogas nas Américas. São Paulo: Educ - Fapesp, 2004, p. 268.

${ }^{244}$ RODRIGUES, Thiago. Op. cit., p. 268-269.
} 
Encontra-se explícita em tal documento a idéia de serem as drogas relevante ameaça à segurança nacional do país, e seu tráfico um fator de instabilidade para a nação. Assumia-se claramente o problema como questão geopolítica essencial, e que assim reclamava ser tratado. Era a justificativa final para o extraordinário recrudescimento das políticas afetas ao tema desde o início da década, e que se perenizaria ao depois mormente em administrações republicanas.

Com os EUA sob mais uma emergência moral, política, jurídica, militar e de saúde pública, aprovou-se em 1988, em Viena, a Convenção das Nações Unidas contra o Tráfico ilícito de Entorpecentes e Substâncias Psicotrópicas ${ }^{245}$. Esse documento marca o apogeu da aceitação global do proibicionismo ${ }^{246}$. Dessa maneira, foi possível inserir, em seu preâmbulo, a pueril idéia de "supressão" e "erradicação" do tráfico, bem como a pretensão de "eliminar as causas profundas [...] do uso indevido" de drogas ${ }^{247}$. O texto arrolou diversas modalidades delitivas relacionadas à produção, distribuição e posse para uso próprio de psicoativos, a fim de que se refletissem nas legislações internas dos Estados-partes ${ }^{248}$; ampliou formas de cooperação internacional judiciária e policial $^{249}$; e impôs o controle a substâncias utilizadas no processo produtivo de drogas, como o éter e a acetona ${ }^{250}$.

Também durante a década de 1980, a exemplo da substituição da cocaína por crack, novas substâncias sintéticas apareceriam no mercado como alternativa para o controle imposto sobre as que antes possuíam mais livre circulação. São, primeiramente, as designer drugs, ou "drogas sob medida", novos fármacos psicotrópicos feitos a partir de substâncias ordinariamente manipuladas em laboratórios - como anfetamínicos e outros estimulantes -, e que, até então, não se incluíam entre as substâncias proibidas. Uma vez consumidos de modo abusivo - em

\footnotetext{
${ }^{245}$ Disponível em: <http://www.unodc.org/pdf/convention_1988_en.pdf >. Acesso em: 10/01/2009.

246 Aceitação essa que, em grande extensão, foi irrefletida, na medida em que a autoridade internacional funcionou, durante quase todo o século XX - considerando-se desde a predecessora Sociedade das Nações -, como mera instância homologatória de proposições trazidas pela diplomacia norte-americana

${ }^{247}$ Consoante a tradução oficial do documento, texto anexo ao decreto $\mathrm{n}^{\circ}$ 154/91. Disponível em: <http://www.planalto.gov.br/ccivil_03/decreto/1990-1994/D0154.htm〉. Acesso em: 10/01/2009. Lembre-se que, para a autoridade internacional, o "uso indevido" consiste tão só no mero uso de substância ilegal. A convenção, outrossim, ainda dedicaria um artigo inteiro ao tema das "medidas para erradicar o cultivo ilícito de plantas das quais se extraem entorpecentes e para eliminar a demanda ilícita de entorpecentes e substâncias psicotrópicas" (art. 14).

${ }^{248}$ Art. 3.

${ }^{249}$ Arts. 6 usque 11

${ }^{250}$ Art. 12.
} 
certa medida por desconhecimento de suas potencialidades -, apresentaram elevado grau de toxicidade, tendo sido responsabilizados pelos primeiros sintomas de Parkinson observados em jovens ${ }^{251}$. De outra parte, reapareceria, a partir de experimentos médicos havidos em grandes universidades ${ }^{252}$, o $\operatorname{MDMA}^{253}$ - ou ecstasy -, que, visto como uma alternativa terapêutica às drogas alucinógenas, logo seria igualmente adotado por movimentos alternativos como o new age californiano, e começou a ser utilizado recreativamente em pequena escala até chamar atenção da $D E A$. Esta, a despeito da inicial inocuidade e da utilização psicoterapêutica do psicotrópico, rapidamente logrou inseri-lo na lista de substâncias proibidas ${ }^{254}$. Disso resultou o exponencial aumento de seu preço, e, conseqüentemente, a emergência de um relevante interesse em seu tráfico, acompanhada de adulterações em sua composição; em seguida, adviriam os casos de abuso ${ }^{255}$.

Os casos do crack, das designer drugs e do ecstasy significaram o surgimento, a partir dos países centrais, de um novo e importante fenômeno característico de seu tempo: o das "drogas sucedâneas" "256, as quais tinham em comum o fato de terem nascido como alternativa a drogas proscritas existentes. Tal circunstância, deveras, fez com que o seu mercado - tanto do ponto de vista da demanda quanto da oferta - derivasse diretamente das políticas proibicionistas. Assim, afirma-se que essas drogas

nasceram da proibição, e subsistem quase exclusivamente graças a ela. Ao mesmo tempo, medem a capacidade de resposta que o mercado negro e a imaginação rebelde podem opor a medidas repressivas. [...] em apenas uma década surgiram vários sucedâneos potentes, baratos e simples de se produzir para cada uma das drogas ilícitas prévias $^{257}$.

\footnotetext{
${ }^{251}$ ESCOHOTADO, Antonio. Historia general de las drogas, $3^{\text {a }}$ ed. Madrid: Espasa, 2000, p. 10051009.

${ }^{252}$ Sabe-se que a composição fora sintetizada em 1912 nos laboratórios da Merck, mas permaneceu sem despertar maior interesse durante quase todo o século, até que cientistas de univesidades como Harvard e Cambridge intensificassem pesquisas respeitantes. A respeito, vide: FREUDENMANN, Roland W.; OXLER, Florian; BERNSCHNEIDER-REIF, Sabine. "The Origin of MDMA (ecstasy) revisited: the true story reconstructed from the original documents". Disponível em: http://www.mdma.net/merck/ecstasy-mdma.pdf>. Acesso em: 12/01/2009; ESCOHOTADO, Antonio. Op. cit., p. 1019-1022.

${ }^{253} 3,4$ metilenodioximetanfetamina.

${ }^{254}$ ESCOHOTADO, Antonio. Op. Cit., p. 1019-1023.

${ }^{255}$ Idem, ibidem, p. 1022-1029.

${ }^{256}$ Idem, ibidem, p. 1005.

${ }^{257}$ Idem, ibidem, p. 1017.
} 
De fato, a proibição seguia a operar como grande fator de expansão do mercado ilegal, cuja definitiva explosão sucedeu precisamente nos tempos de maior recrudescimento repressivo: os anos 80 .

O decênio seguinte testemunhou a continuidade das políticas consagradas na Convenção de Viena. Conquanto a administração democrata dos EUA houvesse moderado o tom belicoso dos anos anteriores, a abordagem obscurantista, em linhas gerais, permaneceu a mesma ${ }^{258}$, bem como as políticas intervencionistas sobre países produtores - cujo maior exemplo foi, sabe-se, o Plano Colômbia ${ }^{259}$.

Por outro lado, desde a década de 1990 desenvolveram-se foros de discussão objetiva do tema em diversos países, impulsionados notadamente por instituições acadêmicas e órgãos não-governamentais; outrossim, prosperaram algumas iniciativas políticas liberalizantes, como os casos de permissões legislativas para o uso médico da cannabis $^{260}$ e das políticas de redução de danos - de que nos ocuparemos mais adiante. Mesmo nos EUA, responsáveis pela difusão e patrocínio da proibição em todo o mundo e onde durante grande parte do século o assunto fora um tabu político intransponível ${ }^{261}$, objeções ao war on drugs deixariam de ver-se circunscritas a minorias radicais do partido democrata, alcançando até mesmo grupos conservadores influentes. Em 1996, o líder republicano no Congresso, Newton Gingrich, adjetivou como ruinosos os resultados da guerra capitaneada por seu país; pouco antes, o financista George Soros dotara com US\$ 10 milhões uma fundação com o escopo de promover o anti-proibicionismo. Assim, subsidiando-se em idéias

\footnotetext{
${ }^{258}$ Idem, ibidem, p. 1085.

${ }^{259}$ A respeito, vide: NEUMAN, Elias. La Legalización de las drogas, $3^{\mathrm{a}}$ ed. reestruct. e ampl.. Buenos Aires: Universidad, 2005, p. 162-168; FUCILLE, Luís Alexandre. "Plano Colômbia: o mito da militarização contra as drogas e seu impacto no plano estatal. In: Estudios politicos militares, ano 2, $\mathrm{n}^{\circ}$ 3, . Santiago de Chile: Universidad Arcis, jun/2002, p. 39-54.

260 Acerca da potencial utilização da cannabis para fins tera pêuticos, mencionando os debates travadosa respeito no Canadá, Reino Unido e alguns estados dos EUA a partir de meados dos a nos 90, vide: FRENOPOULO, Christian. "Issues in the biomedic al approach to the use of cannabis as a medication". Disponível em: বhttp://www.neip.info/index.php/content/view/90.html\#et>. Acesso em: 10/01/2009.

${ }^{261}$ Ilustrativamente, lembre-se que, desde o Marijuana Tax Act até a "declaração de guerra" de Nixon, portanto entre 1937 e 1971, todas as dezenas de decisões das casas do Congresso em matéria de controle de drogas foram, sem exceção, aprovadas por unanimidade, o que "mostra até que ponto será para os deputados e senadores um ato de lesa majestade eleitoralista e, portanto, um suicídio político qualquer gesto distinto do máximo rigor". ESCOHOTADO, Antonio. Op. cit., p. 697. Trad. livre.
} 
dos economistas liberais da escola de Chicago - entre os quais se incluiu Milton Friedman -, esses defensores do fim da proibição invocam

\begin{abstract}
razões praticamente idênticas às que se esgrimiram em 1933 contra a lei seca: em vez de suprimir ou sequer reduzir substancialmente o tráfico e o consumo de certas drogas, os gigantescos gastos sociais, policiais, judiciários e penitenciários derivados da manutenção da legislação vigente só têm servido para infiltrar cada vez mais a ilegalidade nas instituições ${ }^{262}$.
\end{abstract}

Isso não significou, entretanto, ter havido qualquer refluxo na defesa institucional da guerra às drogas, mas apenas, efetivamente, algumas contestações pontuais que antes sequer se permitia haver.

Em junho de 1998, reuniu-se para tratar do tema em sessão especial a Assembléia Geral das Nações Unidas. Coerentemente com a posição adotada pela organização desde muito, os debates ali travados careceram de análises críticas aprofundadas, as quais se quedaram preteridas em prol da obtenção de um consenso formal para a elaboração de uma declaração política ${ }^{263}$. Chegou-se a estabelecer no texto aprovado uma ilusória meta de 10 anos para a eliminação parcial ou total de cultivares ilícitos em todo o mundo ${ }^{264}$ - algo que, hoje, a própria ONU parece reconhecer impossível mesmo que a qualquer tempo -, bem como a drástica redução na demanda ${ }^{265}$.

Nos anos iniciais do novo século, prossegue o império do proibicionismo em todo o mundo - embora, em uma escassa quantidade de países, haja sido limitadamente relativizado ${ }^{266}$. Jamais, até hoje, o EUA sinalizaram qualquer mudança significativa em suas políticas, e, conseqüentemente, ainda que se verifique um relativo consenso entre acadêmicos, think-tanks e autoridades de diferentes países acerca do fracasso do modelo político-jurídico consagrado pelo war

\footnotetext{
${ }^{262}$ Idem, ibidem, p. 1086-1087.

${ }^{263}$ Disponível em: <http://un.org/ga/20special/poldecla.htm>. Acesso em: 10/01/2009. Fez-se sentir na assembléia, entretanto, o nascente influxo de um discurso alternativo europeu, mais pragmático e menos contaminado por ideologias no tratamento político da questão. Todavia, posições progressistas como a defesa das políticas de redução de danos não deixaram de ser objeto censura na reunião patrocinada pela autoridade internacional. A respeito, vide: BOEKHOUT VAN SOLINGE, Tim. Drugs and decision-making in the European Union. Trad. Berveley Jackson. Amsterdam: Mets \& Schilt - CEDRO, 2002, p. 15.

$264 \S \S 14$ et 19.

$265 \$ 17$.

${ }^{266}$ Especialmente no Continente Europeu, que será analisado em capítulo próprio.
} 
on drugs, parcos são os progressos emanados da autoridade internacional submetida à decisiva influência estadunidense.

Com efeito, e sempre desde o centro para a periferia econômica mundial, a partir dos anos 80 a guerra às drogas logrou substituir a guerra fria no ideário de combate permanente a um inimigo - interno e/ou externo - comum, que tanto marcou a história da política norte-americana. A seu turno, o intervencionismo externo próprio do war on drugs reaganiano permaneceu nas décadas que se lhe seguiram, podendo-se afirmar que, mais recentemente, o combate ao narcotráfico e ao terrorismo (ou narcoterrorismo) na região oculta o propósito latente de acesso e ingerência estadunidense sobre os recursos naturais da região ${ }^{267}$.

Por outro lado, é de se ver que a avalanche propagandista políticoideológica que, na era Reagan-Bush dos anos 80, caracterizou o auge da guerra às drogas, perdeu considerável espaço na pauta jornalística e nos discursos oficiais desde o 11 de Setembro de 2001, ofuscada que foi pela temática do war on terror de George W. Bush.

Sob os auspícios da ONU, em meados de 2008 autoridades internacionais reuniram-se em Viena para analisar o cumprimento das metas estabelecidas na declaração de 1998 e revisá-las no que pareça devido ${ }^{268}$. Deste encontro, cuja finalização dar-se-á em março de 2009, espera-se que as partes envolvidas obtenham avaliações e proposições mais maduras e realistas, condizentes com a noção de que a guerra às drogas é, mais que desnecessária, equivocada em suas premissas e destinada ao fracasso - pelo que se impõe à comunidade internacional a busca de modelos alternativos de política jurídica e social.

\footnotetext{
${ }^{267}$ Note-se que a Colômbia é grande fornecedora de energia aos EUA, além de deter a segunda maior biodiversidade do continente. A respeito: GUZZI, André Cavalles. As Relações EUA - América Latina: medidas e conseqüências da política externa norte-americana para combater a produção e o tráfico de drogas ilícitas. Dissertação de mestrado apresentada ao programa inter-institucional de relações internacionais San Tiago Dantas (PUC-SP - Unesp - Unicamp). São Paulo: 2008, p. 110. Assinala o autor que a execução do ambicioso Plano Colômbia não resultou, porém, em grandes avanços na prevenção da oferta de drogas, porquanto a ênfase dedicada ao militarismo e ao combate a grupos guerrilheiros suplantou a necessidade de implementação de programas de desenvolvimento alternativo nas regiões cultivadas (p. 110-111).

${ }^{268}$ Os trabalhos da reunião são divididos em cinco fóruns inter-governamentais de discussão, cada qual sobre um tema: redução da oferta, redução da demanda, erradicação de cultivares e desenvolvimento alternativo, lavagem de valores e análise de precursores e estimulantes anfetamínicos - a grande preocupação atual dos países centrais em matéria de psicoativos. A respeito, vide: 〈http://www.idpc.info/ungass.php>.
} 


\section{O MODELO LEGISLATIVO POSITIVO DA REPRESSÃO ÀS DROGAS}

No Brasil, a política criminal de drogas é determinada pela Lei $\mathrm{n}^{\circ}$ 11.343, de 23 de agosto de 2006, que substituiu os antigos diplomas atinentes ao assunto, a Lei 6.368/76 e a Lei 10.409/02, ambas revogadas por completo.

A modificação da legislação até então vigente era sabidamente desejada por grande parte dos estudiosos das ciências médicas, sociais e criminais, visto que a ênfase quase absoluta na repressão não resultara na eficácia preventiva almejada, e originava diversos outros problemas sociais. Entre estes, vale mencionar a estigmatização e a marginalização social, o inchaço do sistema penal, a obstrução à implementação de programas preventivos de eficácia comprovada - como o caso da redução de danos.

No entanto, a despeito do alarde mediático que se verificou ao tempo de sua promulgação - em virtude da não previsão de pena privativa de liberdade para as condutas afetas ao usuário -, do ponto de vista jurídico-penal e político-criminal o novel diploma não representou um avanço legislativo relevante.

Deveras, frustrando as expectativas da academia, o capítulo da Lei 11.343/06 atinente aos crimes e penas (cap. III) apresentou alterações pouco significativas em comparação ao que se via na antiga Lei de Tóxicos (Lei 6.368/76). É certo que o art. 28 progrediu em relação ao diploma antigo ao excluir a cominação de pena corporal para a conduta de posse de drogas para uso próprio, e, principalmente, ao retirar do rol de condutas análogas ao tráfico o cultivo, semeio ou colheita de plantas em pequenas quantidades com o fim de consumir a droga correspondente. É certo, igualmente, que o art. 33, que cuida do tráfico e condutas análogas, conferiu tratamento menos gravoso à figura do cedente eventual em seu $\S$ $3^{\circ}$, ao qual se estatuiu pena de seis meses a um ano de detenção.

Nada disso, porém, exclui a manifesta ideologia repressiva da lei. Em verdade, a não-incidência de pena privativa de liberdade ao usuário já era consabida realidade em nossa práxis judiciária, sobretudo após o advento da Lei 9.099/95 e, mais tarde, da Lei 10.259/01, que possibilitaram a suspensão condicional do processo e a transação penal para a figura do art. 16 do diploma antigo. Ainda, a previsão do 
art. $28, \S 2^{\circ}$, segundo a qual cabe ao juiz recorrer à "natureza e quantidade da substância apreendida, ao local e às condições em que se desenvolveu a ação, às circunstâncias sociais e pessoais, bem como à conduta e aos antecedentes do agente" para determinar se se trata de posse para uso ou para comércio da droga, constitui exemplo típico de um abominável direito penal de autor ${ }^{269}$. Então, mantendo-se o caráter penal da tutela da posse de drogas para uso próprio, manteve-se o tratamento estigmatizante que lhe era imposto.

É de se ver que a Lei 11.343/06 atribui sanções extremamente severas a tipos penais de mera periculosidade abstrata que, alegadamente, visam a tutelar um bem jurídico coletivo de escassa referência a seus supostos titulares - especialmente no caso da tutela penal das drogas. Assim, a não diferenciação, no tipo do art. 33, entre a figura do traficante-usuário, a do traficante de varejo e a do grande traficante, somada à elevação da pena mínima cominada para tais delitos, de três para cinco anos de reclusão, constitui comportamento irresponsável do legislador, que demonstrou parco desconhecimento da realidade que é objeto do tratamento legal ${ }^{270}$. A notável pluralidade de condutas que são equiparadas à figura do tráfico de drogas segue a implicar a ampliação do programa criminalizador em matéria de drogas, punindo atos preparatórios com vistas à almejada punição do grande traficante, e torna difícil a compreensão clara do alcance da norma.

Sem esclarecer o conteúdo semântico do vocábulo droga para seus propósitos, a legislação pátria impõe uma pena semelhante àquela prevista para o homicídio simples para qualquer um que importe, exporte, remeta, prepare, produza, fabrique, adquira, venda, exponha à venda, ofereça, tenha em depósito, transporte, traga consigo, guarde, prescreva, ministre, entregue a consumo ou forneça drogas ou seus precursores desautorizadamente, ainda que de forma gratuita, bem como a quem facilite o tráfico ilícito ou a quem semeie, cultive ou colha desautorizadamente plantas de que se extraem drogas. Deveras, basta um olhar sobre os núcleos do tipo penal do art. 33 da Lei 11.343 para constatar-se a singularidade do modelo de

269 PASCHOAL, Janaína Conceição. “A Importância do encontro sobre drogas: aspectos penais e criminológicos”. In: REALE JR., Miguel. PASCHOAL, Janaína Conceição. Drogas: aspectos penais e criminológicos - primeiro encontro de mestres e doutores do Departamento de Direito Penal da Faculdade de Direito da USP. Rio de Janeiro: Forense, 2005, p. 03.

${ }^{270}$ Idem, ibidem, p. 02-03. Note-se que a autora manifestou suas censuras ao atual modelo repressivo ainda no tempo em que o texto ainda tramitava no Congresso Nacional, sob a forma do Projeto de Lei $7.134 / 02$. 
repressivo sobre drogas que é assimilado acriticamente desde disposições de documentos internacionais que pouco se preocupam em compatibilizar-se com a evolução da ciência conjunta do direito penal contemporânea.

Não é objeto deste trabalho a exegese dogmática da legislação positiva, mas a ilegitimidade sob diferentes prismas da repressão penal imposta às drogas e aos cidadãos que com elas se relacionam, e a busca de alternativas. Por isso, deixam-se de lado as inúmeras críticas que se poderia fazer, especificamente, a cada tipo penal previsto na lei de drogas. Há que se observar, contudo, tratar-se de um modelo de criminalização que, a olhos vistos, apresenta dificuldades de adequação aos limites e fins do direito penal do Estado democrático e social de direito, cuja análise, ainda que breve, importa ao trabalho.

\subsection{Tutela de drogas e principiologia penal}

Em linhas gerais, entende-se o direito penal como o conjunto das normas jurídicas que relacionam comportamentos humanos - os crimes - a determinadas conseqüências jurídicas que lhe são próprias - as penas $-{ }^{271}$ somado ao saber que sistematiza a devida interpretação dessas normas ${ }^{272}$, e considera-se que possui como escopo salvaguardar valores fundamentais para a vida humana individual ou coletiva, sem cuja proteção a convivência em sociedade tornar-se-ia inviável. Nessa medida, costuma-se assinalar que a principal tarefa do direito penal reside na proteção de bens jurídicos ${ }^{273}$ fundamentais contra determinadas ofensas -

\footnotetext{
${ }^{271}$ DIAS, Jorge de Figueiredo. Direito penal: parte geral, t. 1, $1^{\text {a }}$ ed. bras., $2^{\text {a }}$ ed. port. São Paulo Coimbra: Revista dos Tribunais - Coimbra Editora, 2007, p. 03. Lembra o autor a necessária ressalva que há que ser feita sobre este entendimento, na medida em que, se de um lado a pena em sentido estrito não é a única conseqüência jurídica estatuída pelo direito penal sobre os comportamentos eleitos para sua tutela, havendo igualmente a medida de segurança, tampouco se pode falar em crime acerca do comportamento que esta pressupõe, porquanto lhe falta elemento essencial estruturante do delito: a culpabilidade (idem, ibidem, p. 03-04).

${ }^{272}$ ZAFFARONI, Eugenio Raúl; PIERANGELI, José Henrique. Manual de direito penal brasileiro parte geral, $5^{a}$ ed. rev. e atual. São Paulo: Revista dos Tribunais, 2004, p. 84.

${ }^{273}$ POLAINO NAVARRETE, Miguel. Derecho penal - parte general, t. II. Barcelona: Bosch, 2000, p. 554; CEREZO MIR, José. Derecho penal: parte general. São Paulo: Revista dos Tribunais, 2007, p. 25; ZAFFARONI, Eugenio Raúl; PIERANGELI, José Henrique. Op. cit., pp. 84-85; TOLEDO, Francisco de Assis. Princípios básicos de direito penal, $5^{\mathrm{a}}$ ed., $7^{\mathrm{a}}$ tir. São Paulo: Saraiva, 2000, pp. 1314. DOTTI, René Ariel. Curso de direito penal: parte geral. Rio de Janeiro: Forense, 2001, p. 03; PRADO, Luiz Regis. Bem jurídico-penal e Constituição, $3^{\mathrm{a}}$ ed. rev., atual. e ampl. São Paulo: Revista dos Tribunais, 2003, p. 65.
} 
reais ou potenciais - que lhe sejam intoleráveis, pelo que se chega à sintética idéia de que ao direito penal incumbe a tutela subsidiária de bens jurídicos ${ }^{274}$ indispensáveis à garantia da dignidade humana ${ }^{275} \mathrm{e}$ da coexistência social.

Uma vez que traduz a mais intensa modalidade de intervenção estatal a constringir a liberdade individual do cidadão, a atuação do direito penal consubstancia, portanto, uma maneira violenta de se lidar com problemas que, a seu turno, também denotam violência ${ }^{276}$. Dados esse imanente conteúdo de violência institucional e as indesejáveis consequiências sociais que daí decorrem, sua incidência há que ser limitada a situações em que tal modalidade de tutela se revele estritamente necessária para os fins de conservação de uma convivência social relativamente harmônica. Por essa razão, estabelece-se uma série de princípios limitadores à sua atuação, frutos da evolução histórica das ciências criminais.

Os princípios fundamentais do direito penal, ao mesmo tempo em que visam a limitar as hipóteses de sua violenta atuação e propiciar o sentimento de segurança jurídica indispensável ao desenvolvimento das relações sociais, prestam-se para justificar materialmente a intervenção estatal sobre a esfera de liberdade do cidadão. De sua adequada observância depende, portanto, a própria legitimidade da intervenção penal sobre cada caso específico.

No que se refere à criminalização das relações entre drogas e seres humanos, muitos são os questionamentos que se põem na análise de sua adequação a esses princípios fundamentais, o que desafia a legitimidade da intervenção penal nessa seara.

\footnotetext{
${ }^{274}$ ROXIN, Claus; ARZT, Gunther; TIEDEMANN, Klaus. Introdução ao direito penal e ao direito processual penal. Trad. Gercélia B. de Oliveira Mendes. Belo Horizonte: Del Rey, 2007, p. 08. DIAS, Jorge de Figueiredo. Op. cit., pp. 113-114. Zaffaroni e Batista, contudo, apontam-lhe alguma imprecisão conceitual na medida em que a lei penal não teria o condão de, efetivamente, tutelar um bem jurídico, mas apenas se prestaria a confiscar um conflito que atinja ou coloque em perigo um tal bem: "é óbvio que no homicídio não se tutela com a pena a vida da vítima [...] a idéia de bem jurídico tutelado digere e neutraliza o efeito limitador da idéia de bem jurídico lesionado ou exposto a perigo", pela qual os autores manifestam preferência (ZAFFARONI, Eugenio Raúl; BATISTA, Nilo; ALAGIA, Alejandro; SLOKAR, Alejandro. Direito penal brasileiro, vol. I, $2^{\mathrm{a}}$ ed. Rio de Janeiro: Revan, 2003, p. 227). Sem embargo, opta-se neste trabalho por se manter a terminologia conceitual apresentada, até para não se afastar em demasia de seu escopo fundamental.

${ }_{275}$ BOTTINI, Pierpaolo Cruz. Crimes de perigo abstrato e princípio da precaução na sociedade de risco. São Paulo: Revista dos Tribunais, 2007, p. 202.

${ }^{276}$ MUÑOZ CONDE, Francisco. Direito penal e controle social. Trad. Cíntia Toledo Miranda Chaves. Rio de Janeiro: Forense, 2005, p. 03.
} 
Assim sendo, desatende-se ao princípio da lesividade na medida em que, se tenciona sancionar as condutas nucleares típicas sem que haja qualquer referência a uma mínima exposição a perigo do bem jurídico tutelado, a saúde pública $^{277}$. Ora, não se pode presumir que o cultivo, cessão ou comercialização de uma quantidade qualquer de droga a terceiro exponha a perigo de lesão significante sequer a saúde individual, tanto menos a saúde pública. Inexiste, evidentemente, causação de perigo comum. Ademais, se não há lesividade, tampouco se pode especular sobre a observância aos princípios da subsidiariedade e da fragmentariedade do direito penal - o que não impede, entretanto, que se suponha hipotética observância daquele para a análise do eventual atendimento a estes.

O princípio da subsidiariedade impõe a comprovação de que não há outras maneiras de proteção do bem jurídico além da tutela penal. No caso da tutela de drogas, porém, a proibição "não só não considera as alternativas existentes [as quais, aliás, serão abordadas oportunamente], como ainda afeta negativamente os sistemas terapêutico-assistencial e informativo-educativo"278.

A seu turno, o princípio da fragmentariedade implicaria a incriminação somente das lesões mais gravosas à saúde pública que pudessem ser acarretadas pelas interações entre seres humanos e substâncias psicoativas. No entanto, em matéria de repressão às drogas, verifica-se a imposição arbitrária de crimes e penas a todas e quaisquer relações entre pessoas e substâncias, inclusive as mais inócuas, pelo que se despreza igualmente o princípio da intervenção mínima em matéria de drogas, a intervenção penal é máxima.

Do ponto de vista do princípio da legalidade, a amplitude do programa criminalizador de drogas reclama o estabelecimento de tipos abertos, normas penais em branco, redações vagas e indeterminadas - e confusas, dada a pouca técnica legislativa aplicada - com o escopo de abarcar toda sorte de conduta. Não se arriscam as legislações sequer a esclarecer o que deva ser entendido com droga, e tampouco descrevem, em todas as suas circunstâncias, quais são as condutas proibidas. No caso brasileiro, que lamentavelmente se repete em outros países, o

\footnotetext{
${ }^{277}$ RODRIGUES, Luciana Boiteux de Figueiredo. Controle penal sobre as drogas ilícitas: o impacto do proibicionismo no sistema penal e na sociedade. Tese de doutoramento apresentada à Faculdade de Direito da Universidade de São Paulo. São Paulo: 2006, p. 220.

${ }^{278}$ KARAM, Maria Lucia. De Crimes, penas e fantasias, $2^{\mathrm{a}}$ Ed. Rio de Janeiro: Luam, 1993, p. 63.
} 
recurso a norma regulamentar administrativa para se saber quais são as substâncias proibidas subtrai ainda mais a frágil segurança jurídica que se pode supor existente nos tipos incriminadores.

Por fim, a resoluta inobservância também do princípio da proporcionalidade queda-se evidente pela análise sistemática do direito penal, na medida em que a crimes indubitavelmente mais graves são dedicadas penas significativamente mais leves $-\mathrm{o}$ incêndio, a explosão e a inundação (respectivamente arts. 250, 251 e 254 do CP) possuem penas que variam de três a seis anos de reclusão; a provocação de desastre ferroviário (art. 260, $\S 1^{\circ}$ do CP) merece penas entre quatro e doze anos de privação da liberdade ${ }^{279}$.

As condutas do usuário, ademais, podem, no máximo, configurar espécie de autolesão, de todo impunível em nosso direito, sem qualquer repercussão, sequer potencial ou presumível, no plano da saúde pública. E querer protegê-lo de si mesmo, além de constituir flagrante desprezo à tutela constitucional da intimidade, da vida privada e do respeito à diferença - corolários do princípio da dignidade humana $-{ }^{280}$, seria de um paternalismo absolutamente incompatível com a concepção de uma sociedade formada por indivíduos adultos auto-responsáveis.

Como se vê, mesmo de uma análise bastante sintética do tema à luz dos princípios norteadores do direito penal é flagrante a ausência de dignidade penal $^{281}$ e de carência de tutela penal ${ }^{282}$ dos crimes de tráfico e posse de drogas, pelo que ambos restam inidôneos de um tal tratamento legislativo ${ }^{283}$. Não obstante,

\footnotetext{
279 Acerca da manifesta desproporcionalidade do crime de tráfico, vide: GRECO, Luís. "Tipos de autor e Lei de Tóxicos ou: interpretando democraticamente uma lei penal autoritária" In: Revista Brasileira de Ciências Criminais, ano 11, n. 43. São Paulo: Revista dos Tribunais, abr/jun 2003, p. 226 et. seq.

${ }^{280}$ Art. $1^{\circ}$, III e art. $5^{\circ}, \mathrm{X}$ da Constituição Federal. Acerca de sua aplicabilidade concreta à questão do uso de drogas, veja-se recente julgado do Tribunal de Justiça do Estado de São Paulo: TJSP, Apel. Crim. 01113563.3/0-0000-000, Rel. Juiz José Henrique Rodrigues Torres.

${ }^{281}$ Sobre a necessidade de haver-se dignidade penal para que um determinado valor possa ser objeto de tutela, vide: REALE JR., Miguel. Instituições de direito penal, vol. I. Rio de Janeiro: Forense, 2002 , p. 22.

${ }^{282}$ Sobre as noções de dignidade penal e carência de tutela penal, vide: ANDRADE, Manuel da Costa. "A Dignidade penal e a carência de tutela penal como referência de uma doutrina teleológico-racional do crime". In: Revista Portuguesa de Ciência Criminal, 2. Lisboa: abr/jun/1992, p. 173 et seq.

283 GOMES, Mariângela G. de Magalhães. "Notas sobre a inidoneidade constitucional da criminalização do porte e do comércio de drogas". In: REALE JR., Miguel. PASCHOAL, Janaína Conceição. Drogas: aspectos penais e criminológicos - primeiro encontro de mestres e doutores do
} 
também do ponto de vista da criminologia a intervenção penal sobre esses comportamentos é extremamente questionável.

\subsection{Algumas considerações de índole criminológica}

De acordo com a criminologia moderna, é preciso haver, necessariamente, o concurso de quatro requisitos para que se reconheça em determinada conduta a possibilidade de ser reconhecida coletivamente como crime: o fato deve ter incidência massiva no corpo social, real e efetiva incidência aflitiva, relevante persistência espaço-temporal e implicar inequívoco consenso acerca de sua etiologia e de técnicas de intervenção mais eficazes para seu controle ${ }^{284}$. Mediante esses critérios, tenciona-se evitar a criminalização de comportamentos isolados, socialmente inócuos ou efêmeros, ou mesmo que se promova uma incriminação inútil ou contraproducente.

No que toca à análise de tais requisitos, constata-se a cristalina falta às condutas relacionadas ao uso e ao tráfico de drogas de consenso inequívoco quanto à eficácia e justeza de seu tratamento penal, bem como, em muitos casos, carece igualmente de incidência aflitiva real ${ }^{285}$. Ainda, com base no quanto observado em capítulo anterior, mesmo a incidência massiva do fenômeno pode ser questionada, na medida em que parte dela poderia ser atribuível às próprias políticas repressivas.

De outra parte, o uso de drogas e, dependentemente da concepção que se adote, também o seu comércio, inserem-se na categoria dos "crimes sem vítimas" (victmless crimes), em que (i) a participação dos atores no fato é consensual; (ii) não há participantes demandantes pela proteção das agências penais; (iii) não há qualquer sentimento de dano por parte da suposta vítima; (iv) oferecem-se bens socialmente

Departamento de Direito Penal da Faculdade de Direito da USP. Rio de Janeiro: Forense, 2005, p. 94-106.

${ }^{284}$ SHECAIRA, Sérgio Salomão. Criminologia. São Paulo: Revista dos Tribunais, 2004, p. 43-47; GARCIA-PABLOS DE MOLINA, Antonio. Criminologia, $4^{\mathrm{a}}$ ed. São Paulo: Revista dos Tribunais, 2002, p. 71.

${ }^{285}$ Lembre-se que a quantidade de dependentes de drogas é extremamente pequena se comparada ao universo de pessoas que a consomem sem maiores implicações à sua vida pessoal a prefissional. 
desaprovados, mas amplamente desejados ${ }^{286}$. E, como é evidente, essa circunstância contribui para a ocorrência de uma notável disparidade entre a quantidade de delitos havidos e a quantidade de delitos de que se toma conhecimento em um determinado tempo e local, exsurgindo o fenômeno da cifra oculta da criminalidade (cifra negra).

Sob os mais diversos aspectos, portanto, somente se intensifica a deslegitimação do tratamento penal reservado às drogas, traficantes e usuários. Assim, utilizando-se da integração entre criminologia e direito penal no âmbito da ciência conjunta penal, manifesta-se a doutrina, respectivamente sobre os victmless crimes e a cifra oculta:

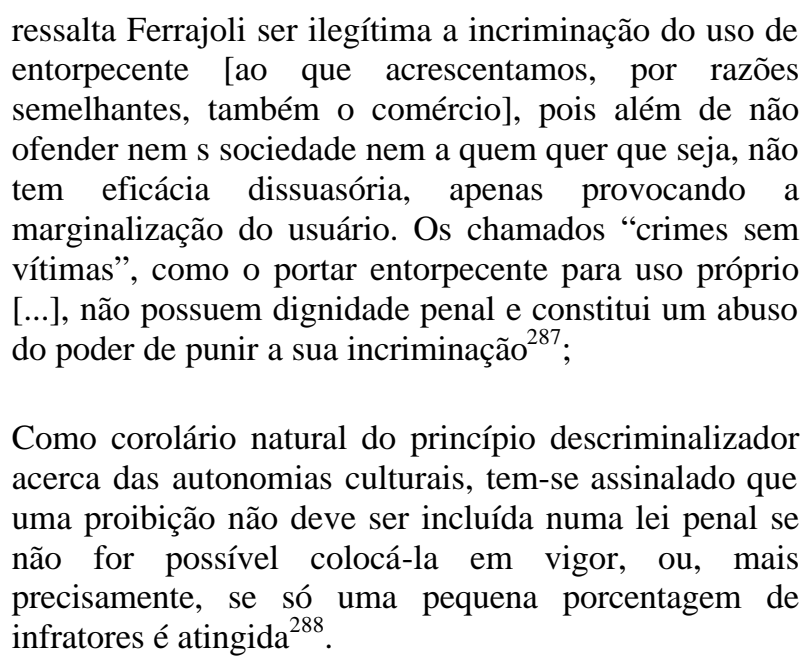

O fenômeno da cifra oculta, com efeito, agrava a seletividade do sistema punitivo, e escancara a maneira iníqua com que é ordinariamente aplicado pelas agências de repressão.

Há que se evitar a incriminação de condutas socialmente inócuas e/ou meramente protetoras de valores morais ${ }^{289}$, como ocorre no caso da tutela de drogas, se se almeja prevenir a acentuada estigmatização e marginalização de grupos sociais que não compartilhem dos mesmos códigos - das quais podem advir distúrbios

${ }^{286}$ CERVINI, Raul. Os Processos de descriminalização, $2^{\mathrm{a}}$ ed. Trad. Luiz Flávio Gomes. São Paulo: Revista dos Tribunais, 2002, p. 208.

${ }^{287}$ REALE JR., Miguel. Instituições de direito penal, vol. I. Rio de Janeiro: Forense, 2002, p. 25.

${ }^{288}$ CERVINI, Raul. Op. cit., p. 183.

${ }^{289}$ GARCIA-PABLOS DE MOLINA, Antonio. Criminologia, $4^{\mathrm{a}}$ ed. São Paulo: Revista dos Tribunais, 2002, p. 366. 
sociais conseguintes, como o caso das subculturas delinqüentes ${ }^{290}$ e das carreiras criminais $^{291}$.

Embora pareçam bastantes - e, de fato, sejam-no - os argumentos supra-expendidos, há ainda outros a serem tratados que demonstram, claramente, a ilegitimidade e a imprestabilidade do proibicionismo penal das drogas.

${ }^{290}$ Idem, ibidem, p. 363 et seq.; SHECAIRA, Sérgio Salomão. Criminologia. São Paulo: Revista dos Tribunais, 2005, p. 241 et seq.

${ }^{291}$ GARCIA-PABLOS DE MOLINA, Antonio. Op. Cit., p. 490-492; Nosso, "Breve estudo acerca da atuação das instâncias de controle social formal e informal”. In: Ultima Ratio, ano 1, n. 1. Rio de Janeiro: Lumen Juris, 2007, p. 499-500.. 


\section{LIBERDADE INDIVIDUAL VERSUS PATERNALISMO LEGAL}

Não obstante as flagrantes arbitrariedade e ilegitimidade constatadas nos critérios utilizados pelas instâncias oficiais para elegerem as drogas cujo consumo e distribuição lhes seja conveniente ${ }^{292}$, a atuação estatal no sentido de impedir o uso de determinados psicoativos pelos cidadãos ainda que estes os consumam exclusivamente em seu ambiente doméstico implica, independentemente de quais possam ser as substâncias escolhidas, a assunção por parte do Estado de uma tarefa/responsabilidade que talvez não lhe incumba.

Stuart Mill, filósofo e economista político britânico, já em 1859 afirmava ser o indivíduo naturalmente soberano acerca de si mesmo, de seu corpo e de sua mente ${ }^{293}$, que comporiam, juntos, inexcedível esfera de liberdade individual. Esse pensamento, a princípio, tenderia a reclamar a resoluta ilegitimidade da intervenção coercitiva estatal sobre o consumo de drogas, ao menos em âmbito doméstico. É certo, porém, que não caberia aceitar a sua aplicação prática absoluta, porque incompatível com a convivência em sociedade, mormente nos atuais tempos de relações sociais complexas ${ }^{294}$. Com efeito, a abolição de limites à liberdade individual, uma vez levada às últimas conseqüências, exigiria admitir-se a plena liberdade do indivíduo no que concerne, por exemplo, ao pagamento de tributos, ao uso de cinto de segurança em veículos automotores, ao uso de capacetes em motocicletas ou, mesmo, à escolha privada de limites de velocidade para o tráfego em vias públicas ${ }^{295}$ A consideração de Mill segundo a qual a única razão para a intervenção oficial sobre o comportamento humano residiria na causação de danos a terceiros - com a qual fundamentava o chamado harm to others principle ${ }^{296}$ a repelir

\footnotetext{
${ }^{292}$ Vide supra, cap. 3.

${ }^{293}$ MILL, John Stuart. On Liberty and other essays. Oxford: Oxford University Press, 1991, p. 14.

${ }^{294}$ Sobre a contextualização da vida atual na sociedade complexa, vide supra, item 4.1.1.

295 Convém anotar, de toda sorte, que as limitações impostas pelo Estado a tais liberdades é feita através da utilização de normas de controle meramente administrativo, não ocorrendo a aguda tutela penal - inclusive, evidentemente, no caso do não recolhimento de tributos, que necessariamente requer a concorrência do elemento fraude para que seja erigido à categoria de delito. A lógica não é a mesma, porém, no caso da intervenção estatal sobre os consumidores de psicoativos.

${ }^{296}$ Em português, 'princípio do dano a terceiro', ou, ainda, 'princípio da ofensa a terceiro'. MILL, John Stuart. Op. cit., chap. IV, passim. Cabe observar, aqui, que a concepção material de crime prevalente no pensamento jurídico anglo-americano desde o século XIX repousa justamente na doutrina do princípio do dano (harm principle), fundada nas idéias pioneiras de Stuart Mill e atualmente apoiada, em grande medida, no pensamento jusfilosófico de Feinberg. No direito europeu
} 
intervenções classificáveis de paternalistas -, entretanto, parece permitir que, sem necessariamente se opor ao seu pensamento nuclear, tencione-se legitimar a incriminação do mero consumo de drogas com base no argumento de sua pretendida nocividade social.

Em todo caso, é fato que uma desejada eticidade da intervenção punitiva estatal, em princípio, haveria que reclamar a abstenção do direito penal quanto à eventual punição de condutas de caráter essencialmente privado, como é o caso da autolesão deliberada ou da tentativa de suicídio ${ }^{297}$. A esse respeito, leciona-se que o paternalismo legal pressupõe que o Estado conheça melhor os interesses particulares dos cidadãos do que estes próprios os conhecem ${ }^{298}$, máxima que em nada parece razoável $^{299}$. Encontra-se circunscrita às fronteiras morais particulares da cada indivíduo a possibilidade de se autogovernar, de soberanamente autodeterminar-se, afigurando-se ilegítima a ingerência estatal em tal plano face às inextrincáveis relações entre a autodeterminação pessoal e o constitucionalmente protegido campo da privacidade individual ${ }^{300}$; entre a autodeterminação individual e a liberdade $d e$ facto. Assim sendo, não seria lícito ao Estado, sobretudo através do direito penal - o mais poderoso (e danoso) instrumento oficial de coerção -, ultrapassar essas barreiras atinentes à soberania do indivíduo-cidadão ${ }^{301}$.

As intervenções legais de índole paternalista apresentam duas características centrais: em primeiro lugar, visam a proteger um suposto interesse do próprio indivíduo por elas atingido; em segundo, contêm necessária coerção, pelo que não se

continental, por influência da doutrina penal italiana, o termo 'ofensividade' (offensività) obteve maior aceitação durante o desenvolvimento do conceito material do delito, acabando por se imbricar com a própria noção de proteção de bens jurídicos, consoante exposto supra (cap. 4.1). A respeito, vide: DIAS, Jorge de Figueiredo. Op. cit., pp. 109-110.

${ }^{297}$ Tais comportamentos, de fato, não são contemplados pela tutela do direito penal no Brasil e em grande parte dos demais países.

${ }^{298}$ FEINBERG, Joel. The Moral limits of the Criminal Law, vol. 3: Harm to self. Oxford: Oxford University Press, 1989, p. 23. Disponível [on-line] em: Oxford Scholarship Online, <http://oxfordscholarship.com/oso/public/content/philosophy/0195059239/toc.html〉. Acesso em: $13 / 09 / 2004$.

${ }^{299}$ Já tivemos oportunidade de nos manifestar introdutoriamente acerca do paternalismo legal, com apoio nas teses de Mill e Feinberg, em: TAFFARELlO, Rogério Fernando, Da Legalização das drogas como instrumento de política criminal. Tese de láurea apresentada à Faculdade de Direito da Universidade de São Paulo. São Paulo: FDUSP, 2004, pp. 70-71.

${ }^{300}$ Constituição Federal, art. $5^{\circ}$, esp. inc. IV, VI, VIII, IX, X e, por extensão, inc. XI e XII.

${ }^{301}$ TAFFARELLO, Rogério Fernando. Op. cit., p. 71. 
faculta ao atingido dissentir da intervenção que se lhe impõe ${ }^{302}$. Conquanto pretendam possuir um nobre propósito de proteção dos administrados, revelam-se temerárias à medida que esse propósito possa se prestar para ocultar outros de caráter questionável, como a salvaguarda de determinadas codificações morais que, consideradas em si mesmas, não se mostrariam dignas de tutela penal. Nessa medida, intervenções paternalistas não constituiriam senão um pretexto para a imposição ilegítima de padrões morais a indivíduos não submetidos a determinados modelos de comportamento desejados pelo status social dominante ${ }^{303}$. Independentemente, porém, de uma intervenção legal paternalista servir ou não a uma ocultação de seu verdadeiro propósito, é inegável que supõe a impossibilidade de se considerarem os indivíduos adultos componentes do tecido social como plenamente responsáveis pelos próprios atos e suas conseqüências. Desta constatação decorre, efetivamente, um certo e apriorístico - e, ademais, claramente justificado - ceticismo doutrinário ante a existência de intervenções penais paternalistas ${ }^{304}$.

Por conseqüência, mesmo aquelas pessoas que adotam um estilo de vida que possa ser considerado caótico para os padrões médios sociais devem ser vistas como sujeitos racionais e competentes para sua autodeterminação, com condições de desenvolverem uma concepção de vida própria e coerente com seus intentos, visto que dotados de possibilidades de auto-reflexão e assunção das responsabilidades implicadas por seus atos ${ }^{305}$.

Não se deve a priori estabelecer, contudo, que uma tal reflexão seja suficiente para definir eventual ilegitimidade de da intervenção penal sobre este ou aquele comportamento; deveras, há que se reconhecer a ocorrência de uma presunção contrária à validade e plausibilidade de qualquer intervenção que traga em seu bojo

\footnotetext{
${ }^{302}$ VON HIRSCH, Andrew. "Paternalismo direto: autolesões devem ser punidas penalmente?". Trad. Helena Regina Lobo da Costa. In: Revista Brasileira de Ciências Criminais, n. 67. São Paulo: Revista dos Tribunais, jul-ago/2007, p. 13.

${ }^{303}$ A esse respeito, manifestam-se Zaffaroni e Batista: "O estado que pretende impor uma moral é imoral, porque o mérito moral é fruto de uma escolha livre diante da possibilidade de optar por outra coisa: carece de mérito aquele que não pôde fazer alguma coisa diferente. Por essa razão, o estado paternalista é imoral. Em lugar de pretender impor uma moral, o estado ético deve reconhecer o âmbito de liberdade moral, possibilitando o mérito de seus cidadãos, que surge quando eles têm a disponibilidade da alternativa imoral [...]”. ZAFFARONI, Eugenio Raúl; BATISTA, Nilo; ALAGIA, Alejandro; SLOKAR, Alejandro. Op. cit., p. 225.

${ }^{304}$ VON HIRSCH, Andrew. Op. cit., p. 13.

${ }^{305}$ Idem, ibidem, p. 15.
} 
fortes contornos de paternalismo legal ${ }^{306}$. Todavia, uma intervenção que pareça meramente paternalista pode, de outra parte, ser legitimada por outros critérios igualmente idôneos a autorizar a tutela da norma penal $^{307}$, ainda que sua potencial legitimação se veja enfraquecida sob o ponto de vista filosófico-liberal ${ }^{308}$. É fato, outrossim, que sanções que se afigurem meramente paternalistas possam ter o legítimo escopo de tutelar situações em que pessoas, hipossuficientes em alguma medida, não hajam genuinamente consentido com o risco a que se expõem, o que torna inválido tal consentimento e reclama a proteção institucional de seu interesse $^{309}$. Tampouco se afirme, peremptoriamente, que, em casos em que se verifique a inaceitabilidade da intervenção jurídico-penal sobre a esfera de liberdade do cidadão, não possa haver o controle oficial através de outras formas menos agudas de regulação jurídica ${ }^{310}$; estas, ao revés, uma vez observando-se os demais princípios norteadores do direito punitivo em um Estado democrático e social, podem se mostrar bastante adequadas a certas situações determinadas.

Isso posto, importa investigar se a incriminação do porte de drogas para uso próprio constitui uma intervenção penal de cariz paternalista e, se o caso, examinar a sua legitimidade sob essa ótica.

Ora, na medida em que se propõe, fundamentalmente, a proteger o usuário de potenciais males que possam ser acarretados à sua saúde física e/ou psíquica,

\footnotetext{
${ }^{306}$ Idem, ibidem, p. 14.

${ }^{307}$ ESTELLITA, Heloisa. "Paternalismo, moralismo e direito penal: alguns crimes suspeitos em nosso direito positivo". In: Boletim do Instituto Brasileiro de Ciências Criminais, ano 15, n. 179. São Paulo: IBCCRIM, out/2007, p. 18.

${ }^{308}$ Idem, ibidem, p. 18.

${ }^{309}$ Idem, ibidem, pp. 17-18.

310 Apontando uma resistente carência de desenvolvimento doutrinário acerca do paternalismo legal em diversos aspectos, Von Hirsch lembra, inicialmente, que "a discussão sobre o paternalismo nos anos 80 deu pouca atenção à questão acerca de quais podem ser as diferenças fundamentais entre proibições paternalistas no direito penal e em outras formas de intervenções estatais coativas (exemplificativamente, as do direito civil ou do direito administrativo) que se direcionem a impedir comportamentos autoprejudiciais". VON HIRSCH, Andrew. Op. cit., p. 14. Mais à frente, pondera: "segundo meu julgamento, existem problemas específicos quando se acionam sanções penais, ainda que o modelo de um paternalismo limitado possa justificar intervenções coercitivas estatais de outras naturezas (por exemplo, de natureza civil ou administrativa)". Idem, ibidem, p. 18. E, finalmente, arremata: "Se minha argumentação anterior, que se concentrou na característica de censura da sanção e na inapropriação da censura penal para comportamentos autoprejudicias, está correta, seria possível argumentar que, tendo em vista, por exemplo, a baixa gravidade da sanção relativa à obrigação de usar cinto de segurança, não existiria uma reação verdadeiramente de censura nos termos do direito penal tradicional. No direito alemão, tais formas de comportamento seriam frequentemente consideradas infrações contra-ordenacionais (Ordnungswidrigkeiten) e não exprimiriam, por isso, uma verdadeira censura penal". Idem, ibidem, pp. 26-27.
} 
indiciariamente parece claro estar-se diante de um exemplo de indevida intervenção paternalista $^{311} \operatorname{direta}^{312}$. A questão se torna um pouco mais complexa se se considera que o âmbito de proteção da norma penal incriminadora do consumo de substâncias tóxicas deva se estender à prevenção de ofensas colaterais resultantes de tal consumo, como é o caso dos já observados males sociais que se supõe mantenham relação de simples causa/efeito com o uso de psicoativos. Trata-se aqui, portanto, de eventual prevenção de possíveis vitimizações futuras de terceiros, com o que o escopo da incriminação do porte de drogas para uso próprio passaria a albergar o evitamento de potenciais delitos como furtos, vandalismos, lesões corporais e até homicídios, entre outros. Nesse mister, discute-se se as lesões causadas mediatamente deveriam dar causa a uma antecipação da tutela penal com base na alegada natureza criminógena do consumo de psicoativos ${ }^{313}$.

Tal compreensão, entretanto, necessariamente implicaria a admissibilidade da responsabilização penal por fato futuro e incerto, seja ele próprio ou mesmo - e espantosamente - alheio. Ressalta-se na hipótese, desde logo, um flagrante conflito com o princípio da responsabilidade penal própria ${ }^{314}$, fundamental a um direito penal democrático $^{315}$, que estabelece ser a responsabilidade penal imputável a pessoas determinadas e em virtude de fatos determinados a que tenham dado causa ${ }^{316}$. Absolutamente, não se afigura razoável aceitar-se a incriminação de condutas pelo mero fato de possibilitarem eventuais lesões ulteriores sobre as quais o ator original

\footnotetext{
${ }^{311}$ ESTELLITA, Heloísa. Op. cit., p. 18.

312 Von Hirsch explica a diferença existente entre o paternalismo legal direto e o paternalismo indireto: enquanto que este tenciona proteger o interesse de uma pessoa ante lesão causada por outrem, ainda que genuinamente consentida, o primeiro pretensamente protege o interesse de alguém sobre eventual lesão causada por si próprio - razão pela qual o professor de Frankfurt e Cambridge não admite a sua justificação em sede de direito penal. VON HIRSCH, Andrew. Op. cit., esp. pp. 12$13 ; 23-26$.

${ }^{313}$ Idem, ibidem, p. 25.

${ }^{314}$ Idem, ibidem, p. 25. Sobre o fundamento do princípio da responsabilidade penal própria (pessoal), Cirino dos Santos, com referências a Baratta, aponta ser "a culpabilidade, como expressão do princípio nulla poena sine culpa (derivado do art. $5^{\circ}$, LXII, CR, que institui a presunção de inocência), indicada pelas condições pessoais de saber[-se] o que faz (imputabilidade), de conhecimento real do $q u e$ [se] fez (consciência da antijuridicidade), e do poder concreto de não [se] fazer o que [se] fez. (exigibilidade de comportamento diverso), que estruturam o juízo de reprovação do conceito normativo de culpabilidade: somente a culpabilidade pode fundamentar a responsabilidade penal pessoal para a realização do tipo de injusto". SANTOS, Juarez Cirino. Op. cit., pp. 31-32 (grifos do originial). Ainda a respeito do mesmo princípio, ora tratado como princípio da intranscendência ou transcendência mínima e compreendido de uma maneira mais ampla, vide: ZAFFARONI, Eugenio Raúl; BATISTA, Nilo; ALAGIA, Alejandro; SLOKAR, Alejandro. Op. cit., pp. 232-233.)

${ }^{315} \mathrm{E}$ que, de tão elementar e incontroverso, nem mesmo mereceu ser abordado no capítulo deste trabalho que discute a principiologia do direito penal (supra, cap. 4).

${ }^{316}$ A respeito, em nosso ordenamento, art. 13 do Código Penal.
} 
não detém controle ao tempo de sua ação, objeção que remanesce válida ainda que, mediante decisões futuras, o mesmo ator possa vir a concorrer para a prática de tais lesões ${ }^{317}$. Com isso, não se exclui a adequada e necessária responsabilização penal sobre casos em que o agente original, desde logo, apresente desígnio concorrente com a decisão futura de causação da ofensa; ao mesmo tempo, permite-se refutar toda intervenção estatal que revele a ilegítima expressão de um paternalismo penal direto $^{318}$.

${ }^{317}$ VON HIRSCH, Andrew. Op. cit., p. 26.

${ }^{318}$ Idem, ibidem, p. 26. 


\section{INEFICÁCIA MANIFESTA DA CRIMINALIZAÇÃO DO COMÉRCIO dE DROGAS ANTE OS FINS A QUE SE PROPÕE (o war on supply, o paradoxo dos lucros e o efeito hidra)}

Em estudo bastante profundo e acurado sobre o tema, Bertram et al desmistificam alguns dos falsos axiomas ligados à política repressiva estadunidense, demonstrando a sua patente ineficácia e a sua inegável contraproducência. Lembram os autores, inicialmente, que se podem dividir as estratégias políticas do chamado war on drugs em duas partes complementares: a guerra ao fornecimento (war on supply) e a guerra ao uso (war on use) de substâncias psicoativas, cada qual com suas respectivas - e inerentes - falhas, derivadas de sua própria concepção e $\operatorname{pressupostos}^{319}$. Enquanto que a guerra ao uso equivoca-se ao supor, de maneira extremamente simplista, que o simples temor da sanção penal teria poder dissuasório suficiente para evitar o consumo de drogas ${ }^{320}$, os equívocos da guerra ao fornecimento se apresentam mais complexos, baseados, especialmente, em duas questões-problema, respectivamente, o paradoxo dos lucros (profit paradox) e o efeito hidra (hydra effect) ${ }^{321}$. Ambos são conseqüências diretas das políticas da guerra às drogas.

O paradoxo dos lucros tem a sua gênese no fato de as políticas oficiais de combate à produção e circulação de drogas almejarem interferir no mercado dessas substâncias, tornando-as cada vez mais escassas e, com isso, caras. Com efeito, a repressão tem conseguido elevar os preços da oferta de psicoativos em virtude do conseguinte aumento dos custos operacionais de sua produção, bem como do incremento dos riscos experimentados por quem atua no mercado ilegal. No entanto, ocorre que, com a permanência da demanda por drogas - o que, pode-se arriscar-se a

\footnotetext{
319 BERTRAM, Eva; BLACHMAN, Morris; SHARPE, Kenneth; ANDREAS, Peter. Drug war politics: the price of denial. Berkeley - Los Angeles - London: University of California Press, 1996, pp. 09 et seq.

${ }^{320}$ A esse respeito, analisando criticamente cada uma das teorias sobre as finalidade da pena, Ferrajoli, ao tratar da prevenção geral negativa, assinala a sua ineficácia recorrendo, inclusive, ao caso do consumo de psicoativos como ilustração de seu argumento: “[...] inclusive no aborto ou no consumo de estupefacientes se admite que as penas, como parece demonstrado por investigações empíricas comparadas, são completamente ineficazes para preveni-los". FERRAJOLI, Luigi. Derecho y razón teoría del garantismo penal, $4^{\mathrm{a}}$ ed. Trad. Perfecto Andrés Ibáñez et. al. Madrid: Editorial Trotta, 2000, p. 280. Trad. livre do esp. para o port.

${ }^{321}$ BERTRAM, Eva; BLACHMAN, Morris; SHARPE, Kenneth; ANDREAS, Peter. Op. cit., p. 13 et seq.
} 
dizer, tem ocorrido de modo consistente em toda a história desde as primeiras descobertas de seus efeitos ${ }^{322}$-, sejam elas lícitas ou ilícitas, o seu mercado se torna extraordinariamente lucrativo para produtores, distribuidores e comerciantes, precisamente pelo fato de serem os produtos mais escassos - e mais caros - do que o seriam acaso não fossem proibidos ${ }^{323}$.

Tal fenômeno se deve, em grande medida, ao fato de que a curva de demanda no peculiar mercado das drogas, malgrado apresente variações de acordo com diferentes categorias de usuários ${ }^{324}$, tende a ser considerada preço-inelástica, ou de pouca elasticidade ${ }^{325}$. Disso decorre a limitada eficácia da promoção do incremento artificial nos preços para fins de contenção da demanda por drogas ${ }^{326}$, na medida em que o desejo de consumi-las é, no mais das vezes, suficientemente forte para se desconsiderarem os altos custos de seu consumo - ainda que, para se poder satisfazêlo, arrisque-se, por exemplo, a cometer um crime patrimonial ${ }^{327}$.

É de se observar que, sob o ponto de vista econômico, a dinâmica do mercado de drogas funciona semelhantemente à dinâmica de qualquer mercado de

${ }^{322}$ Vide supra, cap. 3.1 .
${ }^{323}$ A respeito, os pesquisadores da Universidade da Califórnia citam dois casos exemplares de seu
estudo de 1996 : à época, $1 \mathrm{~g}$ de cocaína pura, se adquirido legalmente para fins medicinais, custaria
entre US\$ 15,00 e US $\$ 20,00$, ao passo que, no mercado ilegal norte-americano, a mesma quantidade
sairia por um prelo médio de US $\$ 143,00$; de outra parte, constataram que os $330 \mathrm{~kg}$ de folhas de coca
necessários para se produzir $1 \mathrm{~kg}$ de cocaína pura rendiam cerca de US $\$ 110,00$ ao seu produtor rural
na Bolívia, e, após feito o seu processamento, refino e finalização, a mercadoria era vendida em
Miami, ainda no atacado, por algo entre US $\$ 16.000,00$ e US $\$ 25.000,00$, podendo chegar a atingir,
após fracionada em pequenas porções, no varejo das ruas das grandes cidades dos EUA, as
impressionantes cifras de entre US\$ $70.000,00$ e US\$ $300.000,00$. BERTRAM, Eva; BLACHMAN,
Morris; SHARPE, Kenneth; ANDREAS, Peter Op. cit., p. 12 et 15 .
324 Naturalmente, usuários em situação de dependência ou semi-dependência tendem a considerar
menos o preço da droga na decisão de sua compra do que usuários ocasionais ou potenciais novos usuários.

${ }^{325}$ BARTON, Adrian. Illicit drugs: use and control. London - New York: Routledge, 2003, pp. 92-93; KUZYEMKO, Ilyana; LEVITT, Steven David. "An empirical analysis of imprisioning drug offenders". In: Journal of Public Economics, n. 88. Lausanne: Elsevier - Thomson Scientific, 2004, pp. 2054-2055. Disponível [on-line] em: <http://pricetheory.uchicago.edu/levitt/Papers/KuziemkoLevitt2004.pdf>. Acesso em: 10/01/2008; STORTI, Cláudia Costa; DE GRAWE, Paul. "Globalization and the price decline of illicit drugs", p. 08. Disponível [on-line] em: <http://www.cesifogroup.de/pls/guestci/download/CESifo\%20Working\%20Papers\%202007/CESifo\%20Working\%20Pa pers\%20May\%202007/cesifo1_wp1990.pdf>. Acesso em: 10/01/2008.

326 Sobre o conceito econômico e estatístico de elasticidade-preço da demanda, vide: KHEMANI, Rughvir Shyam; SHAPIRO, Daniel M. Glossary of industrial organisation economics and Competition Law. Paris: OECD Directorate for Financial, Fiscal and Enterprise Affairs, 2002. pp. 4142. Disponível [on-line] em: <http://www.oecd.org/dataoecd/8/61/2376087.pdf>. Acesso em: $10 / 01 / 2008$.

${ }^{327}$ GOMES, Mariângela Gama de Magalhães. Op. cit., pp. 99-100. 
commodities, porquanto se rege fundamentalmente pela lei de oferta e demanda; por outro lado, apresenta idiossincrasias que lhe conferem um caráter particular, especialmente em virtude de dois fatores: a quase estática elasticidade-preço da demanda, de um lado, e a sua ilicitude, de outro. E a concorrência de tais fatores propicia o influxo do fenômeno ora analisado: o aumento dos riscos do negócio e a manutenção do interesse pelo produto implicam um grandioso incremento nas margens de lucro do mercado ilegal, conseqüência direta da proibição oficial. Desta forma, quanto mais exitosas as movimentações estatais no sentido da repressão, tanto maiores resultam os lucros obtidos; estes, a seu turno, funcionam como um enorme incentivo a que os atores do citado mercado nele permaneçam, e a que outros negociantes nele se iniciem. E porque se mantém, a despeito de todos os esforços institucionais, uma considerável oferta do produto no varejo, os preços, conquanto elevados, jamais atingem patamares suficientemente altos para fazerem cessar a demanda latente por psicoativos. Paradoxalmente, as próprias estratégias políticas de combate às drogas acabam por minar a si próprias, na medida em que o aumento de preços por elas almejado é suficiente para seduzir os seus negociantes, mas insuficiente para afastar os seus consumidores ${ }^{328}$.

Com isso, apesar de as crescentes apreensões de drogas das últimas décadas impressionarem, revelam-se pouco significativas para cumprir as pretensões de enfraquecimento da produção e circulação de tais mercadorias: estima-se que as empresas do tráfico de drogas internacional possam suportar, em média, uma perda de até $80 \%$ de seu produto sem que resultem deficitárias, graças aos seus altíssimos índices de lucratividade, artificialmente elevados e sustentados pelo war on drugs ${ }^{329}$.

A ocorrência do efeito hidra ${ }^{330}$, por sua vez, faz com que as operações aparentemente bem-sucedidas - e invariavelmente muito custosas - de combate à

\footnotetext{
${ }^{328}$ A esse respeito, manifesta-se Wisotsky: "Se a indústria da cocaína contratasse um consultor para criar um mecanismo voltado à garantia de sua lucratividade, não poderia ele fazer melhor do que a guerra às drogas: pressões bastantes para inflacionar preços, mas não o bastante para manter seu produto fora do mercado". WISOTSKY, S. Beyond the war on drugs: overcoming a failed public policy. Buffalo - New York: Prometheus Books, 1990, p. 36. Trad. livre.

${ }^{329}$ BERTRAM, Eva; BLACHMAN, Morris; SHARPE, Kenneth; ANDREAS, Peter. Op. cit., p. 15.

${ }^{330}$ Explicam Houaiss e Villar que a utilização figurativa do vocábulo hidra designa "fonte inesgotável de malefícios e destruição", e tem sua origem na mitologia grega: "h. de Lerna serpente cujas sete cabeças renasciam ao serem cortadas, destruída por Hércules”. HOUAISS, Antônio; VILLAR, Mauro de Salles. Dicionário Houaiss da língua portuguesa, 1ª reimpr. Rio de Janeiro: Objetiva, 2004, p. 1527.
} 
produção e distribuição de substâncias psicoativas, em vez de apresentarem os pretendidos resultados de redução das atividades ligadas ao tráfico, apenas acabam garantido novos mercados a outros atores. Isso porque a supressão de um grupo de negociadores que domina determinada fatia do mercado é acompanhada de sua substituição por outros grupos, seduzidos pelas altas lucratividades e pela pressão da demanda em relação à súbita escassez de oferta.

Assim sendo, vale lembrar, ilustrativamente, que, em 1989, o ocaso do assimchamado cartel de Medellín - reputado grupo dominante do tráfico internacional dos anos oitenta - representou, em um primeiro momento, decréscimo significativo da oferta da cocaína colombiana, mas, em pouco tempo, revelou-se apenas haver aberto espaço para a emergência de novos grupos, tendo-se recompostos os patamares perdidos de oferta em apenas seis mese ${ }^{331}$. Rapidamente, o cartel de Cali assumiria a posição de ator dominante do mercado, até que, em 1995, quando da derradeira ofensiva oficial contra essa agremiação, numerosos grupos de traficantes mais jovens e mais violentos prontamente ocuparam o espaço por ele deixado no mercado ${ }^{332}$. Fatos semelhantes já haviam ocorrido nos decênios anteriores: no início dos anos de 1970, quando pressões internacionais - sobretudo dos EUA, o maior mercado consumidor de quase todas as drogas - contra a produção turca de heroína contribuíram para o acelerado crescimento de sua produção em terras mexicanas, igualmente voltada para o abastecimento do mercado estadunidense $\mathrm{s}^{333}$; ao final da mesma década, pressões contra a produção mexicana de maconha desempenharam papel determinante na massificação de sua produção na Colômbia e nos próprios Estados Unidos ${ }^{334}$, hoje os maiores produtores mundiais da cannabis $^{335}$. De volta a meados da década de 1990, vale lembrar que ao declínio do cartel de Cali correspondeu não apenas o aparecimento de grupos de traficantes a ocuparem o espaço vazio da produção e distribuição colombiana, mas igualmente a dispersão da

\footnotetext{
${ }^{331}$ BERTRAM, Eva; BLACHMAN, Morris; SHARPE, Kenneth; ANDREAS, Peter. Op. cit., p. 19.

${ }^{332}$ Idem, ibidem, p. 19.

${ }^{333}$ Idem, ibidem, p. 19.

${ }^{334}$ Idem, ibidem, p. 19.

335 "Inside dope: the unstoppable economics of a booming process". In: Forbes. New York: Forbes, 28/10/2003, p. 146.
} 
produção de cocaína em outros países andinos como, especialmente, a Bolívia e o Peru $^{336}$.

Cumpre assinalar, não obstante, que a mesma lógica do efeito hidra se repete no combate às drogas verificado no varejo das grandes cidades: nelas, o estouro de determinados pontos de venda provoca a emergência de outros, assim como a neutralização de determinados grupos de comerciantes ilegais possibilita o aparecimento de outros a substituírem-nos e gozarem desse lucrativo negócio.

A ocorrência dos chamados paradoxo dos lucros e efeito hidra prestam-se evidentemente para minar de modo estrutural a eficácia das estratégias de guerra às drogas, e concorrem para reclamar soluções políticas diferentes desta que, com efeito, parece irremediavelmente fadada ao insucesso ${ }^{337}$.

\footnotetext{
${ }^{336}$ BERTRAM, Eva; BLACHMAN, Morris; SHARPE, Kenneth; ANDREAS, Peter. Op. cit., p. 19.

${ }^{337}$ Importa anotar, outrossim, que a constatação de que houve, nos últimos anos, uma sensível redução nos preços de psicoativos ao consumidor final nos mercados internacionais não vem a contestar as observações acima desenvolvidas; antes, mais parecem confirmá-la, pois denotam uma possível estabilização da demanda internacional por drogas ao passo que a oferta continua a crescer, certamente em virtude dos lucros sedutores (paradoxo dos lucros) e a despeito das contínuas interceptações dos órgãos de repressão oficial (efeito hidra). Ainda, é de se notar que as impressionantes margens de lucro forjadas pela repressão conferem grande elasticidade-preço à oferta de drogas, sendo que, ainda que a competição exija a sua deflação no varejo, o negócio continue sendo deveras atrativo economicamente (a respeito, vide supra, nota 120).
} 


\section{TENDÊNCIA ALTERNATIVA EMERGENTE: O ATUAL TRATAMENTO DA MATÉRIA NA EUROPA}

Antes de se analisar em separado diferentes políticas e legislações nacionais de países europeus acerca da matéria, cabe indagar, primeiramente, se, e em que medida, haveria uma política de controle de drogas comum em âmbito continental europeu ${ }^{338}$.

Isso porque, como se sabe, a despeito das muitas dificuldades inerentes a uma tal movimentação, há décadas o continente vem convergindo no sentido de uma ampla integração supranacional, que, se em seu início voltava-se fundamentalmente a questões de índole comercial, atualmente compreende também medidas legislativas e diretrizes políticas das mais diferentes ordens.

Essa análise adquire especial relevância à medida que, nas duas últimas décadas - desde que as políticas de redução de danos começaram a ser aceitas em diversos países -, a Europa vem gradualmente retomando parte da influência perdida para os EUA durante quase todo o século XX em matéria de formulação de políticas de controle de drogas. Em anos recentes, pode-se sentir uma maior presença européia em instâncias internacionais de particular relevo para a elaboração de políticas públicas concernentes, como é o caso da Comissão de Narcóticos das Nações Unidas $\left(C N D^{339}\right)$ e do Programa das Nações Unidas para o Controle de Drogas $\left(U N D C P^{340}\right)$, para cujo custeio as contribuições da União Européia têm aumentado de maneira notável $^{341}$.

\footnotetext{
338 No mesmo sentido, vide: RODRIGUES, Luciana Boiteux de Figueiredo. Controle penal sobre as drogas ilícitas: o impacto do proibicionismo no sistema penal e na sociedade. Tese de doutoramento apresentada à Faculdade de Direito da Universida de de São Paulo. São Paulo: 2006, p. 101.

339 Comission on Narcotic Drugs. Trata-se do principal órgão formulador de polític as atinentesa drogas no âmbito da ONU.

340 United Nations Intemational Drug Control Programme.

341 BOEKHOUTVAN SOLNGE, Tim. Drugs and decision-making in the European Union. Trad. Berveley J ackson. Amsterdam: Mets \& Sc hilt - CEDRO, 2002, p. 15. Segundo o autor, em 2002 a partic ipação da União Européia no orçamento do UNDCP atingira $70 \%$.
} 
Assim, já na Sessão Especial da Assembléia Geral das Nações Unidas $\left(U N G A S S^{342}\right)$ de 1998, pôde-se notar algum influxo da visão européia de atuação particular sobre a demanda - de que derivam as políticas de redução de danos como contraponto à tradicional abordagem repressiva ali prevalente, a qual foi historicamente influenciada pelas políticas da DEA norte-americana. Deste modo, verificou-se desde então a incorporação em sede multilateral da noção de que se deve trabalhar para reduzir os efeitos negativos do uso de drogas, algo que, efetivamente, identifica-se com aquelas políticas européias - malgrado o órgão internacional, tal como os EUA, obviasse a reprodução da expressão redução de danos ${ }^{343}$. O mesmo se diga quanto à consolidação, após a UNGASS, do princípio da responsabilidade compartilhada entre as nações acerca da oferta e da demanda por drogas, que significou uma relativização da idéia - igualmente assentada, década antes, pelos EUA - de que os países centrais eram vitimados pelos países periféricos responsáveis pela produção e oferta ${ }^{344}$.

Todavia, à atuação conjunta da União Européia nesse mister põem-se relevantes óbices. Em primeiro lugar, em meio às quase três dezenas de países que formam o bloco, evidentemente muitas são as divergências de políticas verificadas entre as preferidas de cada país, o que faz com que, por exemplo, idéias progressistas e liberalizantes que têm sido recentemente adotadas por países como Portugal, Itália e Espanha quedem-se opostas à doutrina repressiva predominante na Suécia e na França, vistos como os mais conservadores ${ }^{345}$. Ademais, não se pode olvidar

342 United Nations General Assembly Special Session.

343 Idem, ibidem, p. 15.

344 Idem, ibidem, p. 15. A emergência do princípio da responsabilidade compartilhada foi possibilitada, outrossim, pelo fato de o govemo Clinton haver ensaiado uma aproximação com líderes sul-americanos, a qual reclamava um disc urso menos intervenc ionista-milita rista que o de seus a ntecessores (RODRIGUES, Thiago. Política e drogas nas Américas. São paulo: Educ - Fapesp, 2004, p. 266). Adema is, a respeito das divergências polític o-crimina is verifica das no âmbito da UE, e com uma análise comparativa detalhada entre os casos opostos da Holanda, de um lado, e da França e Suécia, de outro, veja-se, do mesmo autor. Dealing with drugs in Europe - an investigation of European drug control experiences: France, The Netherlands and Sweden. Utrecht: Willem Pompe Institute for Criminal Law and Criminology, 2004, passim. Em sua a nálise, o autor constata que as notáveis diferenças de abordagem a presentada pelos países estuda dos têm menos relação com a natureza e intensidade de seus problemas socia is intemos com a questão das drogas que com as tradições histórico-cultura is-socia is que influem na política de cada nação.

345 BOEKHOUTVAN SO LNGE, Tim. Drugs and decision-making in the European Union. Tra d. Berveley J a ckson. Amsterda m: Mets \& Sc hilt - CEDRO, 2002, p. 16. 
princípio político-jurídico essencial das ordens democráticas, não raro consagrado constitucionalmente, segundo o qual somente compete ao Estado nacional legislar em matéria penal, o que impede uma legislação unificada supranacional - embora não impeça que diretrizes supranacionais influenciem, direta ou indiretamente, o âmbito jurídico interno dos Estados-partes ${ }^{346}$.

De toda sorte, constata-se ainda não ser possível falar-se em uma "política de drogas européia", mas apenas em "políticas de drogas européias" ${ }^{347}$, as quais, embora possam almejar uma integração futura ${ }^{348}$, ora esbarram em relevantes dificuldades políticas, jurídicas e culturais.

É possível, destarte, que a influência da União Européia sobre os entendimentos e políticas internacionais de controle de drogas venha a crescer no futuro, mas isso dependerá do grau de consenso e coesão que a generalidade

346 A respeito das implicações dos processos de integração sobre o direito penal intemo, tomando-se em consideração os específicos casos da União Européia e do Mercosul, vide: ESTEШTA, Heloísa. Integração regional e direito penal. Tese de doutoramento apresentada à Faculdade de Direito da Universidade de São Paulo, 2004, passim. Convém lembrar, outrossim, que, se uma legislação comunitária em matéria penal ainda não é possível, a cooperação policial e judicial em matéria penal constitui um dos três pila res sobre os qua is se assenta a integração européia (a respeito: LEWANDOWSKI, Enrique Ricardo. Globalização, regionalização e sobera nia. São Pa ulo: J ua rez de Oliveira, 2004, p. 188; BOEKHOUTVAN SO LNGE, Tim. Op. cit., p. 19-40), e que teóric os daquele continente já disc utem possibilidades de a tribuição futura de competência legislativa penal no âmbito da UE (DIAS, Augusto Silva. "De que direito penal precisamos nós europeus? Um olhar sobre algumas propostas recentes de constituição de um direito penal comunitánio". In: COSTA, J osé de Faria; SILVA, Marco A. Marques da. Direito penal especial, processo penal e direitos funda menta is: visã o luso-bra sileira. São Pa ulo: Qua rtier La tin, 2006, p. 337).

347 RODRIGUES, Luciana Boiteux de F. Controle penal sobre as drogas ilícitas: o impacto do proibicionismo no sistema penal e na sociedade. Tese de doutoramento apresentada à Faculdade de Direito da Universidade de São Paulo. São Paulo: 2006, p. 102. Tais políticas, entretanto não deixam de apresentar pontos de intersecção, como nos casos da quase unanimidade com que se aplica institucionalmente as polític as de redução de danos, bem como nos processos de despena lização - em diferentes graus - do mero usuá rio de drogas.

348 Anote-se também que, já nos primeiros a nos desta década, ministros de Estado da Justiça dos países membros da UE discutiram a efetiva unificação das polític as repressivas nac ionais no tocante ao tráfic 0 , o que abrangeria os modelos típic os do delito e o preceito secundário para cada modalidade - o tratamento da posse para consumo próprio e a classificação das substâncias controla das pemaneceria sob os critérios de cada país. A respeito: O Estado do Paraná (s.a.). “UE quer unificar penas e coordenar combate às drogas", 30/12/2003. Disponível em: বhttp://www.parana-online.com.br/editoria/mundo/news/69572/>. Acesso em: 15/01/2009. 
daqueles países consiga atingir previamente dentro do próprio bloco. Por ora, e ao menos por algum tempo, é certo que, embora hajam logrado integrar parte do tratamento da matéria e apresentem elevado grau de cooperação entre si para o cumprimento de suas diretrizes, remanescem essencialmente divididos na formulação e execução de políticas de prevenção e repressão ${ }^{349}$.

Por outro lado, há que se ter em conta que as limitações havidas no campo da elaboração legislativa em matéria penal não se aplicam a outras searas, sendo que, em matéria de saúde pública, a competência legislativa comunitária já é uma realidade - o que facilita, por exemplo, o planejamento de políticas em conjunto e a adoção de medidas comuns preventivas e de redução de danos ${ }^{350}$. A autonomia dos Estados nacionais para desenhar as suas próprias políticas em matéria de drogas é, deveras, cada vez menor ${ }^{351}$. O tema do controle de drogas inseriu-se na agenda de prioridades da União Européia já no ano do Tratado de Maastricht, em 1993, quando se instituiu o European Monitoring Centre for Drugs and Drug Addiction $(E M C D D A)^{352}$, sediado em Lisboa, com o fito de coordenar e avaliar estratégias e planos de ações comunitários plurianuais ${ }^{353}$ e de reunir informações e estudos sobre as políticas de cada país em matéria de drogas, com o que contribui igualmente na elaboração de políticas nacionais respeitantes. Não obstante, a avaliação das estratégias nacionais relacionadas às drogas constitui parte do processo de análise da candidatura de novos países à admissão no bloco ${ }^{354}$.

Demonstrando a visão mais liberal da União Européia em relação à abordagem hegemônica da autoridade internacional, o próprio Parlamento Europeu,

349 BOEKHOUTVAN SOUNGE, Tim. Op. cit., p. 16.

350 RODRIGUES, Luciana Boiteux de F. Op. cit., p. 102.

351 BOEKHOUTVAN SOLNGE, Tim. Op. cit., p. 16.

$352 \mathrm{Ou}$, na tradução oficial para o português, Observatório Europeu da Droga e da Toxic odependência (OEDT).

353 A estratégia estabelecida pelo Conselho da UE para os anos de 2005 a 2012, bem como os planos de ação quadrienais do peńodo, enc ontram-se disponíveis no website do

EMCDDA:

বhttp:// www.emc dda.europa.eu/html.c fm/index6790EN.html>.

354 Desta forma, O EMCDDA monitora igualmente as concementes estratégias nacionais de países membros e de países candidatos, disponibilizando as respectivas informações em seu website: বhttp://www.emcdda.europa.eu/html.cfm/index1360EN.html>. 
que já testemunhou proposições extremamente progressistas ${ }^{355}$ - embora, imanentemente sujeito a alterações políticas em sua composição, nem sempre haja mantido uma coerência em suas compreensões a respeito -, manifestou de forma oficial a necessidade de se oferecer a toxicômanos "programas de cunho sanitário e social que não podem correr o risco de serem obstaculizados pela repressão" $" 356$. A seu turno, refletindo a atual tendência liberal européia, o Conselho da União Européia $^{357}$ recomenda de forma explícita a criminalização da posse de drogas somente se constatada a intenção de tráfico ${ }^{358}$ - ainda que contenha a ressalva, como é próprio de documentos legais internacionais, de os Estados nacionais poderem entender por uma legislação interna mais rígida ${ }^{359} 360$.

O tema também se vê incluído na política externa comunitária, na medida em que a adoção de determinadas ações de controle de drogas podem constituir um pré-requisito para acordos de cooperação com a UE ${ }^{361}$.

355 O Relatório D'Anconna, ali debatido em 1998 a propósito da UNGASS, propôs originalmente a adoção comum de medidas como a descriminalização da cannabis, a administração de heroína a dependentes e a recomendação para reforma das convenções intemaciona is da ONU; a pós um sucesso inic ial a tribuído à abstenção de conservadores dos debates, acabou desfigurado por emendas que forçaram um recuo da relatora (a respeito, vide: BOEKHOUT VAN SOLNGE, Tim. Op. cit., p. 62-63). De peculiar importância por sua atualidade, o Relatório Buitenweg, votado a os 02 de dezembro de 2008, a lude em seu parágrafo 149 a que se garanta a dependentes pleno acesso a serviçoos de tratamento, e a que não se tratem cidadãos como criminosos pelo único motivo de consumirem psicoativos ilícitos (disponível em: বhttp://www.europarl.europa .eu/sides/getDoc.do? type =REPORT\&mode =XML\&refer ence $=A 6-2008-0479 \&$ language $=E N \#$ title $3>$. Acesso em: 15/01/2009.

356 Resolution la lutte contre le drogue, nov/1995 - renovada em 1998. Apud RODRIGUES, Luciana Boiteux de F. Op. cit., p. 103.

357 Reunião dos chefes de Estado naciona is.

358 Decisão-quadro 2004/757/J HA, art. 2, 1, "c". Referido texto legal estabelece elementos mínimos constitutivos do delito de tráfico de entorpecentes para serem adotados nas legislações intemas dos países membros, bem como orientações para o sancionamento penal do tráfico - incluindo, vale mencionar, a sugestão de responsa bilizaçã o criminal da pessoa juŕdic a para quando o fato seja cometido em seu benefício (preâmbulo, parágrafo 8). Disponível em: বhttp:// eldd .emc dda.europa.eu/html.c fm/ind ex5173EN.html? plug inMethod=eldd.sh owlegaltextdetail\&id=3161\&lang=en\&T=2>. Acesso em: 15/01/2009.

359 Preâmbulo, parágrafo 4.

360 Importa ainda lembrar que os órgãos decisórios e de formulação e recomendação de políticas e diretrizes no seio da UE são muitos, razão por que assuntos relacionados a drogas acabam por ser discutidos em diversos deles - 0 que, mais uma vez, demonstra a importância ali adquirida pelo tema.

361 BOEKHOUTVAN SOLNGE, Tim. Op. cit., p. 08. 
No tocante a pontos de intersecção observados entre as diferentes políticas internas dos países membros, ressaltam-se, desde logo, a quase unanimidade com que se aplica institucionalmente as políticas de redução de danos ${ }^{362}$, bem como os processos e tendências de despenalização ou descriminalização da conduta do mero usuário ${ }^{363}$. Há ainda, em geral, a tendência à diferenciação da resposta dependentemente do tipo de droga envolvido em cada caso concreto ${ }^{364}$, pelo que especialmente a cannabis é merecedora de tratamento mais brando, muitas vezes com autorizações para uso terapêutico ${ }^{365}$ e até mesmo para pequena produção doméstica voltada ao consumo pessoal ${ }^{366}$. De outra parte, o tratamento dispensado ao comércio de psicoativos ilícitos diferencia, em muitos casos, o agente que vende à droga com o fim de sustentar seu vício daquele meramente movido pelo lucro ${ }^{367}$, sujeitando-se ambos, igualmente, às diferenciações decorrentes da natureza "leve" ou "pesada" da droga correspondente ${ }^{368}$.

Estas, em linhas gerais, as similaridades verificadas nas diferentes políticas legislativas adotadas pelos Estados europeus, dentre os quais, ora, escolhem-se alguns $^{369}$ para análise individualizada ${ }^{370} 371$.

362 Idem, ibidem, p. 15.

363 Rodrigues aponta que, a lém da descrimina lização recentemente operada por Espanha, Itália e Portugal (e do caso da Holanda, já mais antigo), também países como Alemanha, Áustria, Bélgica, Dinamarca, Irlanda, Reino Unido e Suíça houveram por despenalizar a conduta do usuário. RODRIGUES, Luciana Boiteux de F. Controle penal sobre as drogas ilícitas: o impacto do proibicionismo no sistema penal e na sociedade. Tese de doutoramento apresentada à Faculdade de Direito da Universida de de São Paulo. São Paulo: 2006, p. 103.

364 Casos da Áustria, Bélgica, Dinamarca, Espanha, Holanda, Irlanda, Itália, Luxemburgo, Reino Unido e Portugal. Idem, ibidem, p. 104.

365 Ca sos da Alemanha, Bélgica, Espanha e Reino Unido. Idem, ibidem, p. 104.

366 Caso da Holanda.

367 RODRIG UES, Luciana Boiteux de F. Op. cit., p. 106.

368 Cabe anotar que tais diferenciações, geralmente válidas tanto para usuários quanto para comerciantes, são, no mais das vezes, observadas pelos textos legisla tivos de diferentes países, mas, outras vezes em que não o são, acabam por se tomar praxe jurisprudencial - como os casos da Alemanha e da Suíça. Idem, ibidem., p. 104.

369 Os critérios para tal escolha - arbitrária, de certo modo - repousam a princípio na circunstância de, a nosso ver, os eleitos parecerem deter, dada a sua proeminência política e/ou tradição jurídica, maior potencial de influenciar outros sistemas legislativos. Não obstante, também se considerou como critério deteminante a circunstância de tais países apresentarem, em maior ou menor medida, algum viés altemativo à hegemonia do proibicionismo - eis a razão principal da exclusão da França (que, de resto, a despeito de sua tradição em direito público - constitucional, administrativo e sancionador-pouco influencia a 


\subsection{Alemanha}

A República Federal da Alemanha adotou, em junho de 2003, o Plano de Ação sobre Drogas e Adição ${ }^{372}$, que abrange quatro principais focos: (i) prevenção do uso; (ii) aconselhamento, tratamento e reabilitação; (iii) auxílio à sobrevivência e redução de danos; (iv) repressão e redução da oferta ${ }^{373}$. Alude à drogadição sob uma manifesta perspectiva política de saúde pública ${ }^{374}$, e, demais de visar apenas às relações diretas com drogas ilícitas, volta sua atenção igualmente a outros grupos determinados como filhos de usuários, grupos de risco, usuários de outras substâncias assemelhadas, condutores de veículos.

Referida política substituiu o anterior Plano para o Combate de Drogas, datado de 1990, e, como evidenciado por seus próprios nomes, significou uma mudança de política no sentido de uma perspectiva menos agressiva e mais realista e objetiva, em consonância com a supra-referida evolução da compreensão européia acerca da matéria - portanto, menos influenciada, em certa medida, pela abordagem belicista dos EUA e das Nações Unidas.

teoria e legislação penal de outros países), cuja abordagem repressiva, como já aludido, destoa da maioria dospaíses da UE.

370 Cumpre esclarecer que o estudo doravante apresentado não almeja aprofundar-se em classificações dogmáticas sobre normas de diferentes países e culturas jurídicas - o que, de resto, seria impossível dentro dos limites deste traba lho -, mas, fundamentalmente: (i) apresentar a maneira como suas instituições e agências de controle respondem a problemas - de natureza penal ou não derivados das relações entre drogas e cidadãos; e (ii) colaborar na busca de altemativas a o pensamento proibic ionista que, se aos poucos parece perder parte de sua influência sobre países europeus ocidentais, a inda reina com tranqüilidade em todo o continente americano, e influencia sobremaneira - e, a nosso ver, negativa mente - a política criminal bra sileira.

371 Esclareça-se, outrossim, que as análises de textos legislativos doravante procedidas utilizaram como fonte, em regra geral, o European legal database on drugs, disponível no website do EMCDDA.

372 Germany. Federal Ministry of Health and Social Sec unity. Action Plan on Drugs and Addiction. Disponível em: বhttp:// www.emc dda.europa.eu/attachements.cfm/att_35452_EN_Gemany\%20Ac tion\%20plan\%202003-\%20Englisch.pdf>. Acesso em: 15/01/2009.

373 lbidem, cfr. p. 3; 15-16. Acesso em: 15/01/2009

374 Ibidem, p. 13-15. Acesso em: 15/01/2009 
No que toca especificamente ao tratamento legal e penal, o plano dispõe que previsões e revisões legislativas devem ser feitas à luz das convenções internacionais e normas comunitárias vigentes, e conforme se entenda necessário ${ }^{375}$.

De acordo com o direito alemão ${ }^{376}$, o consumo pessoal de psicoativos não é tratado como delito em sentido estrito. Contudo, a posse para consumo próprio, quando desprovida de autorização escrita para a sua aquisição, constitui ofensa nos termos do art. 29, § 1 da Lei de Narcóticos de 1981. Há, após uma emenda de 1992, um considerável espaço de discricionariedade administrativa quanto à persecução, na medida em que o promotor de justiça pode abster-se de prosseguir com qualquer procedimento criminal se, tratando-se de quantidade pequena de droga inequivocamente para uso próprio - considerar limitadas a reprovabilidade da conduta e o interesse público que dela derive; neste caso, mesmo a eventual opinião da autoridade judicial em contrário - ou seja, favorável à persecução - não há que ser levada em consideração (art. 31a) ${ }^{377}$.

Tendo analisado a ofensa de consumo pessoal em 1994, o Tribunal Constitucional Federal alemão declarou a constitucionalidade de sua incriminação ${ }^{378}$ bem como da reserva de discricionariedade supracitadas, entendendo estarem observados os princípios da proporcionalidade, igualdade e liberdade individual. Observou, porém, que autoridades administrativas e judiciais devem cuidar para (i) que o disposto no art. 31a seja plenamente aplicado; (ii) que o tratamento jurídico nos casos concretos seja isonômico; (iii) que, especialmente em casos de posse para

375 lbidem, p. 39-41.

376 A Lei de Drogas alemã foi consultada em língua inglesa, de acordo com a tradução oficial realizada pelo Ministério da Saúde e Seguridade Social local, e encontra-se disponível em: বhttp:// eldd .emc dda.europa.eu/html.c fm/index5173EN.html? plug inMethod=eldd.sh owleg altextdeta il\&id $=677 \&$ lang =en\&T=2\#C $1>$. Acesso em 15/01/2009.

377 Toda via, a contrario sensu, é dada à s cortes a possibilidade de, entendendo não haver interesse públic o na continuidade da persecução, a rquivar o feito no estado em que se encontre. BÖШNGER, Lorenz. "Symbolic Criminal Law without limits". Disponível em: বhttp://www.drugtext.org/library/articles/94-const.html>. Acesso em: $15 / 01 / 2009$.

$378 \mathrm{~A}$ a firmação da constitucionalida de de um modelo incriminador desprovido de lesivida de substancial foi critic a da por Böllinger, que condenou a utilização de uma política criminal baseada no simbolismo no afã de se tentar resolver problemas socia is. BÖШNGER, Lorenz. "Symbolic Criminal Law without limits". Disponível em: বhttp://www.drugtext.org/library/artic les/94-const.html>. Acesso em: 15/01/2009. 
uso próprio de pequenas quantidades de cannabis, atentasse-se ao princípio geral de prevenção de punições excessivas $^{379}$.

As substâncias de uso controlado no país figuram taxativamente em três listas referidas pelo art. 1 da Lei de Narcóticos, as quais compreendem todas as substâncias arroladas pelas convenções da ONU, além de algumas outras mencionadas por decisões normativas da UE ou pelo governo alemão ali classificadas como estupefacientes. Agrupam-se nas listas segundo a sua prescritibilidade potencial para fins medicinais e implicações de menor ou maior controle $^{380}$. Alterações nas listas podem ser feitas através de ordens da administração federal que, com o consentimento do Senado, adquirem força de lei (art. 1, § 2); não obstante, em caso de risco urgente à saúde pública derivado do uso indevido de determinada substância, mesmo à falta de consentimento do Senado pode o Ministro da Saúde inseri-la no rol por um período de um ano (art. 1, § 3).

Todas as infrações, sanções e disposições correlatas são previstas entre os arts. 29 e 34 da lei alemã, que as distribui, em regra, em quatro categorias: (i) ofensas criminais ordinárias, puníveis com até cinco anos (sem limite mínimo) de prisão ou multa nos termos do art. $29, \S 1$, itens 1 a 14 ; (ii) ofensas criminais de maior gravidade, puníveis com prisão de um a quinze anos nos termos dos arts. $29, \S$ 3 et 29a; (iii) crimes, puníveis com prisão de dois (em certos casos, três ou cinco) a quinze anos nos termos dos arts. 30 usque 30b; (iv) infrações administrativas,

379 European Union. EMCDDA. European Legal Database on Drugs. Contry profile: Germany. Disponível em: বhttp://eldd.emcdda.europa.eu/html.cfm/index5174EN.html\#B6>. Acesso em: 15/01/2009. A esse respeito, o atual Plano de Ação previu a realização de um estudo empírico sobre a aplicação prática do art. 31a em todo o país, a fim de avaliar a sua desejada uniformidade conforme a determinação do Tribunal Constitucional. Isso porque, conquanto se soubesse, desde outro estudo empírico rea liza do em 1997, que, em se tratando de cannabis, a opção dos promotores pela não persecução em casos de posse de até $10 \mathrm{~g}$ da droga fosse praticamente unânime, ainda remanesciam divergências sobre o significado de "pequenas quantidades" entre as onientações dos órgãos de persecução de diferentes regiões do país. Não obstante, previu o Plano de Ação a realização de outra pesquisa empírica, com o fito de verificar o impacto preventivo-especial nas pessoas até então afetadas pela aplicação do art. 31a. Gemany. Federal Ministry of Health and Social Security. Action Plan on Drugs and Addiction, p. 42. Disponível em: বhttp://www.emcdda.europa.eu/atta chements.cfm/att_35452_EN_Germa ny\%20Ac tion\%20plan\%202003-\%20Englisch.pdf>. Acesso em: 15/01/2009 380 European Union. EMCDDA. European Legal Database on Drugs. Ibidem. Acesso em: 15/01/2009. 
sujeitas apenas a multas (naturalmente, de caráter administrativo) nos termos do art. 32. A produção, cultivo, distribuição e comercialização de substâncias proibidas, como condutas análogas ao tráfico, inserem-se entre as merecedoras de respostas mais graves, em especial quando envolvam quantidades "não insignificantes" de droga; porém, a sua classificação entre aquelas categorias, e, por conseguinte, a sanção a ser aplicada varia de acordo com a concretude de cada caso, conforme podem subsumir-se a uma ou mais circunstâncias explicitamente previstas na lei. São estas, entre outras, a comercialização de substância proibida para menor de 18 anos (art. 29a, §1,1), a inserção de menor no tráfico (art. 30a, §2, 1), a criação de risco para diversas pessoas (art. 29, § 3,2), a adesão ao tráfico ilícito na forma de atividade comercial (art. 30, §1,2) ou como parte de um bando (art. 30, §1, 1), o emprego de arma no cometimento da ofensa ou delito relacionado à droga (art. 30 a , $\S 2,2)$.

Ainda, cabe observar que os estatutos legais de crimes e ofensas acima referidos aplicam-se igualmente a quaisquer substâncias listadas, independentemente de seu tipo e classificação. Porém, no momento de imposição de eventual sanção, a autoridade judicial necessariamente haverá que considerar, além da quantidade, a periculosidade da substância e o grau de criação de riscos não permitidos envolvidos na conduta em apreço.

Em face da consagração da abordagem de saúde pública na política de drogas alemã, modificações graduais em sua legislação pretenderam estimular o tratamento em lugar da mera sanção. Assim é que, embora não se diferenciem expressamente as figuras típicas do traficante-usuário e do traficante-empreendedor, a possibilidade de suspender a execução da sanção privativa da liberdade alcança plenamente aquele, caso assim escolha (art. 35). O programa de "terapia em vez de pena", vigente desde 1982, é referido pela política oficial alemã como de comprovado sucesso $^{381}$, embora o adiamento e suspensão da pena nos termos do art.

381 Neste sentido, aceita-se não a penas a suspensão da execução da pena em seu iníc io, como também a sua intemupção quando o apenado deseje submeter-se a tratamento.Gemany. Federal Ministry of Health. Action Plan on Drugs and Addiction, $\quad$ p. 42. Disponível em: বhttp://www.emcdda.europa.eu/atta chements.cfm/att_35452_EN_Germany\%20Ac tion\%20plan\%202003-\%20Englisch.pdf>. Acesso em: 15/01/2009 
35 apresentem elevado grau de revogação em casos $\operatorname{concretos}^{382}$. A legislação alemã também estabelece critérios de registro e regulação de terapias médicas de substituição, bem como regras mínimas para a existência de narco-salas ${ }^{383}$ - cuja regulamentação é complementada pela autoridade executiva federal ${ }^{384}$.

Por fim, cite-se que, devido a emendas aprovadas desde meados da década de 1990, permite-se o cultivo de cannabis para fins comerciais lícitos atendendo-se a alguns pressupostos e limitações, como a necessidade de especial registro, a submissão a fiscalização permanente e a concentração máxima de $0,3 \%$ de THC (art. 19, §3) $)^{385}$.

Como se nota, a política criminal alemã contempla um modelo despenalizador para com a conduta do usuário, ao qual se põe uma abordagem, muita vez, mais voltada à perspectiva da saúde pública que à da repressão penal. Nesse mister, é de se ver que, conquanto haja norma proibitiva de natureza penal a tutelar a posse para uso próprio, subsistem mecanismos legais para que o órgão responsável pela persecução decline do processamento de muitos casos menores - ou se ele não o fizer, para que a própria autoridade judicial o faça.

Outrossim, a decisão de 1994 do Tribunal Constitucional, se por um lado merece críticas pela admissão da constitucionalidade de condutas desprovidas de antijuridicidade material, por outro acertou em estabelecer limites rígidos à

382 O Plano de Ação deteminou a realização de estudos empíicos para investigar as razões dessa a lta incidência de revogaçõese, se o caso, modific ar a legislação. lbidem, p. 42.

383 As narco-salas na Alemanha são reguladas pela legislação federal e oferecidas por municipalidades que optem por fazê-lo. De acordo com o Plano de Ação tedesco, resultados iniciais de avaliações em todo o país indicam sucesso no propósito de alcançar grupos de heroinômanos raramente acessíveis a outras políticas, importando em contribuição para a redução de danos à saúde pública. Germany. Federal Ministry of Health and Social Security. Action Plan on Drugs and Addiction, $\quad$ p. $38 . \quad$ Disponível em: http://www.emcdda.europa.eu/attachements.cfm/att_35452_EN_Germany\%20Acti on\%20plan\%202003-\%20Englisch.pdf. Acesso em: 15/01/2009.

384 European Union. EMCDDA. European Legal Database on Drugs. Contry profile: Gemany. Disponível em: বhttp://eldd.emc dda.europa.eu/html.cfm/index5174EN.html\#B6>. Acesso em: $15 / 01 / 2009$.

385 lbidem. Acesso em: 15/01/2009. 
criminalização secundária do usuário - logrando conferir-lhe maior segurança jurídica - e em ressaltar a necessidade de não se punirem fatos insignificantes.

Demais da imperiosa necessidade de descriminalizar a posse para uso próprio, parece faltar à legislação tedesca, igualmente, uma diferenciação legal entre as condutas de traficar para sustentar o próprio consumo e traficar com intuito de obtenção de lucro, porquanto ambas apresentam reprovabilidade diversa.

Em face do contexto internacional repressivo, todavia, é certo que a instituição de medidas - legislativas ou executivas - despenalizadoras e a objetividade com que o país vem empregando, com sucesso, programas preventivos e de redução de danos, denotam que o país se situa entre os avançados no campo de políticas públicas de controle de drogas.

\subsection{Espanha}

A Espanha adotou na virada do século a sua Estratégia Nacional de Drogas 2000-2008, cujos objetivos gerais foram agrupados em três principais áreas de intervenção: redução da demanda, redução da oferta e cooperação internacional $^{386}$. desenvolvimento regulatório, pesquisas e treinamentos e sistemas de informação e avaliação. Após um estudo de sua evolução realizado em 2004, foi complementada no ano seguinte pela instituição de um Plano de Ação quadrienal (2005-2008), que definiu foco em seis eixos de trabalho: coordenação, prevenção e sensibilização social, assistência integral, ampliação do conhecimento respeitante, redução da oferta e cooperação internacional ${ }^{387}$.

O país divide-se em dezessete comunidades autônomas, que possuem competência legislativa e executiva em campos como saúde, higiene e assistência social (conforme art. 148.1, §§ 20 e 21 da Constituição espanhola). Medidas

386 Spa in. Ministry of Interior. National Drugs Strategy 2000-2008, p. 41. Disponível em:

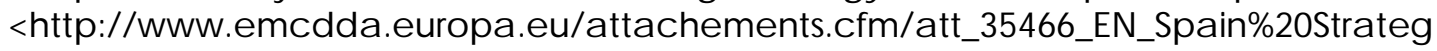
y\%202000-2008\%20English.pdf>. Acesso em: 15/01/2009.

387 España. Ministerio de Sanidad y Consumo. Plan de Acción 2005-2008, p. 19. Disponível em: বhttp://www.emc dda.europa.eu/attachements.cfm/att_35464_ES_Spain\%20Action \%20Plan\%202005-2008\%20Spanish.pdf>. Ac esso em: 15/01/2009. 
preventivas e de tratamento de usuários, portanto, diferem de uma a outra comunidade, embora todas devam seguir as orientações postas pelos supracitados Estratégia Nacional e Plano de Ação, que concentram foco como na busca de detecção precoce de fatores de risco $^{388}$, no tratamento precoce ${ }^{389}$, na reintegração social e laboral $^{390}$ e na assistência às famílias de toxicômanos ${ }^{391}$. Ademais, a exemplo da experiência alemã, a realização de políticas de redução de danos merecem especial atenção das autoridades e sociedade espanhola, havendo ali bemsucedidos programas de trocas de seringas - inclusive no interior de estabelecimentos penitenciários -, testes de qualidade de comprimidos em festas raves, terapias de substituição ${ }^{392}$ e disponibilização de narco-salas para consumo seguro $^{393}$.

Conquanto haja sido, ao lado do Chipre, o primeiro país de todo o mundo a ratificar a Convenção de Viena de 1988 394 , somente em 1992 a Espanha veio a regular, propriamente, a posse e o consumo pessoal de drogas (Lei Orgânica $1 / 1992)^{395}$.

\footnotetext{
$388 \mathrm{lbidem}$, p. 28.

$389 \mathrm{lb}$ idem, p. 28.

$390 \mathrm{lb}$ idem, p. 33.

$391 \mathrm{lbidem}, \mathrm{p} .30$.

392 RODRIGUES, Luciana Boiteux de F. Controle penal sobre as drogas ilícitas: o impacto do proibicionismo no sistema penal e na sociedade. Tese de doutoramento apresentada à Faculdade de Direito da Universidade de São Paulo. São Paulo: 2006, p. 115.

393 Ibidem, p. 31-33. A respeito, vale acrescentar que, em 2000, a Espanha optou por regulamentar a existência de narco-salas, a exemplo do que sucedera primeiramente na Suíça, em 1986, e depois na Holanda e na Alemanha, no início dos anos 90. Consoante relatório coordenado pelo EMCDDA, esses são os quatro países europeus que as adotam até o presente momento (em um total de 72 cidades), sendo que Luxemburgo e Noruega devem oferecê-las em breve - o que demonstra uma certa tendência de ampliação e um possível reconhecimento de sucesso da política. European Union. EMCDDA. European report on drug consumption rooms - Executive Summary. Disponível em: $\Varangle$ ttp:// www.emc dda.europa .eu/index.c fm? fusea ction=public.Atta chmentDownlo a d\&nNodeID=2943\&slanguageISO =EN >. Acesso em: 15/01/2009.

394 ESCOHOTADO, Antonio. Historia general de las drogas, 3a ed. Madrid: Espasa, 2000, p. 1124.

395 A Lei 17/1967 considerou ilegal o consumo e posse de drogas, ainda que para finalidades medicinais; entretanto, não previu qualquer conseqüência sancionatória. Entre 1971 e 1983, o art. 344 do Código Penal visava a abranger, a lém do tráfico e condutas a nálogas, ta mbém o consumo de psicoativos, embora dedicasse-lhes sanções idênticas, desrespeitando flagrantemente o princípio da proporcionalidade; não obstante, a legislação franquista apresentava cláusulas abertas que violavam, igualmente, os princípios da tipicidade e legalidade estrita.
} 
Referido diploma, todavia, dedicou sanções meramente administrativas às condutas do usuário de drogas, as quais, mesmo após a reforma global do Código Penal de 1995, permaneceram descriminalizadas. Assim sendo, a legislação espanhola apenas proíbe a posse e o consumo de drogas em locais públicos, nos termos da Lei Orgânica 1/1992 (art. 25, 1), impondo-lhes multas que podem variar de $€ 300$ a $€$ 30000. É possível haver, ademais, a suspensão da execução da multa administrativa caso o infrator submeta-se voluntariamente a programa oficial de tratamento a drogaditos, (art. 25, 2 da mesma lei, regulamentado pelo Decreto Real 1079/1993).

Visto inexistirem no direito espanhol listas específicas de drogas controladas, faz-se referência direta às normas que internalizaram no ordenamento a Convenção Única sobre Entorpecentes de 1961 e a Convenção sobre Drogas Psicotrópicas de $1971^{396}$, bem como a outras normas locais que lhes adicionam substâncias a serem controladas.

No que toca ao tráfico e condutas análogas, sem embargo, a legislação do país é uma das mais severas do continente ${ }^{397}$. As penas ordinárias para tais delitos, insculpidos nos arts. 368 a 378 do Código Penal, são, em via de regra, de três a nove anos de prisão quando envolvam "substâncias ou produtos que causem graves danos à saúde" (art 368) e de um a três anos "nos demais casos" (art. 368) ${ }^{398}$,

Reforma de 1983 excluiu do Código Penal condutas atinentes ao usuário, que já eram, dadas as incoerências dogmáticas, inaplicadas segundo jurisprudência pacífic a no país. A respeito: Idem, ibidem, p. 1106; DE LA CUESTA ARZAMENDI, J osé Luis. "La Política criminal en materia de drogas en España, tras el nuevo Código Penal". In: Cuademos de derecho Judicial. Política criminal comparada, hoy y mañana. Madrid: CGPG, 1999, p. 88.

396 Respectivamente, art. 2 da Lei 17/1967 e art. 1 do Dec reto Real 2829/1977.

397 Deveras, nesse particular, a tutela de drogas constituiu uma exc eção ao ideal progressista do novo Código Penal espanhol de 1995, a o manter um “puro e simples continuísmo" da tutela desmesura damente repressiva a li estabelecida em $1988 \mathrm{em}$ face de pressões intemacionais. DE LA CUESTA ARZAMENDI, José Luis. Op. cit., p. 88 et seq.

398 Observe-se que, com tal diferenciação, o legislador espanhol visou a estabelecer alguma proporcionalida de na resposta punitiva de acordo com o grau de periculosidade da substância cultivada, elaborada, traficada ou cujo consumo foi haja sido de qualquer modo promovido, favorecido ou facilitado pelo agente. Impõe-se-lhe, porém, a dificuldade de se estabelecer com segurança quais seriam as substâncias subsumíveis às sanções mais severas e qua is as merecedoras das sanções menos severas, sobretudo considerando-se a ausência de referência a uma classific ação qua lquer - embora se saiba, por exemplo, que a heroína ou a cocaína certamente figurariam na primeira. Outra dificuldade à legitimidade da 
somadas a multas de, respectivamente, até três e duas vezes o valor da mercadoria. Adicionalmente à primeira hipótese, pode implicar uma exasperação da pena até o limite de vinte anos e três meses de prisão e multa de até o quádruplo do valor da mercadoria a incidência de agravantes como: (i) a introdução de drogas em escolas ou instituições penitenciárias ou militares - art. 369, $1^{\text {o }}$; (ii) a venda a menores de 18 anos - art. 369, $1^{\circ}$; (iii) a venda em estabelecimento aberto ao público realizada por proprietário ou funcionário deste - art. 369, 2º; (iv) a afetação de grandes quantidades de droga na conduta - art. $369,3^{\circ}$; (v) o oferecimento de drogas a pessoas em tratamento (art. 369, $4^{\circ}$ ); (vi) a adulteração da pureza do psicoativo e conseguinte incremento de nocividade - art. 369, $5^{\circ}$; (vii) o pertencimento do agente a associação, ainda que transitória e ocasional, que tenha como finalidade a difusão das substâncias - art. 369, 6\% ; (viii) o agente participar de outras atividades delitivas organizadas ou cuja execução se facilite com o cometimento do delito - art. 369, $7^{\circ}$; (ix) a venda praticada por autoridade, funcionário público, trabalhador social ou educador servindo-se de sua função - art. 369, 8º (x) e a inserção de menores de 16 anos no tráfico - art. $369,9^{\circ}$.

O Código Penal espanhol também considera crime contra a saúde pública a produção, circulação e comercialização sem autorização e controle de substâncias precursoras, punível com sanções de entre três e seis anos de privação da liberdade (art. 371).

Na parte geral do código, juntamente com a previsão da embriaguez acidental, há também a previsão da intoxicação acidental como excludente de responsabilidade (art. 20, § 2). Situações em que dependentes cometem crimes contra o patrimônio com o escopo de, mediante o valor aproveitado, sustentar seu vício, quando hajam sido cometidos com o agente sob efeito do uso de drogas ou de crise de abstinência, podem implicar a que o juiz, ao fim do processo, declare impunível o fato e ordene aquele a submeter-se a tratamento residencial. Em casos outros, é

incriminação advém do fato de a figura típica ser de periculosidade abstrata, pelo que resulta questionável a incriminação, a pretexto de tutela da saúde pública, de uma conduta de cultivo ou comércio de substância que não cause grave dano à saúde individual ou coletiva - hipótese da parte final da descrição típica. Isso porque, como instrumento de tutela subsidiária de bens jurídicos, o direito penal deve cuidar apenas de lesões particulamente relevantes à manutenção da coexistência humana e convivência social, e não de lesões potenciais presumidas e singelas. 
possível aplicar-se, preenchidos determinados requisitos legalmente estabelecidos, atenuante genérica de dependência grave (art. 21, § 2). Por derradeiro, nos casos em que a pena aplicada seja igual ou menor de três anos de prisão, sua execução pode ser suspensa, reduzida ou substituída se o apenado se submeter voluntariamente a tratamento; eventual abandono do tratamento ou cometimento de novo delito durante o espaço temporal a ele atinente - que pode variar entre três e cinco anos - acarretará a sua revogação (art. 81, 1, 3 et 4).

Não há, entretanto, previsões legais de circunstâncias atenuantes para casos de tráfico e condutas análogas em que o agente os pratique com o fim de financiar seu vício.

Em virtude de o país haver promovido uma reforma global em seu Código Penal na metade da década passada, a legislação espanhola, dentre as analisadas, é a que se encontra mais bem organizada e sistematizada. É digna de aplausos, ademais, por não impor ao usuário as consequiências restritivas e altamente estigmatizantes que resultam da tutela penal, permitindo-se oferecer-lhe programas preventivos e terapêuticos mais amplos e eficazes.

A previsão de hipótese de exclusão de responsabilidade consubstanciada na intoxicação acidental é igualmente positiva, porquanto não haveria motivos para tratá-la diversamente do tratamento dispensado à embriaguez inscrita no mesmo art. 20, § 2.do Código Penal (parte geral).

É de se lamentar, entretanto, a desatenção do legislador de 1995 para com a proporcionalidade das penas tocantes ao tráfico e condutas análogas, visto que pouco fez senão perenizar tendências de uma legislação repressiva aprovada em 1988 sob forte influência de campanhas mediáticas ${ }^{399}$ e de pressões internacionais ao tempo da Convenção de Viena ${ }^{400}$ - prontamente ratificada pelo país. Lamenta-se, outrossim, e também no caso espanhol, a ausência de diferenciação legal entre

399 ESCOHOTADO, Antonio. Historia general de las drogas, 3a ed. Madrid: Espasa, 2000, p. 1103-1110.

400 DE LA CUESTA ARZAMENDI, J osé Luis. “La Política criminal en materia de drogas en España, tras el nuevo Código Penal". In: Cuademos de derecho J udicial. Política c riminal compara da, hoy y mañana. Madrid: CG PG, 1999, p. 88. 
condutas que mereceriam tratamento diverso: o tráfico para fins comerciais e o tráfico para exclusivo financiamento do consumo de drogas.

\subsection{Holanda}

Os princípios básicos da política de drogas holandesa, a distinção entre drogas leves e drogas pesadas e a abordagem integrada e equilibrada do tema, vêm estabelecidos no documento intitulado Política de Drogas: Continuidade e Mudanças, datado de 1995. Nele, em cujo âmbito se incluem somente as drogas consideradas ilícitas no país, estabeleceram-se quatro objetivos nucleares: (i) prevenção do uso, tratamento e reabilitação de usuários; (ii) redução de danos a usuários; (iii) redução de incômodos públicos causados por usuários ("public nuisance"); (iv) combate à produção e tráfico de drogas. Esse planejamento global vem sendo complementado, com o passar do tempo, por diversas outras estratégias políticas, no mais das vezes voltadas a fins mais específicos, como os casos do combate à produção e tráfico de ecstasy (datada de 2001), da cocaína (de 2002) e, inclusive, da cannabis (de 2004).

O governo central atribui grande ênfase a políticas de prevenção; as escolas devem obrigatoriamente oferecer, desde a educação primária, programas de promoção de comportamentos saudáveis ${ }^{401}$, e a implementação de programas de prevenção coletiva incumbe às municipalidades ${ }^{402}$. Avaliações e pesquisas para o melhor desenvolvimento de centros de assistência a drogaditos são freqüentes ${ }^{403}$, e o sistema prisional conta com mecanismos legais e órgãos que visam a estimular o interesse de internos por tratamento ${ }^{404}$.

O diploma legislativo neerlandês cardeal em matéria de controle de drogas é a chamada Lei do Ópio (“e outras substâncias narcóticas”), promulgada

401 Nesse mister, há dois diplomas legislativos particulamente relevantes: a Lei da Educação Primária e a Lei de Bases para a Educação Secundária.

402 Assim, a Lei de Prevenção Coletiva e Saúde Pública.

403 Nos termos da Lei de Qualidade de Instituição de Assistência, de 1996.

404 European Union. EMCDDA. European legal database on drugs - contry profile:

The Netherlands. Disponível em:

বhttp://eldd.emcdda.europa.eu/html.cfm/index5174EN.html\#>. Acesso em:

15/01/2009. 
originalmente em 1919 como consequiência das Convenções da Haia (1912-1914), e que em 1928 ganhou um novo texto que, em certa medida, permanece até hoje como base do controle ali empregado ${ }^{405}$.

A Lei do Ópio ${ }^{406}$ experimentou uma fundamental reforma no ano de 1976, a qual determinou a abordagem atual: consagrou-se a distinção entre substâncias, atendendo-se a recomendações de um grupo de trabalho formado em 1972 pelo governo local que sugeriu a introdução de uma escala de risco fundada em indicadores médicos, farmacológicos, psicológicos e sociológicos ${ }^{407}$. Destarte, desde a reforma de há três décadas, incorporou-se à lei a noção que separa drogas que alegadamente implicam riscos inaceitáveis das demais, pelo que a cannabis e derivados passaram a ser legalmente vistos como drogas leves, e as demais, drogas pesadas $^{408}$. Essa divisão possui notáveis reflexos sobre a medida da repressão penal destinadas a condutas afetas a cada grupo.

Parte da política nacional de drogas holandesa é descentralizada e incumbida aos municípios, como é o caso do controle sobre o incômodo público relacionado com o consumo de droga; no entanto, devem eles, naturalmente, observar as orientações estabelecidas pela política nacional, a qual limita seu campo de discricionariedade executiva e legislativa. Como regra, a formulação e execução de políticas nas municipalidades são gerenciadas por um sistema tripartite de consultas e tomada de decisões, em que têm lugar o chefe de polícia e o chefe da promotoria pública locais e o prefeito municipal $^{409}$.

As substâncias psicoativas merecedoras de controle são divididas em duas listas anexadas à Lei do Ópio: a lista I, que arrola as drogas de riscos inaceitáveis, entre as quais figuram opiáceos, cocaína, óleo de cannabis, codeína, anfetaminas e LSD, e a lista II, que compreende as demais, como a cannabis mesma, tranqüilizantes e barbitúricos.

\footnotetext{
405 Ibidem. Ac esso em: 15/01/2009.

406 O texto da lei holandesa foi consultado no idioma inglês. Disponível em: বhttp://eldd.emcdda.europa.eu/html.cfm/index5173EN.html\#>. Acesso em: $15 / 01 / 2009$.

407 lbidem. Acesso em: 15/01/2009.

408 Terminologia não oficial.

409 European Union. EMCDDA. Op. cit. Ac esso em: 15/01/2009.
} 
A lei prevê ressalvas que autorizam, em certas circunstâncias, a manipulação e administração de drogas para fins médicos, farmacêuticos e veterinários (art. 5, $\S 1$ et 2), bem como exceções a serem outorgadas pelo Ministério da Saúde Pública e Proteção Ambiental para fins comprovadamente científicos voltados ao desenvolvimento da saúde pública ou de animais (art. 8).

O mero uso de drogas na Holanda não é crime, malgrado se veja sujeito a restrições em muitos casos, como em escolas e transportes públicos ${ }^{410}$. Também a posse de pequenas quantidades de qualquer droga para consumo, embora legalmente proibida (Lei do Ópio, arts. 2 et 3), acaba por ser uma prioridade menor, o que faz com que qualquer pessoa flagrada em posse de até $0,5 \mathrm{~g}$, mesmo de droga considerada pesada, não venha a ser objeto de persecução penal ${ }^{411}$, embora a polícia deva confiscar a droga e consultar um órgão de assistência ${ }^{412}$.

Deveras, a não-punição do consumo sustenta-se na idéia de que tudo há que ser feito com vistas a evitar que usuários ingressem em subculturas criminais onde se quedariam distantes do alcance das instituições responsáveis pela prevenção e assistência ${ }^{413}$. Deste modo, prioriza-se a alocação de recursos reservados à repressão para a investigação e persecução das condutas análogas ao tráfico, especialmente quando se trate de tráfico internacional ${ }^{414}$.

Como acima indicado, a legislação penal do país em matéria de drogas assenta-se na separação dos mercados de drogas leves e pesadas - sendo que aquele basicamente é composto pela cannabis e derivados, como o haxixe -, e deve ser compreendida à luz desse princípio.

410 A competência para a regulação de tais restrições é descentralizada, não cabendo, portanto, às autoridades executiva e legislativa nacionais. A respeito: Ibidem, a cesso em: 15/01/2009.

411 Nesse sentido, o Ministério Público holandês, em consonância com a política nacional de drogas, esta belec eu diretivas em 1996, revisa da s em 2001, explic itando a desnecessidade de prisões e de criminalização secundária de usuánios em posse de pequenas quantida des de qua isquer drogas. Ibidem, acesso em: 15/01/2009. 412 Ibidem, acesso em: 15/01/2009. No que conceme à cannabis, vale mencionar que a posse de até $5 \mathrm{~g}$ não implic ará investigação ou persecução.

413 Essa noção, consagrada pela legislação e política executiva neerlandesas, também encontra guarida em práticas judiciais tendentes à despenalização verific a das em uma pluralida de de outros países.

${ }^{414}$ European Union. EMCDDA. Op. cit., acesso em: 15/01/2009. 
Assim, após a reforma legislativa de 1976, gradualmente emergiram os coffeeshops como pontos de venda de cannabis. Através de um rígido controle, tolera-se a existência de tais estabelecimentos com o escopo de afastar a população jovem, em seus experimentos com a erva, do contato com outras drogas. A venda de pequenas quantidades de cannabis remanesce tecnicamente como uma infração legal, mas é tolerada nos coffeeshops desde que observem os seguintes critérios postos pela procuradoria-geral: (i) nenhuma transação pode envolver mais de $5 \mathrm{~g}$ por pessoa; (ii) drogas pesadas não podem ser vendidas sob qualquer circunstância; (iii) drogas não podem ser objeto de propagandas; (iv) o estabelecimento não pode causar incômodo à tranqüilidade pública; (v) coffeeshops não podem comercializar bebidas alcoólicas; (vi) menores de 18 anos não podem adentrá-los, bem como não se lhes pode vender drogas em nenhuma circunstância ${ }^{415}$. Ante a inobservância de tais requisitos, pode o prefeito municipal determinar o fechamento do estabelecimento nos termos do art. 13 b da Lei do Ópio.

À parte os coffeeshops e sua regulação, considera-se a posse de drogas com fins comerciais uma infração mais grave que a produção e posse para consumo pessoal, e, portanto, merecedora de persecução. A pena máxima cominada para a posse de até 30g cannabis para os citados fins é de um mês de prisão e/ou uma multa de $€ 2300$ (art. 11, § 1 cc. §5). Quanto à posse das demais substâncias nesta modalidade, as penas chegam a um ano de prisão e multa de $€ 4500$ (art. 10, § 5). Ao seu turno, a produção e tráfico das drogas pesadas pode significar uma pena privativa de liberdade de até 8 anos, cumulada com multa que pode chegar a $€ 45000$ (art. 10, $\S 3)$.

A exportação ou importação de qualquer droga listada é considerada infração grave pela Lei do Ópio, sujeita a penas privativas de liberdade cujas previsões máximas in abstracto variam desde quatro anos, para a cannabis (art. 11, § 4), até doze anos, para as drogas pesadas (art. 10, § 4).

415 Ibidem. Acesso em: 15/01/2009. Cite-se que, em anos recentes, face a pressões de países próximos, o govemo holandês avalia a possibilidade de obstar o acesso aos coffeeshops para cidadãos estrangeiros. A respeito: O Estado do Paraná (s.a.). "UE quer unific ar penas e coordenar combate às drogas", 30/12/2003. Disponível em: «ttp://www.parana-online.com.br/editoria/mundo/news/69572/ >. Acesso em: 15/01/2009. 
Crimes patrimoniais cometidos com o fim de financiar o uso de drogas são incluídos na noção de prevenção a incômodos públicos potencialmente gerados por usuários, e tendem a merecer tratamento brando dos órgãos de repressão quando suas circunstâncias concretas denotarem uma reprovabilidade menor - isto é, pequenos valores envolvidos, ausência de colaboração criminosa, não-reincidência. Tendência igual é verificada, outrossim, em casos de vendas de pequenas quantidades de drogas com aquela mesma finalidade - especialmente se se tratar de drogas leves -, sempre havendo a possibilidade de encaminhamento do envolvido a instituições de tratamento e reabilitação ${ }^{416}$.

A legislação holandesa prevê ainda a possibilidade de assistência para usuários condenados por crimes não relacionados a drogas, permitindo a sua destinação a instituições especiais de tratamento intensivo por até dois anos consoante lei especial de 2001; a despeito do princípio de estímulo ao tratamento voluntário, ele pode ser compulsório nas hipóteses em que a toxicodependência seja causa de reiterado envolvimento do agente em fatos delituosos ${ }^{417}$.

No que respeita à práxis das agências de persecução no país, é comum que, em consonância com diretivas estabelecidas pela chefia do Ministério Público, a própria polícia decida - conquanto não detenha expressa autorização legal para tanto - por arquivar procedimentos de pouca importância. Por sua vez, aquele órgão atua com base no princípio da oportunidade (opportuniteitsbeginsel), a partir do qual estabelece as diretivas que visam a orientar igualmente o exercício funcional de seus membros e as atividades policiais. Em tais documentos apresenta, entre outras disposições, o que deva ser considerado como balizas de "pequena quantidade" de drogas para uso pessoal, a regulação dos coffeeshops e o tratamento procedimental dos delitos e infrações tuteladas pela Lei do Ópio ${ }^{418}$. Titular exclusivo da ação penal no país, o Ministério Público, com o propósito de melhor se ocupar de casos mais graves e relevantes, freqüentemente renuncia à ação quando o interesse seja

\footnotetext{
416 Ibidem. Ac esso em: 15/01/2009.

417 Conforme arts. 38m usque 38u do Código Penal, adicionados pela Lei de 21 de Dezembro de 2000.

418 European Union. EMCDDA. European legal database on drugs - contry profile: The Netherlands. Disponível em: বhttp://eldd.emcdda.europa.eu/html.cfm/index5174EN.html\#>. Acesso em: $15 / 01 / 2009$.
} 
menor $^{419}$, podendo fazê-lo condicionadamente ou não, nos termos dos arts. 167 e 242 do Código de Processo Criminal.

É possível que a Holanda seja o país europeu cujo controle de drogas é mais racional e abrangente - algo em certa medida tributável a seu pioneirismo liberalizante, que decerto permitiu, com o transcorrer do tempo, uma melhor observação de políticas preventivas e mesmo repressivas com vistas a seu aperfeiçoamento.

Assim, parecem ser providências positivas a descentralização e a coordenação do gerenciamento das políticas preventivas e de redução de riscos à saúde de usuários, bem como a manifesta preocupação com incômodos públicos potencialmente ocasionados por aqueles. No mesmo sentido, a atenção conferida a programas educacionais informativos e de incentivo à vida saudável provavelmente contribui de modo relevante a que o país, malgrado sua maior tolerância ao uso de drogas, não apresente índices superiores de consumo ou de problemas derivados do consumo em relação aos demais países europeus.

A abrangência dos programas de assistência neerlandeses é notável, e, mais que nos demais países, constata-se uma maior pretensão de que a adesão de usuários a tratamento seja voluntária, melhor se respeitando a liberdade individual conquanto se prevejam, igualmente, casos de internação compulsória na execução de uma sanção. A seu turno, a repressão menor e a inclusão entre as public nuisances de crimes patrimoniais relacionados a drogas e a pequenas vendas com fim de sustento do uso denotam a integração daqueles programas com a legislação e com a práxis da Justiça criminal. Evidencia-se uma preocupação concreta com a saúde pública e uma atuação institucional para além do mero simbolismo da norma penal.

As penas para o tráfico e condutas análogas segundo o direito holandês são, como visto, menores que aquelas atribuídas pelo direito alemão e, sobretudo, pelo direito espanhol. Malgrado a dificuldade, senão impossibilidade, de

419 Ibidem. Acesso em: 15/01/2009. A possibilidade de transação prévia à instauração de eventual ação penal é uma das modalidades de renúncia, e pode ocorrer em casos cuja pena cominada seja inferior a seis anos de privação de liberdade, mediante o pagamento de quantia não superior à multa prevista ao delito correspondente ou o cumprimento de outras condições. 
se avaliar a eficácia dissuasória de cominações penais, é certo que não se tem notícia de tal circunstância em algum momento haver causado emergência social no país. Em verdade, aqui as sanções parecem melhor atender ao primado da proporcionalidade, o que raramente ocorre nos demais países em matéria de drogas: nessa peculiar seara do direito penal, vêem-se freqüentemente penas para tipos de perigo abstrato equivalentes ou superiores àquelas previstas para o homicídio e outros tipos de dano bastante graves.

Do ponto de vista econômico, dada a consabida escassez de recursos dos sistemas de Justiça criminal em todo o mundo, resulta racional a opção por concentrar-se a repressão sobre condutas potencialmente mais danosas, deixando-se de lado a bagatela e casos de pequeno relevo - até pelo fato de a repressão penal a qualquer custo ter se revelado inútil e contraproducente perante seus fins manifestos.

A nosso ver, contudo, o critério da separação entre drogas leves e pesadas - que, de certa forma, se não pela lei, é adotado pela práxis judiciária também de outros países - afigura-se excessivamente arbitrário: não obstante os propagandistas da proibição haverem ocupado décadas tentando demonstrar uma maldade ínsita a certas substâncias, a nocividade de cada droga ainda depende fundamentalmente da forma como é utilizada, e, por outro lado, mesmo substâncias presentes em todas as listas de maior repressão, como os opiáceos, apresentam inegáveis propriedades medicinais - as quais não se sabe se já foram suficientemente exploradas. De toda sorte, no que respeita à cannabis e à sua classificação privilegiada, com efeito, nos dias de hoje evidencia-se o fato de sua ofensividade potencial ser comparável à de alimentos ordinariamente consumidos em quaisquer culturas.

Durante as mais de três décadas já passadas de sua vigência, a descriminalização das condutas do usuário resistiu às censuras impostas pelo contexto internacional de intensificação da guerra às drogas (liderada pelos EUA de Reagan e Bush) e a pressões exercidas pela ONU. Em face disso, é lícito crer que, não apenas do ponto de vista da legitimidade e humanidade, mas também do ponto de vista da eficácia preventivo-repressiva, é uma estratégia definitiva - tanto mais a partir do momento em que passa a ser, ainda que com diferenças, adotada por outros 
países. Por outro lado, esse modelo tem limitações, e, do ponto de vista lógico, cria um paradoxo irresolúvel pelo fato de um mesmo bem tornar-se lícito na demanda e ilícito na oferta.

\subsection{Itália}

O governo da Itália adotou, no início de 2008, um plano de ação desde logo previsto para ser substituído depois de um ano por novo documento que deve abarcar o quadriênio 2009-2012, em paralelo ao plano de ação comunitário europeu $^{420}$. O Plano Italiano de Ação sobre as Drogas de 2008 elegeu 66 diferentes medidas para serem implementadas ao longo do ano, agrupadas em cinco macroáreas principais: coordenação, redução da demanda, redução da oferta, cooperação internacional e informação, formação, pesquisa e avaliação ${ }^{421}$.

Já em sua introdução, vale mencionar, o documento de 2008 deixa expressa a necessidade de que venha a ser avaliado e monitorado durante todo o período de sua aplicação, visto que só assim se "permite identificar eventuais modificações necessárias às intervenções para serem sucessivamente planejadas" ${ }^{422}$.

Desde 1999, ano de sua instituição sob os auspícios do Ministério da Assistência Social, o desenvolvimento de políticas atinentes à prevenção, tratamento, reabilitação e reintegração social de usuários de psicoativos incumbe ao Observatório Nacional de Drogas. No mesmo ano, instituiu-se o Comitê Nacional de Coordenação Antidrogas e estabeleceu-se a descentralização das políticas executivas,

420 Italia. Ministero della Solidarietà Sociale. Piano italiano di azione sulle drogue, p. 05 . Disponível em: বhttp://www.emcdda.europa.eu/attachements.cfm/att_50769_EN_Italy\%20Action\% 20Plan\%202008.pdf>. Acesso em: 15/01/2009.

$421 \mathrm{lbidem}$, p. 08-32. Vale mencionar que, comparativamente aos demais países europeus até aqui analisados, a ênfase conferida pelo plano italiano à importância de políticas de redução de danos é menor; a própria expressão "redução de danos" é mencionada uma única vezentre as 51 páginas do documento (p. 43). 422 lbidem, p. 06-07. Trad. livre. 
determinando-se a transferência de $75 \%$ do pertinente orçamento nacional às regiões e províncias autônomas ${ }^{423}$.

O direito italiano em matéria de drogas baseou-se, historicamente, no princípio da não-criminalização do consumo, malgrado legislação aprovada em 1975 declarasse ilegal a posse - condicionando, desde então, a resposta estatal à quantidade da substância e à finalidade com que era possuída. Essa regulação, todavia, mereceu severas críticas da doutrina jurídica italiana durante a década e meia de sua vigência, porquanto sua aplicação concreta resultava em graves divergências na imposição de sanções ${ }^{424}$.

A aprovação, em 1990, da Lei n ${ }^{\circ}$ 162, de 26 de junho, foi seguida do Decreto Presidencial (DPR) no 309, de outubro do mesmo ano, que significou uma consolidação e revisão das normas até então vigentes em um texto único. Mais que isso, aquele diploma introduziu no direito italiano a proibição do consumo de drogas e de todas as condutas a ele relacionadas - como a posse, a aquisição e o transporte , sujeitas a multas administrativas as quais variavam, inicialmente, conforme a quantidade droga envolvida.

Após semelhantes críticas e um referendo popular, três anos depois se aprovou uma reforma na legislação, que ab-rogou o art. 72, 1 do DPR 309 e, com ele, fulminou a proibição do uso pessoal, a intervenção do juiz criminal em caso de inobservância de sanções administrativas e a concepção de uma quantidade média diária de consumo como critério determinante de posse para uso próprio ou para fins comerciais (arts. 75, 76 et 78, 1, "b" et “c"). O mero consumo, em si, deixou, então, de ser referido como infração na lei italiana vigente ${ }^{425}$.

Contudo, comportamentos como a posse, a aquisição e a importação para consumo pessoal remanescem proibidas como infrações administrativas,

${ }^{423}$ European Union. EMCDDA. European legal database on drugs - contry profile: Italy. Disponível em: বhttp://eldd.emcdda.europa.eu/html.cfm/index5174EN.html\#\&pluginMethod=eldd. countryp rofiles\&country= $=$ T\&langua ge $=i$ t $>$. Acesso em: 15/01/2009.

424 Ibidem. Acesso em: 15/01/2009. Deveras, o estabelecimento de quantidades fixas como critério diferenciador das condutas de traficante e usuánio pode levara injustiças flagrantes, como a condenação do último nas penas cominadas à conduta do primeiro.

425 Ibidem. Acesso em: 15/01/2009. 
cabendo às autoridades judiciais a verificação concreta da finalidade do ato, de que depende o correspondente tratamento administrativo ou penal ${ }^{426}$.

As substâncias controladas segundo o direito italiano (Decreto de 4 de março de 1992 e respectivas emendas) são distribuídas em seis listas: a lista I compreende opiáceos, cocaína e derivados, anfetaminas; a lista II, a cannabis e derivados; a lista III, barbitúricos altamente aditivos, hipno-sedativos; a lista IV, substâncias medicinais que causam dependência; a lista $\mathrm{V}$, preparados que contêm psicoativos; a lista VI, estimulantes. A resposta legal a atividades ilícitas varia de acordo com a classificação da substância em cada lista, sendo que as listas I e III são merecedoras de repressão mais severa que as listas II e IV.

Na primeira oportunidade em que alguém é encontrado na posse para uso próprio de drogas, a consequiência ordinária é a sua intimação para uma entrevista com o chefe de polícia local, o qual registrará a ocorrência e entregar-lhe-á um documento oficial que menciona os males potencialmente causados pela droga e formalmente adverte-lhe a não mais consumir substâncias ilegais; sempre que possível, sua família será informada a respeito e convidada a procurar serviços de assistência social e terapêutica $^{427}$. Se o fato volta a ocorrer com a mesma pessoa, sucede nova entrevista com o chefe de polícia, ora assistido por consultores dos serviços assistenciais locais, e se lhe impõe uma sanção administrativa (suspensão de direitos como porte de arma ou habilitação para conduzir veículos automotores, apreensão do passaporte, etc.). Esta sanção temporária valerá por dois meses se a substância possuída houver sido das listas II ou IV, ou quatro meses se das listas I ou III.

Nestas hipóteses, pode o indivíduo - adolescente ou adulto - solicitar a sua inscrição em serviços de tratamento ou reabilitação, o que implica a suspensão dos procedimentos administrativos supracitados até a sua avaliação após um período previamente determinado. Se, no entanto, deixa de comparecer ao programa sem justificativa válida, é convocado a nova entrevista com o chefe de polícia, que o alertará sobre as conseqüências de uma eventual segunda desistência - caso em que o

\footnotetext{
426 lbidem. Ac esso em: 15/01/2009.

427 Ademais, independentemente da classificação da substância, essa será a abordagem quando o possuidor seja um menor de 18 anos.
} 
fato será reportado ao Ministério Público, para análise e acompanhamento. Em uma eventual terceira desistência, sujeita-se o indivíduo a uma ou mais das seguintes sanções administrativas, por um período de dois a quatro meses (listas II e IV) ou três a oito meses (listas I e III): apreensão do passaporte; suspensão de porte de arma; suspensão de habilitação para dirigir; comparecimento bissemanal perante a autoridade policial; privação de visitação a locais determinados; prestação semanal de serviços à comunidade; apreensão do veículo utilizado no transporte ou armazenamento da droga; e, no caso de cidadãos extra-comunitários, suspensão da permissão de residência no país.

Sanções de natureza penal são destinadas exclusivamente à posse de drogas com o fim de obtenção de lucro, bem como às demais condutas análogas. A esses ilícitos, a legislação italiana atribui penas severas: a produção e tráfico de substâncias das listas I e III implicam penas de oito a vinte anos de privação de liberdade, mais multas de entre $€ 25000$ a $€ 250000$; se se tratar de drogas contidas nas listas II e IV, as penas variam entre dois e seis anos de prisão, e as multas, entre $€$ 2000 e $€ 77000$.

No caso de pequenas quantidades, as penas para a produção e o tráfico variam entre um a seis anos de privação da liberdade e multas de $€ 2600$ a $€ 26000$ para as listas I e III, e entre seis meses e quatro anos de prisão e multas de $€ 1000$ a $€ 10000$ para as listas II e IV.

Inexistem benefícios legais a quem comete crimes patrimoniais com o fim de sustentar seu consumo ou satisfazer sua dependência de drogas, embora, no caso do furto (Código Penal, art. 624), a exemplo do que ocorre no Brasil, as sanções podem ser bastante leves se o prejuízo resultante também o for, além de se lhe aplicarem benefícios processuais. Igualmente, não há concessões legais para casos de comercialização de drogas com o fim de sustento do hábito ou vício, embora a práxis judiciária tenda a impor a tais situações penas mais próximas das mínimas cominadas para cada fato ${ }^{428}$.

428 European Union. EMCDDA. European legal database on drugs - contry profile: Italy. 
$\mathrm{Na}$ Itália, também semelhantemente ao caso brasileiro, vige o princípio da obrigatoriedade da ação, que afasta eventual margem de discricionariedade do promotor público para arquivar casos que considere de menor interesse. O mesmo ocorre em sede policial, na medida em que cada ocorrência há que ser imediatamente relatada ao Ministério Público, que, por sua vez, havendo materialidade delitiva e indícios de autoria, tem, como visto, o dever de instaurar a persecução.

Faculta-se a usuários apenados com privação da liberdade a possibilidade de converter seu encarceramento em terapias intensivas, neste caso, porém, deve o juiz ser convencido do comprometimento do apenado ao tratamento e da adequação deste ao quadro toxicológico daquele. Deveras, medidas alternativas de tratamento em vez da mera privação da liberdade são disponibilizadas a todos, embora com variações de um caso a outro, e os serviços de assistência social e de saúde têm desempenhado um papel cada vez maior em instituições penitenciárias do país $^{429}$.

Como visto, também o direito italiano optou pela descriminalização das condutas do usuário - o qual, no entanto, remanesce sujeito a sanções administrativas. Um dado curioso do processo descriminalizador italiano é o fato de haver sido precedido de uma movimentação da opinião pública e até mesmo de um plebiscito nacional, o que indica uma notável resistência da população à imposição arbitrária do modelo criminalizador em detrimento da liberdade individual.

No que concerne ao tráfico, repetem-se as sanções desarrazoadamente elevadas, e também aqui parece faltar previsão legal diferenciadora entre o traficante-profissional e o traficante-usuário. Não obstante, seria desejável um tratamento especial para autores de crimes patrimoniais motivados pelo uso de drogas que fosse além da opção pela aplicação concreta de penas mais próximas do limite mínimo, como sucede no modelo holandês. Essas ausências tornam-se mais relevantes porquanto no direito italiano não se aplicam as margens de discricionariedade de que dispõem - e, efetivamente, utilizam-se - promotores 
alemães e holandeses para afastar o usuário de uma criminalização secundária em muitos casos despicienda, que poderia ser resolvida também através de multas administrativas e/ou da reparação de danos.

De outra parte, depreende-se dessa breve análise o caráter mais humano da abordagem não-criminalizante destinada ao usuário, que, a princípio, não haveria por que perder eficácia dissuasória se comparada às abordagens mais repressivas. Não deixa de haver controle social formalizado; porém, é positivo o fato de haver, em vez do mero conflito suscitado pela atuação das agências de repressão penal, maior espaço para diálogo entre usuários e agentes oficiais.

Se se trata de não abandonar o paradigma sancionador, a imposição de sanções administrativas parece muito mais razoável para uma conduta socialmente inócua como a posse para uso próprio - desde que não cause dano a terceiros - de substâncias psicoativas. É de se indagar, no entanto, se esse seria o paradigma mais adequado, visto que restringe a liberdade individual para proteger o usuário de si mesmo.

\subsection{Portugal}

Em Portugal, a Estratégia Nacional para a Luta contra as Drogas, datada de 1999, definiu metas gerais e vem sendo implementada pelo Plano Nacional Estratégico 2005-2012, o qual se funda em seis eixos principais de ação - sendo que os quatro primeiros apresentam explícita transcendência sobre todas as medidas pertinentes, com o que se tenciona lograr sucesso no foco aos dois últimos: coordenação; cooperação internacional; informação, pesquisa, treinamento e avaliação; revisão de ferramentas legais; redução da demanda; redução da oferta ${ }^{430}$. Particularmente acerca da redução da demanda, concedeu-se ênfase à ação em cinco sub-áreas: prevenção e dissuasão para não-usuários ou usuários ocasionais, e redução de riscos e danos, tratamento e reabilitação (sem excluir, também, a dissuasão) para

430 Portugal. Gabinete do Primeiro Ministro. Executive Summary of the National Plan against Drugs and Drug Addiction 2005-2012, p. 03-04. Disponível em: বhttp://www.emc dda.europa.eu/attachements.cfm/att_35503_EN_Portugal\%20Sum ma ry\%20Strategic \%20Plan\%202005-2012\%20Eng lish.pdf >. Ácesso em: 15/01/2009. 
usuários freqüentes ou dependentes ${ }^{431}$. O objetivo fundamental da política portuguesa repousa na redução significativa do uso de drogas pela população e dos negativos impactos sociais e à saúde pública por ele gerados ${ }^{432}$.

Há, ainda, o Plano Nacional contra Drogas e Drogadição 2005-2008, ainda não atualizado para o próximo quadriênio, que concentra foco em áreas como coordenação, cooperação internacional, informação, formação, treinamento e avaliação, redução da demanda e redução da oferta, identificando para cada qual a(s) parte(s) responsável(is) por sua execução, cronogramas de trabalho e indicadores e instrumentos de avaliação para monitorar a implementação da política planejada ${ }^{433}$.

A principal lei portuguesa em matéria de controle de drogas é o Decreto-Lei 15/93, que sofreu sucessivas modificações e foi parcialmente revogado pela Lei $30 / 2000^{434}$. Além de estabelecer crimes e penas - inclusive abarcando a lavagem de valores - (cap. III), aquele diploma clarifica muitos aspectos da política do país concernente ao assunto, como prescrições médicas, autorizações, certificações e fiscalização (cap. II), assim como aponta responsabilidades ante a prevenção e tratamento (cap. IV) e investigação criminal (cap. VI).

No que toca à prevenção, o referido Decreto-Lei cuida especialmente do envolvimento dos serviços de saúde na execução da norma. O drogadito não é considerado criminoso, mas um doente, ao qual a legislação dedica significativa atenção. Todavia, embora historicamente a lei tenha optado pelo tratamento como substitutivo da punição, a falta de estrutura física dos serviços assistenciais, muitas vezes, criou grandes filas de espera e ensejou certa tendência de aplicação de medidas punitivas em seu lugar ${ }^{435}$.

As recentes estratégias, porém, consagraram definitivamente a idéia de constituir o tratamento e reabilitação de dependentes um dos pilares fundamentais

431 lbidem, p. 04.

432 European Union. European legal database on drugs - contry profile: Portugal. Disponível em: \http://eldd .emc dda .europa.eu/html.cfm/index5174EN.html\#\&plug inMethod=eldd. countryp rofiles\&country=PT\&language $=p t>$. Acesso em: 15/01/2009.

$433 \mathrm{lbidem}$. Ac esso em: 15/01/2009.

434 Esta norma, em seu art. 28으, revogou expressamente parte do art. 400 e o art. 41 o daquela, uma vez que desc rimina lizou as conduta s a fetas a o usuário.

435 European Union. EMCDDA. Op. cit. Acesso em: 15/01/2009. 
da política de drogas portuguesa, no que foram contempladas por recentes alterações legislativas. Deste modo, substituiu-se a promotoria pública pela Comissão para a Dissuasão da Toxicodependência no acompanhamento da execução dos programas direcionadas a usuários que não tenham envolvimento em delitos violentos (DecretoLei $130-\mathrm{A} / 2001)^{436}$.

O país divide as substâncias controladas em seis listas anexadas ao Decreto-Lei 15/93 (regularmente atualizadas por outros decretos-lei), cuja classificação repercute na repressão aos ilícitos a elas relacionados: a lista I compreende opiáceos, coca e cannabis e respectivos derivados; a lista II, drogas alucinógenas, anfetaminas e barbitúricos; a lista III, preparados de substâncias controladas; a lista IV, tranqüilizantes e analgésicos; as listas V e VI, precursores.

Até julho de 2001 o consumo de drogas e a sua posse para tal fim eram considerados infrações penais para o direito português, resultando em sanções de até 3 meses de detenção ou multa - em caso de posse de quantidades mais elevadas para consumo, poder-se-ia chegar a um ano de privação da liberdade. A entrada em vigor, naquele mês, da Lei 30/2000 representou a descriminalização do uso e posse para uso de quaisquer substâncias controladas, embora haja mantido a ilicitude administrativa de tais comportamentos (arts. $1^{\circ}$ et $\left.2^{\circ}\right)^{437438}$.

Desde então, quando alguém é surpreendido na posse de determinada quantidade de substâncias psicoativas para uso próprio, inexistindo suspeitas de que possa se tratar de posse para outro fim (e.g., comércio ou tráfico), a polícia deve

436 Ibidem. Ac esso em: 15/01/2009.

$437 \mathrm{Na}$ terminologia juńdica lusa, o consumo de drogas passou a ser matéria do direito de mera ordenação social, sendo que as chamadas contra-ordenações constituem infrações de caráter administrativo, e não penal. A respeito, vide: DIAS, J orge de Figueiredo. Direito penal: parte geral. T. I. Coimbra - São Paulo: Coimbra Revista dos Tribuna is, 2007. p. 157.

${ }^{438} \mathrm{Em}$ face dessa modific ação substancial no tratamento juńdico da matéria, a lei, aprovada em outubro e promulgada em novembro do ano anterior, estatuiu um largo período de vacatio legis para que as instituições se adaptassem à nova regulação do consumo de drogas - consoante o disposto em seu art. 29o, in verbis: "A descrimina liza ção a prova da pela presente lei entra em vigor em todo o temitório nacional no dia 1 de Julho de 2001, devendo ser adoptadas, no prazo de 180 diasa contar da data da sua publicação, todas as providências regulamentares, organizativas, técnicas e financeiras necessárias à aplicação do regime de tratamento e fisca lização nela previsto". 
encaminhá-lo à sobredita Comissão para a Dissuasão da Toxicodependência local. Cabe a esta, composta por um advogado, um médico e um assistente social avaliar a situação do sujeito sob o ponto de vista do tratamento que possa merecer. Eventual imposição de sanção administrativa, conquanto possível neste momento, não é a prioridade central $^{439}$. Destarte, às autoridades responsáveis pela repressão incumbe concentrar-se no combate à oferta de drogas.

A nosso ver, importante disposição da lei lusitana acerca do consumo é a que, de forma mais clara que o fizera a legislação anterior ${ }^{440}$ garante anonimato a quem voluntariamente solicite os serviços de assistência. Tal garantia, que obsta a ilicitude administrativa e é válida inclusive perante autoridade policiais e judiciais, abrange informações não apenas quanto à natureza do eventual tratamento, mas também quanto à sua evolução (art. $3^{\circ}$ ), o que tende a emprestar maior eficácia preventiva à norma e às políticas pertinentes.

Sobre o tráfico e condutas análogas, objeto do Decreto-Lei 15/1993, cumpre assinalar que a lei portuguesa estabeleceu diversos critérios diferenciadores da resposta estatal que lhes deva corresponder. O principal deles concerne à natureza das substâncias envolvidas no delito: enquanto que as listas I a III mereceram penas privativas de liberdade que variam entre quatro e doze anos (art. $21^{\circ}$, caput), à lista IV dedicou-se penas de entre um e cinco anos de prisão (art. $\left.21^{\circ}, 4\right)$. Circunstâncias agravantes aumentam em um terço os limites mínimo e máximo (art. 24º). Outros critérios operam no caso do "traficante-consumidor" ${ }^{441}$, em que a pena se reduz a até três anos, para as listas I a III, ou um ano, para a lista IV, de privação da liberdade (art. 260); no caso do "tráfico de menor gravidade",442, as penas variam entre um a cinco anos de prisão, para as listas I a III, ou até um ano ou multa, para a lista IV (art. $25^{\circ}$ ). A associação criminosa para o tráfico e mesmo o tráfico de precursores mereceram penas severas, respectivamente de até vinte e cinco anos (art. $\left.28^{\circ}\right)$ e até

439 European Union. EMCDDA. European legal database on drugs - contry profile: Portugal. Disponível em: বhttp://eldd.emc dda.europa.eu/html.c fm/ind ex5174EN.html\#\&plug inMethod=eldd. countryprofiles\&country=PT\&language $=p t>$. Acesso em: 15/01/2009.

440 Art. 41 do Decreto-Lei 15/93, integra Imente revogado.

${ }_{441}$ Aquele que trafica exc lusivamente para sustentar seu consumo pessoal.

442 Aquele cuja conduta, segundo a noma, vê sua ilicitude reduzida ante "os meios utilizados, a modalidade ou as circunstâncias da acção, a qualidade ou a quantidade das plantas, substânciasou preparações". 
doze anos (art. $22^{\circ}$ ) de privação da liberdade. Por fim, vale citar que ao abandono de seringas também foi cominada pena de até um ano de prisão (art. $32^{\circ}$ ).

Não há, outrossim, margens de discricionariedade policial ou ministerial no tocante á persecução ${ }^{443}$.

Políticas de redução de danos, como terapias substitutivas e trocas de seringas - sendo que estas são realizadas não apenas em estabeleciemntos oficiais, mas em farmácias privadas de todo o pais -, também são consideravelmente aplicadas em Portugal $^{444}$.

Cabe assinalar que a experiência portuguesa, a qual também logrou considerável progresso ao descriminalizar as condutas do usuário, demonstra, por outro lado, a dificuldade de adaptação institucional a uma abordagem não-repressiva do assunto, na medida em que mesmo após a descriminalização houve casos em que a pretensa abordagem terapêutica converteu-se em repressão. Isso mostra, ademais, a temeridade e autoritarismo de uma abordagem excessivamente terapêutica, sobretudo se se considera que a absoluta maioria dos usuários de drogas faz-lhes uso ocasional, e não apresenta problemas patológicos ou sociais dele decorrentes.

Nesse mister, a substituição do responsável pela acusação na seara penal - o Ministério Público - por um órgão interdisciplinar com funções específicas - a Comissão para Dissuasão da Toxicodependência - no acompanhamento e avaliação de usuários em tratamento denota alteração relevante de paradigma sobre a questão do usuário, complementada pela redução do foco na imposição imediata de sanção e pelo estímulo à adesão voluntária aos programas de tratamento.

443 Importa mencionar que, a té a descrimina lização do uso havida em meados de 2001, ocasionalmente sucedia de o Ministério Público sugerir medidas altemativas de tratamento quando the parecessem mais eficazes em casos concretos que a mera repressão; porém, mesmo nestas situações, raramente se renunciava à pena ou esta era suspendida com potencial extinção posterior da punibilidade - o que foi interpretado como incoerência, à qual a edição da Lei 30/2000 também visou prevenir. A respeito: European Legal Database on Drugs. Op. cit. Acesso em: 15/01/2009.

444 RODRIGUES, Luciana Boiteux de Figueiredo. Controle penal sobre as drogas ilícitas: o impacto do proibicionismo no sistema penal e na sociedade. Tese de doutoramento apresentada à Faculdade de Direito da Universidade de São Paulo. São Paulo: 2006, p. 131. 
Quanto aos crimes e penas, merecem destaque as figuras típicas do traficante-consumidor e do tráfico de menor gravidade, que conferem, na medida do que resta possível ao direito penal de drogas, maior proporcionalidade entre circunstâncias fáticas e respectivas respostas penais.

\subsection{Reino Unido}

No início de 2008, o Reino Unido adotou a sua segunda estratégia decenal sobre o tema, denominada "Drogas: Protegendo Famílias e Comunidades" e válida até 2018. Com foco nas relações entre cidadãos e substâncias ilícitas, compreende quatro áreas principais de concentração de ações: repressão à oferta de drogas, a crimes correlatos e a comportamentos anti-sociais ${ }^{445}$; prevenção de danos a crianças, jovens e famílias afetadas ${ }^{446}$; oferecimento de novas abordagens de tratamento e reintegração social ${ }^{447}$; campanhas de informação pública, comunicação e engajamento comunitário ${ }^{448}$.

A estratégia britânica atual acompanhou-se, pela primeira vez, de um plano de ação trienal, o qual previu 86 medidas a serem implementadas até 2011. Ainda, com base na estratégia decenal do reino, a Irlanda do Norte $^{449}$, a Escócia ${ }^{450}$ e o País de Gales ${ }^{451}$ mantêm as suas próprias estratégias locais.

445 United Kingdom. Home Secretary. Drugs: protecting families and communities the 2008 drug strategy, p. 14-20. Disponível em: বhttp://www.emc dda.europa.eu/atta chements.cfm/att_50809_EN_UK\%20Strategy\% 202008-2018.pdf >. Acesso em: 15/01/2009.

$446 \mathrm{lbidem}$, p. 21-26. Acesso em: 15/01/2009.

447 Ibidem, p. 27-32. Acesso em: 15/01/2009.

448 Ibidem, p. 33-36. Acesso em: 15/01/2009.

449 . North Ireland. Department of Health, Social Services and Public Safety. New Strategic Direction for Alcohol and Drugs 2006-2011. Disponível em: বhttp://www.emcdda.europa.eu/attachements.cfm/att_50804_EN_Northem\%20lrel and\%20Stra tegy\%202006-2011.pdf $>$. Ac esso em: 15/01/2009.

450 Sc otland. Ministry for the Public Safety. The Road to Recovery: a New Approach to Tackling Scotland's Drug Problem. Disponível em: $\langle$ tttp://www.emc dda.europa.eu/attachements.cfm/att_53209_EN_Sc otla nd\%20Stra tegy\%202008.pdf>. Acesso em: 15/01/2009.

451 Wales. Ministry for Social J ustice and Local Govemment. Working together to reduce harm: the substance misuse strategy for Wales 2008-2018. Disponível em: বhttp://www.emcdda.europa.eu/attachements.cfm/att_50808_EN_Wales\%20Strate gy\%202008-2018.pdf>. Acesso em: 15/01/2009. 
Um dos mais importantes objetivos da política britânica é propiciar a quem apresente problemas relacionados a uso de drogas a manutenção de vidas saudáveis e distantes da criminalidade, estabelecendo-se metas ambiciosas para ampliar a adesão aos programas de assistência. Para o seu cumprimento criou-se a Agência Nacional de Tratamento do uso Indevido de Drogas, cujo escopo é atuar em conjunto com o Departamento do Interior e o Departamento de Saúde possibilitando acesso imediato a tratamento de alta qualidade a qualquer pessoa que dele necessite em todo o país ${ }^{452}$. Essa agência regulatória ainda tem sob sua competência a avaliação da qualidade de cada modalidade de tratamento, bem como a coordenação - e otimização - do orçamento unificado de todos os órgãos executivos encarregados do controle de drogas no país (polícias, instituições penitenciárias, governos locais e autoridades de saúde) $)^{453}$.

Deveras, no campo preventivo e de atenção à demanda, o Reino Unido é comumente lembrado por haver sido pioneiro em políticas bem sucedidas de redução de danos, que ali se intensificaram desde a década de $1980^{454}$ e vêm sendo aplicadas sem interrupções.

No decênio presente, empresta-se notável ênfase a políticas preventivas para com grupos de jovens que apresentam maior vulnerabilidade e a programas terapêuticos com foco especial sobre a redução de danos. Nesse mister, o governo britânico não exclui a possibilidade de permitir a administração médica de cannabis ou até mesmo de heroína - neste caso, como recurso para estabelecer uma ligação entre usuários da droga e terapias diversivas com uso de metadona ${ }^{455}$.

Destacada meta da estratégia britânica reside na redução drástica da reincidência de delitos cometidos por usuários. Nesse mister, desde a adoção do primeiro plano decenal em 1998, o governo tem aumentado sensivelmente os

452 European Union. EMCDDA. European legal database on drugs - contry profile: United Kingdom. Disponível em: বhttp://eldd.emcdda.europa.eu/html.cfm/index5174EN.html\#>. Acesso em: 15/01/2009.

453 Ibidem. Acesso em: 15/01/2009.

454 A respeito, vide: REG HELN, Elisângela Melo. Redução de danos: prevenção ou estímulo ao uso indevido de drogas injetá veis. São Paulo: Revista dos Tribuna is, 2002, p. 80-83.

455 European Union. EMCDDA. Op. cit. Acesso em: 15/01/2009. 
investimentos em tratamento para usuários condenados pela prática de delitos, e procurado desenvolver um rol inovador de intervenções no sistema de Justiça criminal e execuções penais para identificar usuários e oferecer-lhes assistência adequada $^{456}$. Assim, entre outras medidas, no início do atual decênio implementou-se com sucesso um programa com vistas a que todas as forças policiais tivessem, em cada cárcere do país, funcionários envolvidos em programas de assistência para drogaditos que pudessem, já desde o primeiro contato com um usuário detido por qualquer delito, encorajá-lo a ingressar em tais programas ${ }^{457}$.

Em 2000, foi promulgado novo diploma legislativo que introduziu e regulamentou a possibilidade de, ao julgar delitos cujo cometimento acredite haja sido influenciado pelo uso de drogas, a autoridade judicial impor, na sentença condenatória, obrigação de abstinência ao apenado face a drogas da classe A inclusive com a periódica e compulsória realização de exames toxicológicos para o acompanhamento de seu progresso pela autoridade judicial ${ }^{458}$. Pretende-se, deste modo, quebrar a ligação entre o usuário e a droga, para que, no longo prazo, seu contato com ela seja definitivamente perdido. Com o mesmo propósito de afastar o usuário da droga, é possível impor-se, paralelamente à obrigação de abstinência, medidas alternativas ao mero recolhimento à prisão, em uma sorte de reaproximação do usuário à comunidade conjugada com abstinência e tratamento compulsórios ${ }^{459}$.

Ao longo desta década, outrossim, a administração penitenciária da Inglaterra e País de Gales houve por disponibilizar albergues que visam a oferecer apoio intensivo nos primeiros meses de liberdade de ex-usuários apenados. Visa-se,

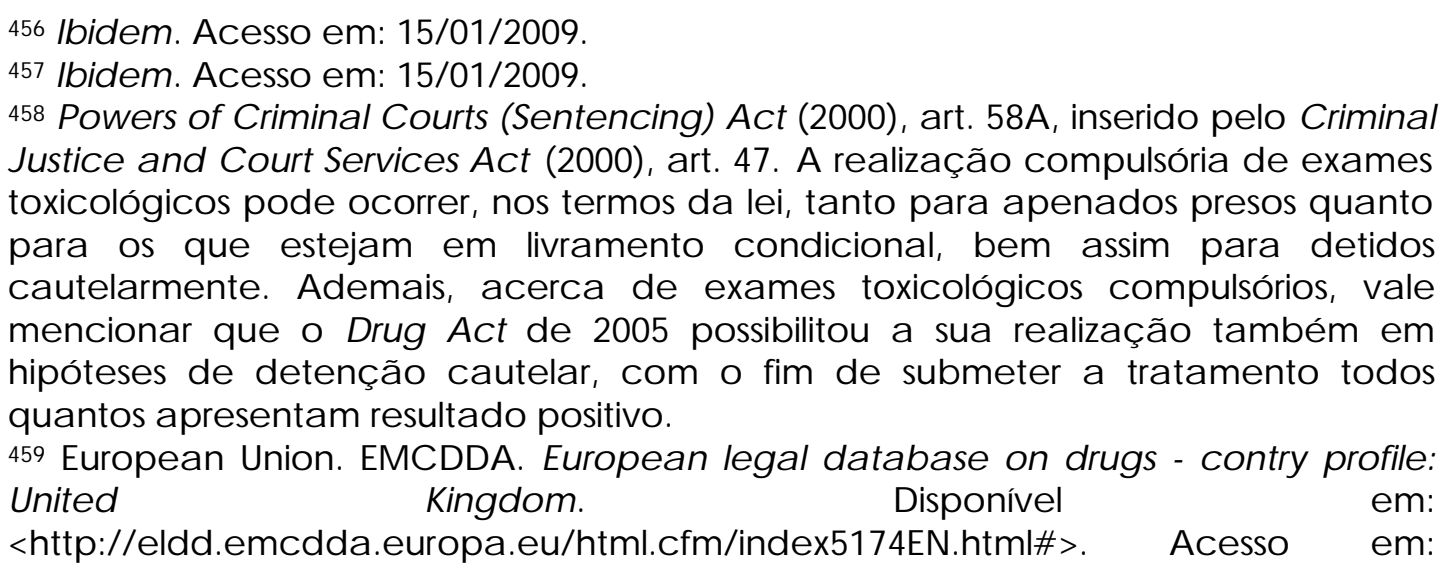
$15 / 01 / 2009$. 
destarte, a prevenir, por meio da assistência ao egresso, o retorno do contato com as drogas e uma possível reincidência delituosa ou infracional a elas relacionada ${ }^{460}$.

No campo legislativo-repressivo, convém considerar que o principal diploma legal britânico em matéria de controle de drogas é o Misuse Drugs Act (MDA), em vigor desde 1971 - alterado por muitas emendas promulgadas desde então, e complementado por outra considerável quantidade de normas. O MDA instituiu um conselho consultivo em matéria de drogas que analisa indicadores de uso indevido no reino e aconselha ministros de Estado sobre problemas sociais que derivem desse uso indevido (art. 1).

De acordo com o MDA (art. 2 cc. Schedule 2), as substâncias psicoativas controladas distribuem-se em três diferentes classes, em ordem decrescente de severidade de repressão: a classe A compreende opiáceos e derivados da coca; a classe B, anfetaminas; a classe C, cannabis $^{461}$, sedativos e barbitúricos. A regulação das substâncias também varia conforme cinco listas cujo critério diferenciador é a utilidade para fins médicos. Destarte, a lista 1 compõe-se de drogas consideradas terapeuticamente imprestáveis, e as demais seguem em ordem crescente de utilidade medicinal e decrescente de controle ${ }^{462}$.

Ainda consoante o $M D A$, a punição do consumo de drogas é feita através do modelo incriminador da posse para uso, e não do uso em si ${ }^{463}$. Distinguese a mera posse de droga controlada (art. 5.2) da posse de droga controlada com intuito de fornecimento a terceiro (art. 5.3). A resposta às infrações diferencia-se também conforme o procedimento judicial adotado, que pode ser sumário, perante a Magistrates Court, ou on indictment, perante a Crown Court. Assim sendo, a condenação sumária por posse ilegal de substâncias da classe A pode resultar em até seis meses de prisão ou multa de até £ 5000; a seu turno, condenação on indictment pode levar a penas de até sete anos de prisão e/ou multa sem limite máximo cominado. Para as drogas da classe B, a mesma conduta merece pena de até três

460 lbidem. Ac esso em: 15/01/2009.

461 A cannabisfez parte da classe B até 2004, quando foi reclassificada.

462 European Union. EMCDDA. Op. cit. Ac esso em: 15/01/2009.

463 Todavia, como exceção a essa regra, o art. 9 do MDA prevê a proibição do ato de fumar ópio - muito embora, cumpre anotar, a persecução penal de fatos subsumíveis a essa modalidade é rara na atual realida de britânica. Ibidem. Acesso em: 15/01/2009. 
meses ou cinco anos de prisão, e multa alternativa de até $£ 2500$ ou ilimitada (neste caso, alternativa ou cumulada com a privação da liberdade), respectivamente para condenações sumárias ou on indictment. Por fim, para drogas da classe C, a posse de drogas pode implicar até dois meses de prisão ou multa de até $£ 1000$ no procedimento sumário, ou até dois anos de prisão e/ou multa ilimitada no procedimento on indictment ${ }^{464}$.

Em virtude da atribuição de margens de discricionariedade ao controle executado pelos órgãos de repressão, às penas supra-aludidas adicionam-se sanções alternativas voltadas à posse para uso próprio de substâncias psicoativas, a saber: notificação informal do chefe de polícia (de que não deriva qualquer sorte de registro policial); notificação formal (em documento oficial que requer ao sujeito não repetir o comportamento para evitar conseqüências mais graves; permanece registrada apenas localmente); advertência (registrada no sistema policial global do reino) ${ }^{465}$.

A repressão ao tráfico de drogas e suas condutas análogas no Reino Unido foi determinada pelo Drug Trafficking Act, de $1994^{466}$, e, a exemplo do que sucede com a posse para consumo, varia de acordo com a classificação das drogas envolvidas (estabelecida pelo $M D A$, norma axial do controle britânico) e o procedimento e respectiva competência jurisdicional. Dessa maneira, as sanções mais severas atribuídas pelo direito britânico são aquelas para casos de competência da Crown Court, onde se realizam os procedimentos on indictment. Nessa hipótese, a pena corporal máxima para o tráfico de psicoativos da classe A repousa em prisão perpétua $^{467}$, e para substâncias da classe B, em 14 anos de privação da liberdade (MDA, Schedule 4).

Nos termos do Drug Trafficking Act, uma condenação por tráfico ou conduta análoga perante a Crown Court poderá ${ }^{468}$ acompanhar-se de uma estimativa

\footnotetext{
464 Ibidem. Acesso em: 15/01/2009.

$465 \mathrm{lbidem}$. Ac esso em: 15/01/2009.

466 Esta lei define o tráfico (arts. 1 usque 3) como qualquer produção, transporte, a mazenamento, fomecimento, exportação, importação, etc., de substâncias abrangidas pelo MDA.

467 Ainda acerca do tráfico de drogas da classe A, o Powers of Criminal Courts Act de 2000 introduziu disposição que determina uma pena privativa de liberdade mínima de sete anospara uma eventual terceira condenação nesta espécie.

468 Aparentemente, isso é o que ocorre na maioria dos casos.
} 
do lucro auferido pelo agente com o delito, para que valor correspondente seja objeto de confisco. Ao proceder a tal estimativa, permite-se às cortes estabelecer a presunção - relativa - de que todos os ativos do agente ao tempo da condenação, somado a quaisquer propriedades que tenham sido suas em algum momento dos seis anos anteriores, possam formar o proveito da atividade delituosa e, portanto, ser objeto de confisco (art. 2 cc. art. 4$)^{469}$.

Não obstante, o Criminal Justice and Police Act de 2001 conferiu às cortes britânicas o poder de impor proibições de viagens internacionais a condenados a um mínimo de quatro anos de prisão por tráfico com conexões internacionais, podendo-se apreender o passaporte de cidadãos britânicos pelo período concernente (art. 33) $)^{470}$. Com isso, tenciona-se prevenir o restabelecimento de relações com cidadãos estrangeiros que possam facilitar o trânsito internacional de substâncias ilícitas e a sua conseqüente oferta no mercado nacional ${ }^{471}$.

Quanto à práxis ordinária das agências britânicas de controle social formal ante os casos que lhes são submetidos, há que se mencionar, primeiramente, que a posse para uso pessoal de quaisquer drogas em pequenas quantidades tende a receber uma resposta leve; uma notificação ou uma advertência, a qual pode se repetir em uma segunda ou até mesmo terceira oportunidade - dependentemente de circunstâncias concretas do fato e do agente ${ }^{472}$. O fornecimento de drogas a terceiros, por sua vez, sempre implicará uma pena mais severa, ainda que subsista com o exclusivo fim de financiar o próprio consumo; entretanto, neste caso, a pena a ser imposta tende a ser mais branda que o seria para um traficante profissional. Com efeito, as penas para negociadores comerciais de substâncias proibidas tendem a ser invariavelmente severas, mormente tratando-se de grandes quantidades - hipótese

469 Outrossim, não é dema is observar que tal procedimento pode haver mesmo que não haja sido pleiteado pela acusação - bastando, apenas, que a corte 0 entenda devido (art. 2, 1, "b").

470 Nos termos do art. 33, 3, se preenchidos os requisitos para a proibição, ela deverá ser imposta por um período não inferiora dois a nosapós a soltura do a penado.

471 European Union. EMCDDA. European legal database on drugs - contry profile: United Kingdom. Disponível em: বhttp://eldd.emcdda.europa.eu/html.cfm/index5174EN.html\#>. Acesso em: $15 / 01 / 2009$.

472 lbidem. Acesso em: 15/01/2009. 
em que a natureza da droga e sua classificação tornam-se menos importantes para fins de atribuição de sanção ${ }^{473}$.

Não há estatísticas fiáveis acerca de respostas usuais das cortes britânicas em face de crimes patrimoniais cometidos com o escopo de financiar o consumo de drogas. De acordo com o EMCDDA, entrevistas indicaram que usuários preferem não revelar seu consumo por duas principais razões: (i) o fato tornar-se-ia inafiançável; (ii) sanções tenderiam a ser mais severas. Evidências concretas a esse respeito, porém, inexistem, e a única hipótese vista como abstratamente provável é a de que as cortes adicionariam à sanção o tratamento obrigatório - o que pode explicar, em certa medida, a refratividade daqueles (e, por conseguinte, uma certa contraproducência da severidade repressiva consubstanciada no afastamento de usuários de possibilidades de tratamento) ${ }^{474}$.

Como visto, o Reino Unido conta com excelente estrutura institucional do ponto de vista regulatório e de implementação e avaliação de políticas públicas sobre drogas, o que contribui para que seja visto como um dos principais modelos internacionais no que toca à prevenção e redução de danos. Combinam-se estratégias de longo prazo com planos de ação de médio prazo, estabelecendo-se metas cuja execução é permanentemente monitorada.

Mantém-se uma ampla rede de assistência social, que possibilita amplo acesso a tratamento e orientação - de que não se excluem, vale destacar, os estabelecimentos penitenciários e centros de apoio a egressos.

A legislação britânica atinente à repressão de drogas é bastante vasta e complexa. Apresenta uma gama de sanções alternativas para usuários que a situa em um modelo despenalizador das condutas deste, a exemplo do caso tedesco. No entanto, para as condutas análogas ao tráfico, institui penas gravíssimas tanto corporais quanto pecuniárias, muita vez flagrantemente desproporcionais e abusivas. Ainda, seu sistema de Justiça criminal não apenas fomenta tratamentos forçados, mas permite intervenções como a realização de exames toxicológicos compulsórios para averiguação de um detido ou avaliação do progresso de alguém sob tratamento.

473 Ibidem. Acesso em: 15/01/2009.

474 lbidem. Acesso em: 15/01/2009. 
Assim sendo, se as redes de assistência e prevenção britânicas, e mesmo a sua abordagem inicial para com usuários de drogas leves, remanescem deveras exemplares, não é possível dizer o mesmo de sua estrutura legislativa de repressão ao tráfico e condutas análogas, cujo autoritarismo não parece corresponder ao estado atual de desenvolução da axiologia do direito penal.

\subsection{Reflexões ulteriores}

Da análise dos sistemas de controle de drogas alemão, espanhol, holandês, italiano, português e britânico, ademais, ressaltam-se algumas constatações relevantes: em primeiro lugar, mesmo entre uma quantidade pequena de países, e ainda que eles se localizem próximos uns dos outros, e a despeito das próprias listas estatuídas pela ONU, não se verifica uma coerência entre as listas de controle de substâncias por eles consagradas. Excetuando-se o fato de opiáceos e derivados de coca figurarem nas listas de maior controle em todos os casos, a topologia classificatória das demais substâncias varia de um país para outro, sendo que a própria cannabis, a droga mais tolerada em diversos países como a Espanha, a Holanda e o Reino Unido, é listada entre as de máximo controle em Portugal. Este, ademais, ao lado da Itália, apresenta seis listas de psicoativos controlados, ao passo que a Holanda, apenas duas - e a Espanha abstém-se de fazê-lo. Tudo isso apenas reforça a idéia de que inexiste um critério científico universal e seguro para afirmar o que seja uma substância boa e o que seja uma substância má, o que acaba se reservando ao mero arbítrio legal - deslegitimando, também aqui, uma legislação repressiva que ainda pretende ser universal.

Ainda no que concerne às listas, note-se que, em via de regra, são elas estabelecidas em leis em sentido estrito (casos da Alemanha, Holanda, Itália, Portugal e Reino Unido). Isso previne o problema de a norma penal incriminadora ser completada por norma regulamentar ou portaria emanada do Poder Executivo caso do direito brasileiro -, conferindo-se maior segurança jurídica aos cidadãos e evitando-se maiores questionamentos acerca da conformidade, nesse particular, da figura típica com o princípio da legalidade. Não obstante, embora pudesse ser óbvio, vale lembrar que, para o direito europeu, todo rol de substâncias consideradas 
proibidas é taxativo, não se podendo impor as sanções referentes ao controle de drogas a condutas que envolvam substâncias outras, como ocorre atualmente no país modelo e propulsor do proibicionismo ${ }^{475}$.

A observação de algumas previsões legais proibitivas européias em matéria de drogas informa, ademais, que, em diversas hipóteses, inclusive quando se trate de figuras típicas de condutas análogas ao tráfico às quais se atribuem sanções bastante graves, inexiste a cominação de pena mínima, possibilitando à autoridade judicial competente impor a sanção mais condizente - e proporcional - com as circunstâncias concretas do fato. Isso porque, em matéria de repressão penal a drogas, é de amplo conhecimento que as mesmas figuras típicas podem abranger condutas de reprovabilidade real e lesividade potencial bastante díspares, como os casos do pequeno cultivador ou do pequeno operado de vendas em ruas comparados ao do grande capitalista do tráfico internacional. Nesse sentido, pois, são os casos exemplares da totalidade das incriminações da Lei do Ópio holandesa (cujas sanções vêm insertas no arts. 10 et 10a) e do MDA britânico (arts. 3 usque 6 cc. Schedule 2) ${ }^{476}$.

Deveras, quanto ao usuário, o modelo descriminalizador adotado pela Holanda e seguido por Itália, Espanha e Portugal deve prevalecer, em virtude de

475 Diante da frustração repressiva em face das drogas sucedâneas introduzidas no mercado desde os anos 80 - especialmente as designer drugs, cuja composição nem sempre poderia ser enquadrada nas listas de controle -, os EUA reagiram com a promulgação do Designer Drugs Act. Este, ao condicionar a licitude de qualquer substância à sua expressa autorização pelos órgãos regulatórios competentes, subverteu a lógica do controle penal, introduzindo o princípio de que, na peculiar seara juńdica afeta às drogas, tudo o que não é expressamente pemitido está proibido. A respeito: ESCOHOTADO, Antonio. Historia general de las drogas, 3a ed. Madrid: Espasa, 2000, p. 22; 1008-1009.

476 A respeito, porém, impende observar que a correta distribuição da J ustiça na seara criminal depende essencialmente da cultura juńdica praticada pelas autoridades judiciais, algo de que o caso brasileiro é exemplar. como se sabe, a reforma da parte geral do Código Penal, em 1984, teve como um de seus pressupostos a atribuição de poderes aos juízes para que, utilizando-se da abrangente redação do então novel art. 59, a plic assem as penas ma is a dequa das para cada hipótese concreta. Entretanto, a práxis judiciária resultou na inobservância do preceito, na medida em que freqüentemente prevalece, por um lado, a chamada "cultura da pena mínima" com que juízes se desobrigam de fundamentar eventual imposição de sanções maiores em casos que as mereceriam, e por outro, a majoração de penas com base em critérios a-técnicos como a ocorência de circunstâncias fátic as que não são ma is que elementa res do próprio tipo ou considerações de caráter ideológico. Nessa medida, o desprezo a os princípios da proporcionalida de e da igualda de na imposição das penas é gritante. 
todas as considerações históricas, sociológicas, filosóficas, criminológicas e dogmáticas que o tema comporta. Há que se avaliar, porém, qual seria a melhor regulação extrapenal do tema, ao passo que ao direito penal cabe reservar o tratamento de condutas que efetivamente possam lesionar interesses de terceiros, como o caso da condução de veículo automotor sob efeito do uso de substância psicoativa $^{477}$.

477 Exemplificativamente, veja-se o caso da reforma global do Código Penal espanhol, que, conquanto haja consagrado a descriminalização do consumo de drogas, não olvidou a tutela desse comportamento lesivo, estabelecida em seu art. 379. 


\section{REFLEXÕES CONCLUSIVAS}

Constitui o proibicionismo em matéria de drogas, desde suas origens, um modelo político-repressivo altamente segregacionista e moralista, incompatível com o atual estado evolutivo da ciência penal. Suas justificações históricas, quando desveladas, revelam-se ilegítimas, e um século inteiro de império de tal modelo parece demonstrar que se trata de uma política imprestável do ponto de vista preventivo, repressivo e pedagógico. Não se compatibiliza com a principiologia penal, nem oferece proteção à saúde pública ou mesmo à segurança pública. Ao revés, consubstancia um paternalismo estatal indevido.

Reclama investimentos infindáveis em órgãos de repressão, e resulta em cada vez maiores índices de criminalização secundária, sem, todavia, lograr a queda no consumo ou no tráfico de drogas que almeja. E, ainda, impede a execução de políticas preventivas e redutoras de danos eficazes. Ignora, portanto, a complexa dinâmica do problema a que se propõe simploriamente resolver.

Ante a notável deslegitimação - que se espera haver demonstrado nestas páginas do modelo político criminal proibicionista, e ante a sua falência como política preventiva, e feitas algumas análises de políticas que se pretendem alternativas, importa desenhar, em linhas gerais, alguma sugestão de alteração no paradigma essencialmente repressivo que ainda impera em nosso país.

Com efeito, viu-se que as políticas da proibição penal em matéria de drogas, não apresentam o desejado efeito preventivo, pelo que se impõe a busca por uma alternativa viável, mais condizente com princípios penais fundamentais e postulados constitucionais de um Estado democrático, que não cerceia a busca da alteridade nem sanciona criminalmente condutas desprovidas de ofensividade a interesses fundamentais de terceiros.

Nessa medida, o caminho a ser buscado há que ser o da descriminalização da maior parte das condutas hoje incriminadas pela Lei 11.343/06, incluindo-se aquelas insertas no art. 33, que, dadas as idiossincrasias da matéria, 
devem integrar um direito sancionador de natureza administrativa. A regulação que se pode sugerir à sua produção e comercialização seria semelhante àquela atualmente merecida por medicamentos controlados: fiscalização permanente, proibição de propaganda, controles administrativos.

Para o consumo, igualmente deve haver controles, conquanto jamais de natureza penal. Deve-se indubitavelmente restringir o consumo de drogas em locais públicos ou privados de acesso público, a exemplo da tendência atual das legislações sobre o tabaco.

Ao direito penal, então, caberiam figuras realmente relevantes, como a administração ilícita a terceiros de quantidades de drogas aptas a causar graves danos à saúde; a condução de veículo automotor sob influência do uso de psicoativos; a indução, instigação ou auxílio ao consumo danoso de crianças e adolescentes.

No que toca à prevenção, a ampla disponibilização de programas de redução de danos como trocas de seringas, terapias de substituição, salas de consumo seguro e outros deve ser objetivo central de uma política pragmática. O sistema penitenciário igualmente há que ter programas de tratamento efetivos, que, antes de impô-los, tenha mecanismos para estimular a adesão voluntária.

A consideração de aspectos socioculturais de usuários e grupos de usuários também deve ser feita, cabendo, inclusive, o recrutamento de usuários para o trabalho nos programas preventivos, como forma de incrementar o diálogo entre as instituições oficiais e os diversos grupos que compõem a sociedade.

E, fundamentalmente, o ponto de partida de toda a estratégia preventiva deve residir em programas pedagógicos voltados aos interesses de todas as faixas etárias escolares, estimulando, através de uma cultura de tolerância e responsabilidade, escolhas individuais de vida saudável.

Urgente se faz, portanto, o reconhecimento da derrota da guerra às drogas, e a conseqüente adoção de políticas jurídicas e sociais sensatas neste importante campo de intervenção estatal. 


\section{BIBLIOGRAFIA}

ANYIAR DE CASTRO, Lola. Criminologia da libertação. Trad. Sylvia Moretzson. Rio de Janeiro: Revan - Instituto Carioca de Criminologia, 2005.

ARATANGY, Lidia Rosemberg. Doces venenos: conversas e desconversas sobre drogas. São Paulo: Olho d'Água, 1991.

ARBEX JR., José. "Plano Patriota prevê nova escalada militar na Amazônia". In: Revista Pangea Mundo, 18/10/2004. Disponível [on-line] em: http://www.clubemundo.com.br/revistapangea/shownews.asp?n=241\&ed=7. Acesso em: 10/01/2009.

BARTON, Adrian. Illicit drugs: use and control. London - New York: Routledge, 2003.

BATISTA, Vera Malaguti. Difíceis ganhos fáceis: drogas e juventude pobre no Rio de Janeiro, $2^{\text {a }}$ Ed. Rio de Janeiro: Revan, 2003.

BAUM, Dan. Smoke and mirrors: the war on drugs and the politics of failure. Boston: Back Bay Books, 1997.

BECKER, Howard Saul. Outsiders: studies in the sociology of deviance. New York: The Free Press, 1997.

BERTRAM, Eva; BLACHMAN, Morris; SHARPE, Kenneth; ANDREAS, Peter. Drug war politics: the price of denial. Berkeley - Los Angeles - London: University of California Press, 1996.

BOEKHOUT VAN SOLINGE, Tim. Drugs and decision-making in the European Union. Trad. Berveley Jackson. Amsterdam: Mets \& Schilt - CEDRO, 2002.

Dealing with drugs in Europe - an investigation of European drug control experiences: France, The Netherlands and Sweden. Utrecht: Willem Pompe Institute for Criminal Law and Criminology, 2004.

BÖLLINGER, Lorenz. "Symbolic Criminal Law without limits". Disponível em: <http://www.drugtext.org/library/articles/94-const.html>. Acesso em: 15/01/2009.

BORROUGHS, William S. Junkie. New York: Ace Books, 1953. 
BOTTINI, Pierpaolo Cruz. Crimes de perigo abstrato e princípio da precaução na sociedade de risco. São Paulo: Revista dos Tribunais, 2007.

. "As Drogas e o direito penal da sociedade de risco". In : REALE JR., Miguel. Drogas: aspectos penais e criminológicos. Rio de Janeiro: Forense, 2005.

BRASIL. Secretaria Nacional Antidrogas. Cartilha sobre tabaco. Brasília: SENAD, 2005.

BRECHER, Edward M. et al. The Consumers Union report on licit and illicit drugs. Boston: Little, Brown, 1972.

BUNCE, Richard. "Social and political sources of drug effects: the case of bad trips on psychedelics". In ZINBERG, Norman E.; HARDING, Wayne M. (eds.). Control over intoxicant use: pharmacological, psychological and social considerations. New York: Human Sciences Press, 1982, pp. 105-125.

BURROUGHS, William S. Junkie. New York: Ace Books, 1953.

. Naked lunch. New York: Grove Press, 1959.

CARLINI, E. A. (superv.). II Levantamento domiciliar sobre o uso de drogas psicotrópicas no Brasil. São Paulo: CEBRID - UNIFESP, 2006.

CARVAlHO, Salo de. A Política criminal de drogas no Brasil, $4^{\mathrm{a}}$ ed. at. e ampl. Rio de Janeiro: Lumen Juris, 2007.

CARNEIRO, Henrique. Filtros, mezinhas e tríacas: as drogas no mundo moderno. São Paulo: Xamã, 1994.

CEREZO MIR, José. Derecho penal: parte general. São Paulo: Revista dos Tribunais, 2007.

CERVINI, Raúl. Os Processos de descriminalização, $2^{\mathrm{a}}$ ed. Trad. E. Granja et al. São Paulo: Revista dos Trbunais, 2002.

DAVENPORT-HINES, Richard. The pursuit of oblivion: a global history of narcotics. London - New York: W. W. Norton, 2002.

DE LA CUESTA ARZAMENDI, José Luis. "La Política criminal en materia de drogas en España, tras el nuevo Código Penal”. In: Cuadernos de derecho Judicial. Política criminal comparada, hoy y mañana. Madrid: CGPG, 1999. 
DE QUINCEY, Thomas. Confissões de um comedor de ópio. Trad. Ibañez Filho. Porto Alegre: L\&PM, 2002.

DIAS, Augusto Silva. "De que direito penal precisamos nós europeus? Um olhar sobre algumas propostas recentes de constituição de um direito penal comunitário". In: COSTA, José de Faria; SILVA, Marco A. Marques da. Direito penal especial, processo penal e direitos fundamentais: visão luso-brasileira. São Paulo: Quartier Latin, 2006, p. 335-354.

DIAS, Jorge de Figueiredo. Direito penal: parte geral, t. $1,1^{\mathrm{a}}$ ed. bras., $2^{\mathrm{a}}$ ed. port. São Paulo - Coimbra: Revista dos Tribunais - Coimbra Editora, 2007.

DÍEZ RIPOLLÉS, José Luis. A Racionalidade das leis penais - teoria e prática. Trad. Luis Regis Prado. São Paulo: Revista dos Tribunais, 2005.

DOTTI, René Ariel. Direito penal: parte geral. Rio de Janeiro: Forense, 2001.

ESCOHOTADO, Antonio. Historia general de las drogas, $3^{\mathrm{a}}$ ed. Madrid: Espasa, 2000. . Historia elemental de las drogas. Barcelona: Anagrama, 2003.

España. Ministerio de Sanidad y Consumo. Plan de Acción 2005-2008

ESTELLITA, Heloisa. "Paternalismo, moralismo e direito penal: alguns crimes suspeitos em nosso direito positivo". In: Boletim do Instituto Brasileiro de Ciências Criminais, ano 15, $\mathrm{n}$. 179. São Paulo: IBCCRIM, out/2007.

Integração regional e direito penal. Tese de doutoramento apresentada à Faculdade de Direito da Universidade de São Paulo, 2004.

FEINBERG, Joel. The Moral limits of the Criminal Law, vol. 3: Harm to self. Oxford: Oxford University Press, 1989.

FERRAJOLI, Luigi. Derecho y razón - teoría del garantismo penal, $4^{\mathrm{a}}$ ed. Trad. Perfecto Andrés Ibáñez et. al. Madrid: Editorial Trotta, 2000.

FERREIRA FILHO, Manoel Gonçalves. Direitos humanos fundamentais, $4^{\mathrm{a}}$ ed. São Paulo: Saraiva, 2000.

FREUDENMANN, Roland W.; OXLER, Florian; BERNSCHNEIDER-REIF, Sabine. "The Origin of MDMA (ecstasy) revisited: the true story reconstructed from the original 
documents". Disponível em: http://www.mdma.net/merck/ecstasy-mdma.pdf >. Acesso em: $12 / 01 / 2009$

FUCILLE, Luís Alexandre. "Plano Colômbia: o mito da militarização contra as drogas e seu impacto no plano estatal. In: Estudios politicos militares, ano 2, $\mathrm{n}^{\circ} 3$, . Santiago de Chile: Universidad Arcis, jun/2002, p. 39-54.

GALDURÓZ, José Carlos F. et al. "A Epidemiologia do consumo de substâncias psicotrópicas no Brasil: o que tem sido feito?” In: REALE JR., Miguel. Drogas: aspectos penais e criminológicos. Rio de Janeiro: Forense, 2005, p. 257-273.

GARCIA-PABLOS DE MOLINA, Antonio; GOMES, Luiz Flávio. Criminologia, $4^{\mathrm{a}}$ ed. São Paulo: Revista dos Tribunais, 2002, p. 71.

Germany. Federal Ministry of Health and Social Security. Action Plan on Drugs and Addiction

GINSBERG, Alen. "The Great marijuana boax: first manifesto to end the bringdown". In: Atlantic Monthly, Nov/1966.

GOMES, Mariângela Gama de Magalhães. "Notas sobre a inidoneidade constitucional da criminalização do porte e do consumo de drogas". In: REALE JR., Miguel. Drogas: aspectos penais e criminológicos. Rio de Janeiro: Forense, 2005.

O Princípio da proporcionalidade no direito penal. São Paulo: Revista dos Tribunais, 2003.

GONZAGA, João Bernardino. Entorpecentes: aspectos criminológicos e jurídico-penais. São Paulo: Max Limonad, 1963.

GRECO, Luís. "Tipos de autor e lei de tóxicos ou: interpretando democraticamente uma lei autoritária”. In: Revista Brasileira de Ciências Criminais, ano 11, n. 43. São Paulo: Revista dos Tribunais, abr-jun/2003.

___ " "Princípio da ofensividade' e crimes de perigo abstrato: uma introdução ao debate sobre o bem jurídico e as estruturas do delito". In: Revista Brasileira de Ciências Criminais, $n^{\circ}$ 49. São Paulo: Revista dos Tribunais, jul-ago/2004, pp. 89-147.

GRECO FILHO, Vicente. Tóxicos: prevenção - repressão, 11ª ed. São Paulo: Saraiva, 1996. 
GUÁQUETA, Alexandra. "Transformación y efectos de la cooperación antidrogas entre Colombia y Estados unidos (1970-2000)". In: CAMACHO GUIZADO, Álvaro. Narcotráfico: Europa, EEUU, América Latina. Barcelona: Obreal - Universitat de Barcelona, 2007.

GUZZI, André Cavalles. As Relações EUA - América Latina: medidas e conseqüências da política externa norte-americana para combater a produção e o tráfico de drogas ilícitas. Dissertação de mestrado apresentada ao programa inter-institucional de relações internacionais San Tiago Dantas (PUC-SP - Unesp - Unicamp). São Paulo: 2008.

HASSEMER, Winfried. "Derecho penal simbólico y protección de bienes jurídicos". Trad. Elena Larrauri. In: Pena y Estado, n. 1. Barcelona: P.P.U, sept.-dic/1991.

Direito penal libertário. Trad. Regina Greve. Belo Horizonte: Del Rey, 2007

HIRSCH, Hans Joachim. "Acerca del estado actual de la discusión sobre el concepto de bien jurídico". Trad. Daniel R. Pastor. In: Acta del Congreso Internacional de la Facultad de Derecho de la UNED. Modernas tendencias en la ciencia del derecho penal y en la criminología. Madrid: Universidad Nacional de Educación a Distancia, 2000.

HOBSBAWM, Eric John. Era dos extremos: o breve século XX. Trad. Marcos Santarrita. São Paulo: Cia. das Letras, 1995.

HOMERO, Odisséia. Trad. Manuel O. Mendes. São Paulo: Edusp, 1996.

HORMAZÁBAL MALARÉE, Hernán. “Consecuencias político criminales y dogmáticas del principio de exclusive protección de bienes jurídicos”. In: PÉREZ ÁLVAREZ, Fernando (ed.). Serta - in memorian Alexandri Baratta. Salamanca: Ediciones Universidad Salamanca, 2004.

HOUAISS, Antônio; VILLAR, Mauro de Salles. Dicionário Houaiss da língua portuguesa, $1^{\text {a }}$ reimpr. Rio de Janeiro: Objetiva, 2004.

"Inside dope: the unstoppable economics of a booming process". In: Forbes. New York: Forbes, 28/10/2003.

Italia. Ministero della Solidarietà Sociale. Piano italiano di azione sulle drogue. 
JAKOBS, Günther. ¿Qué protege el derecho penal: bienes jurídicos o la vigencia de la norma?. Mendoza: Ediciones Jurídicas Cuyo, 2001.

KARAM, Maria Lucia. De Crimes, penas e fantasias, $2^{\mathrm{a}}$ ed. Rio de Janeiro: Luam, 1993.

KHEMANI, Rughvir Shyam; SHAPIRO, Daniel M. Glossary of industrial organisation economics and Competition Law. Paris: OECD Directorate for Financial, Fiscal and Enterprise Affairs, 2002.

KUZYEMKO, Ilyana; LEVITT, Steven David. "An empirical analysis of imprisioning drug offenders". In: Journal of Public Economics, n. 88.

LABATE, Beatriz Caiuby; GOULART, Sandra Lucia (orgs.). O Uso ritual das plantas de poder. Campinas: Mercado de Letras, 2005.

LEWANDOWSKI, Enrique Ricardo. Globalização, regionalização e soberania. São Paulo: Juarez de Oliveira, 2004McALLISTER, William B. Drug diplomacy in the twentieth century. New York: Routledge, 2000.

McGLOTHLIN, William H. "Toward a rational view of hallucinogenic drugs". In: Journal of psychedelic drugs, vol. I, issue I. San Francisco: Haight-Ashbury, summer/1967, pp. 99111.

MENDES,Gilmar Ferreira; COELHO, Inocêncio Mártires; BRANCO, Paulo Gustavo Gonet. Curso de direito constitucional. São Paulo: Saraiva, 2007.

MILL, John Stuart. On Liberty and other essays. Oxford: Oxford University Press, 1991.

MODESTO, Luiz Sergio. As Drogas do Estado. Tese de doutoramento apresentada à Faculdade de Direito da Universidade de São Paulo. São Paulo: FDUSP, 2004.

MUÑOZ CONDE, Francisco. Direito penal e controle social. Trad. Cíntia Toledo Miranda Chaves. Rio de Janeiro: Forense, 2005.

Introducción al derecho penal. Barcelona: Bosch, 1975.

NEUMAN, Elías. La Legalización de las drogas, $3^{\mathrm{a}}$ ed. reestruct. e ampl. Buenos Aires: Editorial Universidad, 2005. 
ORGANIZAÇÂO MUNDIAL DE SAÚDE. Neurociência do uso e dependência de substâncias psicoativas. Geneva: OMS, 2004.

PASCHOAL, Janaína Conceição. "A Importância do encontro sobre drogas: aspectos penais e criminológicos". In: REALE JR., Miguel. PASCHOAL, Janaína Conceição. Drogas: aspectos penais e criminológicos - primeiro encontro de mestres e doutores do Departamento de Direito Penal da Faculdade de Direito da USP. Rio de Janeiro: Forense, 2005.

. Constituição, criminalização e direito penal mínimo. São Paulo: Revistas dos Tribunais, 2003.

PITOMBO, Antonio Sérgio Altieri de Moraes. Lavagem de dinheiro: a tipicidade do crime antecedente. São Paulo: Revista dos Tribunais, 2003.

POLAINO NAVARRETE, Miguel. Derecho penal - parte general, t. II. Barcelona: Bosch, 2000 .

Portugal. Gabinete do Primeiro Ministro. Executive Summary of the National Plan against Drugs and Drug Addiction 2005-2012

PRADO, Luiz Regis. Bem jurídico-penal e Constituição, $3^{\mathrm{a}}$ ed. rev., atual. e ampl. São Paulo: Revista dos Tribunais, 2003.

Curso de direito penal brasileiro, vol. $1,7^{\mathrm{a}}$ ed. rev., atual. e ampl. São Paulo: Revista dos Tribunais, 2007.

Curso de direito penal brasileiro, vol. 3, $4^{\mathrm{a}}$ ed. rev., atual. e ampl. São Paulo: Revista dos Tribunais, 2006.

REALE JR., Miguel. Drogas: aspectos penais e criminológicos. Rio de Janeiro: Forense, 2005. . Instituições de direito penal, vol I. Rio de Janeiro: Forense, 2002. Teoria do delito, $2^{\text {a }}$ ed. rev. São Paulo: Revista dos Tribunais, 2000.

REGHELIN, Elisangela Melo. Redução de danos: prevenção ou estímulo ao uso de drogas injetáveis. São Paulo: Revista dos Tribunais, 2002. 
RODRIGUES, Luciana Boiteux de Figueiredo. Controle penal sobre as drogas ilícitas: o impacto do proibicionismo no sistema penal e na sociedade. Tese de doutorado apresentada na Faculdade de Direito da Universidade de São Paulo. São Paulo, 2006.

RODRIGUES, Thiago. Política e drogas nas Américas. São Paulo: Educ - Fapesp, 2004, $334 \mathrm{p}$.

ROXIN, Claus; ARZT, Gunther; TIEDEMANN; Klaus. Introdução ao direito penal e ao direito processual penal. Trad. Gercélia B. de Oliveira Mendes. Belo Horizonte: Del Rey, 2007.

SANTOS, Juarez Cirino. Direito penal - parte geral. Curitiba: ICPC; Lumen Juris, 2006.

SHECAIRA, Sérgio Salomão. Criminologia. São Paulo: Revista dos Tribunais, 2004.

SILVA, José Geraldo da. Leis penais especiais anotadas, $3^{\text {a }}$ ed. Campinas: Millenium, 2002.

SILVA SÁNCHEZ, Jesús-María. A Expansão do direito penal: aspectos da política criminal nas sociedades pós-industriais. Trad. Luiz Otavio de O. Rocha. São Paulo: Revista dos Tribunais, 2002.

SILVEIRA, Renato de Mello Jorge. Direito penal supra-individual: interesses difusos e coletivos. São Paulo: Revista dos Tribunais, 2003.

. "Novas considerações quanto à proteção penal da saúde pública". In: Ciências Penais, ano 1, n. 0. São Paulo: Revista dos Tribunais, 2004.

Direito penal econômico como direito penal de perigo. Sâo Paulo: Revista dos Tribunais, 2006.

SNEDEN, Albert T. "Alkaloids". Disponível [on-line] em: http://www.people.vcu.edu/ asneden/alkaloids.htm. Acesso em: 13/09/2004.

TAFFARELlO, Rogério Fernando. Da Legalização das drogas como instrumento de política criminal. Tese de láurea apresentada à Faculdade de Direito da Universidade de São Paulo. São Paulo: FDUSP, 2004.

__ _ "Breve estudo acerca da atuação das instâncias de controle social formal e informal.” In: Ultima ratio, ano 1, n. 1. Rio de Janeiro: Lumen Juris, 2007. 
TAVARES, Juarez. Teoria do injusto penal, $2^{\mathrm{a}}$ ed. Belo Horizonte: Del Rey, 2002.

“THE NEW PUBLIC ENEMY N 1”. Time Magazine, 28/06/1971. Disponível [on-line] em: http://www.time.com/time/magazine/article/0,9171,905238-1,00.html. Acesso em: 10/01/2009.

TOCQUEVILlE, Alexis de. De la démocratie en Amérique, t. I, 12ª ed. Paris: Pagnerre, 1848.

TOLEDO, Francisco de Assis. Princípios básicos de direito penal, $5^{\mathrm{a}}$ ed., $7^{\mathrm{a}}$ tir. São Paulo: Saraiva, 2000.

"Treatment of malaria - a brief history of antimalarials". Disponível [on-line] em: http://www.mmv.org/pages/content_frame.asp?ThePage=page1_000400010002_1.htm\&Nav $=000400010002$. Acesso em: 13/09/2004.

United Kingdom. Home Secretary. Drugs: protecting families and communities - the 2008 drug strategy.

VON HIRSCH, Andrew. "Paternalismo direto: autolesões devem ser punidas penalmente?". Trad. Helena Regina Lobo da Costa. In: Revista Brasileira de Ciências Criminais, n. 67. São Paulo: Revista dos Tribunais, jul-ago/2007.

WISOTSKY, S. Beyond the war on drugs: overcoming a failed public policy. Buffalo - New York: Prometheus Books, 1990.

WORLD HEALTH ORGANIZATION. WHO Global status report on alcohol 2004. Geneva: World Health Organization, 2004.

ZAFFARONI, Eugenio Raúl; BATISTA, Nilo; ALAGIA, Alejandro; SLOKAR, Alejandro. Direito penal brasileiro, vol. I, $2^{\mathrm{a}}$ ed. Rio de Janeiro: Revan, 2003.

ZAFFARONI, Eugenio Raúl; PIERANGELI, José Henrique. Manual de direito penal brasileiro - parte geral, $5^{a}$ ed. rev. e atual. São Paulo: Revista dos Tribunais, 2004.

\section{Websites consultados:}

http://www.cebrid.epm.br 
http://www.cesifo-group.de

http://www.druglibrary.org

http://www.emcdda.eu.int

http://www.incb.org/

http://www.mre.gov.br

http://www.mdma.net

http://www.neip.info

http://www.oecd.org

http://www.oxfordscholarship.com

http://pricetheory.uchicago.edu

http://www.time.com

https://www.unodc.org

http://www.who.int 